\title{
Debris-flow monitoring and warning: review and examples
}

\author{
Marcel Hürlimann ${ }^{1}$, Velio Coviello ${ }^{2}$, Coraline Bel $^{3}$, Xiaojun Guo ${ }^{4}$, Matteo Berti ${ }^{5}$, Christoph Graf ${ }^{6}$,
} Johannes Hübl $^{7}$, Shusuke Miyata ${ }^{8}$, Joel B. Smith ${ }^{9}$, Hsiao-Yuan Yin ${ }^{10}$

${ }^{1}$ Department Division of Geotechnical Engineering and Geosciences, Department of Civil and Environmental Engineering UPC BarcelonaTECH, Barcelona, Spain

${ }^{2}$ Faculty of Science and Technology, Free University of Bozen-Bolzano, Italy

${ }^{3}$ Université Grenoble Alpes, Irstea, UR ETNA, St-Martin-d'Hères, France

${ }^{4}$ Key Laboratory of Mountain Surface Process and Hazards/Institute of Mountain Hazards and Environment, Chinese Academy of Sciences, Chengdu, China

${ }^{5}$ Dipartimento di Scienze Biologiche, Geologiche e Ambientali, Università di Bologna, Bologna, Italy

${ }^{6}$ Swiss Federal Institute for Forest, Snow and Landscape Research WSL, Birmensdorf, Switzerland

${ }^{7}$ Institute of Mountain Risk engineering, Department of Natural Hazards and Civil Engineering, University of Natural Resources and Life Sciences (BOKU), Vienna, Austria

${ }^{8}$ Disaster Prevention Research Institute, Kyoto University, Takayama, Japan

${ }^{9}$ U.S. Geological Survey, Landslide Hazards Program, Geologic Hazards Science Center, Golden, USA

${ }^{10}$ Soil and Water Conservation Bureau, Council of Agriculture, Nantou, Taiwan

\begin{abstract}
.
Debris flows represent one of the most dangerous types of mass movements, because of their high velocities, large impact forces and long runout distances. This review describes the available debris-flow monitoring techniques and proposes recommendations to inform the design of future monitoring and warning/alarm systems. The selection and application of these techniques is highly dependent on site and hazard characterization, which is illustrated through detailed descriptions of nine monitoring sites: five in Europe, three in Asia and one in the USA. Most of these monitored catchments cover less than $\sim 10 \mathrm{~km}^{2}$ and are topographically rugged with Melton Indices greater than 0.5 . Hourly rainfall intensities between 5 and $15 \mathrm{~mm} / \mathrm{h}$ are sufficient to trigger debris flows at many of the sites, and observed debris-flow volumes range from a few hundred up to almost one million cubic meters. The sensors found in these monitoring systems can be separated into two classes: a class measuring the initiation mechanisms, and another class measuring the flow dynamics. The first class principally includes rain gauges, but also contains of soil moisture and pore-water pressure sensors. The second class involves a large variety of sensors focusing on flow stage or ground vibrations and commonly includes video cameras to validate and aid in the data interpretation. Given the sporadic nature of debris flows, an essential characteristics of the monitoring systems is the differentiation between a continuous mode that samples at low frequency ("non-event mode") and another mode that records the measurements at high frequency ("event mode"). The event detection algorithm, used to switch into the "event mode" depends on a threshold that is typically based on rainfall or ground vibration. Identifying the correct definition of these thresholds is a fundamental task not only for monitoring purposes, but also for the implementation of warning and alarm systems.
\end{abstract}

Keywords: debris flow; monitoring; sensor; hazard; warning 


\section{Introduction}

Debris flows represent an important natural hazard and the correct understanding of the associated mechanisms is essential for adequate mitigation of their impacts on both infrastructure and society (Jakob and Hungr, 2005). Herein, we use the term "debris flow" as defined by Hungr et al. $(2001,2014)$, that is a "very rapid to extremely rapid flow of saturated nonplastic debris in a steep channel" (Hungr et al., 2001, p. 231). Typical features of debris flows are the non-Newtonian flow behaviour, a steep bouldery snout, inverse grading of the deposit, a lateral leveed path, a large potential for sediment entrainment, high flow velocity, and a peak discharge that can greatly exceed the peak discharge of debris floods or hyperconcentrated flows (Iverson, 1997; Jakob and Hungr, 2005; Takahashi, 2019).

Collectionof field measurements by in situ monitoring is a fundamental task in debris-flow research, since these data are necessary to: i) improve the knowledge of initiation mechanisms and flow dynamics (e.g., Berti et al., 1999; McArdell et al., 2007; McCoy et al., 2010; Abancó et al., 2016; Bel et al., 2017); ii) develop, calibrate and validate numerical models (e.g., Rickenmann et al., 2006; Frank et al., 2017; Vagnon et al., 2018); and, iii) design and implement warning or alarm systems (e.g., Badoux et al., 2009; Arattano et al., 2015; Berenguer et al., 2015).

In this review, we primarily focus on monitoring systems that have been developed for debris-flow research, although some of the sites are equipped with warning and/or alarm capabilities. Research monitoring systems are designed to systematically observe different parameters to improve the understanding of targeted processes. In contrast, warning or alarm systems are designed to emit timely and meaningful information to reduce stakeholders' risks associated with a debris-flow event.

Regardless of research or warning intentions,, many monitoring systems have been installed worldwide, and the number of existing sites has grown significantly in the last 20 years. Some documented examples from Europe include seven sites in Italy (Berti et al., 2000; Marchi et al., 2002; Scotton et al., 2011; Comiti et al., 2014; Coviello et al., 2015; Gregoretti et al., 2016), more than eight in Switzerland (e.g., Hürlimann et al., 2003; McArdell et al., 2007; Badoux et al., 2009), two in Austria (Hübl and Kaitna, 2010), two in France (Navratil et al., 2012), and three in the Pyrenees (Hürlimann et al., 2014; Palau et al., 2017). In Asia, Taiwan has 21 permanent monitoring sites, 3 mobile monitoring cars, and 17 portable stations (Yin et al., 2011). There are several systems installed in Japan, (Imaizumi et al., 2005; Ikeda and Hara, 2003; Takeshi, 2011; Osaka et al., 2014) including the Kamikamihori monitoring system at Mount Yakedake, which started more than four decades ago and has collected data from almost 100 debris-flow events. Similarly, the Dongchuan debrisflow observation and research station in the Jiangjia gully, China, was installed in 1961 and provides a uninterrupted time-series record of debris-flow activity (Zhang, 1993; Cui et al., 2005). Additionally, new monitoring research sites were installed in China following the Wenchuan earthquake (Cui et al., 2018). In the USA, there are two permanent monitoring systems (Coe et al., 2008), and several temporary systems monitoring debris flows within wildfire-affected watersheds (e.g., Kean et al., 2011).

Similar to these debris-flow monitoring systems, lahar-monitoring systems are situated at many volcanoes around the world. There are examples from Indonesia (Lavigne et al., 2000), New Zealand (Cole et al., 2009), the USA (Allstadt et al., 2018), and Mexico (e.g., Capra et al., 2018). In South America, several examples of hydrological or seismological monitoring networks are also employed for lahar characterization (Kumagai et al., 2009; Worni et al., 2012). Indeed, some available debris-flow monitoring techniques, like those associated with ground vibrations, grew out of lahar detection systems on volcanoes. Useful contributions to debris-flow monitoring practice have been derived from previous work in the Philippines, Indonesia, Japan, New Zealand, and the USA (e.g., Bautista et al., 1986; Pierson, 1986; Marcial et al., 1996; Sherburn and Bryan, 1999; Suwa et al., 2011). 
Three notable review papers on debris-flow monitoring have been published (LaHusen, 2005; Arattano and Marchi, 2008; Hübl and Mikoš, 2018). LaHusen (2005) provided an overview of the instrumentation used to sense debris-flow “antecedents" (precipitation, snow depth, soil moisture, water level, pore pressure) and "dynamics" (flow depth, flow velocity, ground vibration, basal stress, impact force). LaHusen also discussed considerations for power system design and data acquisition system selection, two critical components of any monitoring system. Arattano and Marchi (2008) focus their review on the description of the sensors commonly employed for debris-flow monitoring, including recommendations about data analysis techniques and details on the use of these sensors as warning devices. Hübl and Mikoš (2018) described available sensors used in debris-flow monitoring systems and presented guidelines for data recording, transmission, and archival. They also provided a list of active monitoring systems in Europe and described the role of instrumentation in early warning systems. In addition to these reviews, Itakura et al. (2005) presented a list of about 70 research papers related to debris-flow monitoring, providing information sources related to warning, prediction, and modelling.

Technological development has rapidly advanced during the last decade, as well as the conceptual advancements brought by former debris-flow research, making the implementation of monitoring devices for research, early warning and alarm purposes more and more attractive. The main goal of this paper is to present an updated and extensive review of methods and sensors for debris-flow monitoring, as well as other considerations when designing monitoring systems, such as, technical and field constraints and the different processes that influence the mobilization of debris flows. In the first part of the paper, the different sensors and monitoring techniques are presented and discussed. In the second part, nine monitoring sites from around the world are described as examples of current best practice. Following the instrumental and site descriptions, , some general data from the monitoring sites are presented and compared. Finally, we give some recommendations for the configuration of future debris-flow monitoring systems and the implementation of the data in warning systems.

\section{Systems and sensors}

\subsection{General aspects}

Many different sensors can be employed to measure the relevant physical parameters relevant for debris flows. A summary of the principal characteristics of the most common sensors are listed in Table 1, and detailed descriptions are given in the following sections. Herein, we focus on monitoring systems and sensors that are both permanently installed inside or near the catchment and are suitable for collecting high-frequency data. Therefore we do not take into account the various geomatic and remote sensing techniques used for landslide detection, mapping, and ground-surface monitoring; although important advances have been achieved in recent years by techniques, such as radar interferometry (Antonello et al., 2004; Catani et al., 2014), laser scanning (Bremer and Sass, 2012), and digital photogrammetry using unmanned aerial vehicles (UAV). In particular, the structure from motion technique combined with UAV photography allows a high-resolution reconstruction of the topography (de Haas et al., 2014; Cook, 2017), which has enormously improved our ability to characterize the landscape and geomorphic changes over time (Cucchiaro et al., 2018). All these techniques, however, are not yet suitable for real-time or near-real time monitoring of fast-moving landslides such as debris flows.

Some of the currently available sensors have originally been used for flume experiments (e.g., Iverson et al., 2010,2011) and have then been scaled up for in situ monitoring. Load plates, laser stage or entrainment sensors are only some sensors that have undergone this transformation. 
An important difference between debris-flow monitoring and the monitoring of slow-moving landslides (e.g., Coe et al., 2003; Corominas et al., 2005) is the fact that the former mostly distinguishes a low-frequency recording mode (herein called "non-event mode") from a high-frequency mode ("event mode"). This switch between the two modes is necessary because of the irregular occurrence of debris flows and the limitations of both data communication and storage.

Table 1: Principal characteristics of the most commonly used sensors for debris-flow monitoring. Information on the measured parameters, the process analysed, the spatial extent, the installation distance between sensor and active channel, and their cost in Euro (order of magnitude; cost of installation is not included) is provided.

\begin{tabular}{|l|l|l|l|l|l|}
\hline Sensor & Parameter & Process & Spatial extent & $\begin{array}{l}\text { Distance } \\
(\mathbf{m})\end{array}$ & $\begin{array}{l}\text { Cost } \\
(\mathbf{(})\end{array}$ \\
\hline Rain gauge & Rainfall, precipitation & Initiation & $\begin{array}{l}\text { Channel reach - } \\
\text { catchment }\end{array}$ & $1-100$ & $10^{2}$ \\
\hline $\begin{array}{l}\text { Time / Frequency Domain } \\
\text { Reflectometry (TDR / FDR) }\end{array}$ & Soil water content & Initiation & Cross section & $0-100$ & $10^{2}$ \\
\hline Tensiometer & $\begin{array}{l}\text { Negative pore water } \\
\text { pressure }\end{array}$ & Initiation & Cross section & $0-100$ & $10^{2}$ \\
\hline Pressure sensor & $\begin{array}{l}\text { Positive pore water } \\
\text { pressure }\end{array}$ & $\begin{array}{l}\text { Initiation/ } \\
\text { flow dynamics }\end{array}$ & Cross section & $0-100$ & $10^{2}$ \\
\hline Video camera & $\begin{array}{l}\text { Flow regime, flow } \\
\text { magnitude, surface } \\
\text { velocity etc. }\end{array}$ & $\begin{array}{l}\text { Initiation/ } \\
\text { flow dynamics }\end{array}$ & Channel-reach & $1-100$ & $10^{3}$ \\
\hline Stage sensor & Flow depth & Flow dynamics & Cross section & 0 & $10^{3}$ \\
\hline Geophone & Ground vibration & Flow dynamics & $\begin{array}{l}\text { Channel section - } \\
\text { channel reach }\end{array}$ & $1-100$ & $10^{2}$ \\
\hline Seismometer & Ground vibration & Flow dynamics & $\begin{array}{l}\text { Channel section - } \\
\text { catchment }\end{array}$ & $1-1000$ & $10^{3}$ \\
\hline Infrasound sensor & Air pressure fluctuation & Flow dynamics & $\begin{array}{l}\text { Channel reach - } \\
\text { catchment }\end{array}$ & $1-1000$ & $10^{3}$ \\
\hline Doppler radar & Surface velocity & Flow dynamics & Channel reach & $1-100$ & $10^{4}$ \\
\hline Entrainment sensor & Erosion & Flow dynamics & Cross section & 0 & $\left(10^{2}\right) 10^{3}$ \\
\hline Load cell & $\begin{array}{l}\text { Basal, lateral and } \\
\text { impact stress }\end{array}$ & Flow dynamics & Cross section & 0 & $10^{3}$ \\
\hline
\end{tabular}

\subsection{Precipitation monitoring}

Rainfall, sometimes combined with snowmelt, is the primary factor triggering most debris flows (Wieczorek and Glade, 2005). Accurate rainfall data are crucial for early warning, as well as for defining rainfall thresholds and for predicting debris-flow volume (Nikolopoulos et al., 2014; Marra et al., 2016). The most common device used for measuring rainfall is the tipping bucket rain gauge. Standard tipping-bucket rain gauges have a resolution of 0.1 to $0.5 \mathrm{~mm}$ per tip and provide simple and inexpensive rainfall measurements. However, there are some factors to consider that may affect the reliability of rainfall data obtained from these gauges. The first and most important factor is the location of the rain gauge. Many debris flows are triggered by locally intense convective rainfall characterized by a very small storm cell (a few kilometers or even less across; Underwood et al., 2016). Therefore, it is important to install the rain gauge as close as possible to the initiation zone to avoid misrepresenting the triggering rainfall conditions. Other errors include losses due to wind and sampling errors at high rainfall rates that occur when the bucket cannot tip fast enough to collect rainwater (Habib et al., 2001). Wind loss and rainfall rate errors can be substantial in debris-flow monitoring, but they can be detected and minimised by applying correction factors to actual field data (Michelson, 2004). For this reason, it can be useful to install an anemometer beside the rain gauge to measure wind speed and direction. Several studies also suggest 
that the interaction between topography and the wind-driven precipitation field is an important control for landslide triggering (e.g., Rulli et al., 2007).

In catchments with significant snowfall, an additional governing factor for debris-flow triggering may be snowmelt (Badoux et al., 2009; Hürlimann et al., 2010; Mostbauer et al., 2018). Rain gauges used in debris-flow monitoring systems are normally unheated, but in snowmelt situations a heating system might be needed. Moreover, air temperature and snow cover depth should also be monitored as debris flows can be triggered by warm rainfall on snowpack (e.g., Mostbauer et al., 2018). Snowfall lysimeters or ultrasonic/laser snow depth sensors provide reliable snow depth readings (LaHusen, 2005).

Data from weather radars provide complementary information on precipitation that can be included in an analysis of initiation conditions (e.g., Marra et al. 2014; Abancó et al. 2016). Local or even mobile Doppler radars have been used recently at some sites (Yin et al., 2011). However, radar reflectivity is an indirect measure of precipitation and data must be validated. Ground truth verification is typically provided by rain gauges, but this carries the assumption their data are accurate. Despite the continuous improvement of radar technology and calibration algorithms, predictions based on realtime monitoring of rainfall by radar is still problematic for debris-flow applications. Nevertheless, the use of weather radars may be especially valuable in specific areas such as active volcanos, where no rain gauges are available (e.g., Syarifuddin et al., 2017).

\subsection{Sensors measuring debris-flow initiation}

Debris flows are triggered by a variety of different initiation mechanisms such as shallow landslides, runoff onto unconsolidated soil, in-channel mobilization, dam failure, seismic liquefaction, rapid snow melting (Jakob and Hungr, 2005; Takahashi, 2019). In the following sections, we describe systems and sensors distinguishing between two main initiation mechanisms: i) debris flows initiated by landslides, and ii) debris flows initiated by channel runoff. In the first case, the failed mass transforms into a flow by high pore-fluid pressure induced liquefaction (Iverson et al., 1997; Bogaard and Greco, 2016). In the second case, the mechanisms are less understood, but they can involve grain-by-grain sediment bulking, or failure of the channel bed sediment (Kean et al., 2013).

\subsubsection{Debris flows initiated by landslides}

Monitoring of debris flows initiated by landslides focuses on the measurement of both pore water pressures and water content inside the slope. Landslide-triggered debris flows often involves the failure of a colluvial soil layer overlying the bedrock on a steep slope (Iverson et al., 1997; Savage and Baum, 2005). In these conditions the infiltrating rainfall usually creates a perched water table, which leads to the development of positive pore water pressures at the interface between layers of contrasting permeability. Other modes of positive pore pressure development are artesian exfiltration from bedrock or rapid flashing (e.g., Reid et al., 1997). The rapid build-up of positive water pressures can be detected by pressure sensors installed inside open standpipe piezometers or directly buried into the ground to get faster response in low permeability soils (LaHusen, 2005; Berti and Simoni, 2010; Comiti et al., 2014). Most commercially available sensors provide measurements of pressure head with an accuracy of few millimetres and are compensated to accommodate temperature induced variation. Similarly, an initiating failure can also occur under partially saturated conditions due to a decrease of soil matric suction during rainfall (Crosta and Dal Negro, 2003; Godt et al., 2009). Matric suction controls both the permeability and the shear strength of soils and directly affects slope stability. Standard tensiometers can measure soil suction up to $100 \mathrm{kPa}$ and require no site-specific calibration. However, they need regular maintenance to keep the chamber behind the porous tip filled with water (although modifications can be made to extend the period of time between 
visits, e.g., Smith and Kean, 2018). This is a severe limitation as most debris-flow source areas are difficult to access. Alternatively, soil suction can be measured using porous ceramic disc tensiometers (Hürlimann et al., 2014) or estimated through indirect methods such as time-domain reflectometry, frequency-domain reflectometry or neutron probes. Indirect methods estimate soil suction from a measurement of soil water content and require knowledge of the soil water retention curve.

\subsubsection{Debris flows initiated by channel runoff}

Debris flows triggered by surface runoff are more challenging to monitor. In principle, the monitoring system should observe the process of runoff generation in the debris-flow channel and detect the critical level of surface water flow required to start bed erosion/mobilization. Such measurements, however, are difficult to obtain due to the harsh field conditions (very steep channels, high relief, rockfalls) and for these reasons only a few studies are available on that subject (Berti and Simoni, 2005; Imaizumi et al., 2005; McCoy et al., 2012; Kean et al., 2013; Gregoretti et al., 2016; Capra et al., 2018). In these studies, the authors obtained video footage of the initiation process from cameras installed in the source areas of the debris flow and detected the occurrence of subsurface stormflow into the channel bed using pressure sensors buried at shallow depth. The combination of video footage and pore pressure data allowed these researchers to identify the hydrologic behaviour of the headwater catchment and/or channel network in response to rainfall of varying duration and intensity. A critical aspect of these monitoring systems is the power/memory usage of the cameras that must be activated only during an event and for a limited time. A typical setup is a full high-definition time-lapse camera powered by an external battery and triggered by the rain gauge when the rainfall intensity exceeds a certain threshold. This threshold can be set at a low value (e.g., $0.6 \mathrm{~mm}$ in 1 minute; Gregoretti et al., 2016) to document the hydrologic response to both critical and non-critical storms. Surface-flow velocity and discharge volumes can be extracted from image analysis, although the irregular channel section and the flow turbulence commonly result in large estimation errors. To overcome these problems, Gregoretti et al. (2016) built a sharp-crested weir at the outlet of a small headwater watershed and obtained a direct measure of runoff discharge in the debris-flow source area. However, the weir required continuous maintenance to keep the stilling basin free of debris and to repair damage due to rockfalls, illustrating the difficulties in monitoring these processes.

\subsection{Sensors measuring flow dynamics}

A variety of sensors are used to measure debris-flow dynamics and most of them can be placed in one of the following classes: i) devices that measure the ground or infrasound vibrations produced by the flowing mass, ii) devices that sense the flow depth, iii) devices that measure the basal stress and sediment entrainment, iv) devices that record surface flow velocity. Comparison of data recorded by different sensors installed along the flow trajectory can provide information on the mean front velocity (Arattano and Marchi, 2005). The hydrograph and the peak discharge of the flow can be determined from a combination of flow velocity and flow cross-section, the latter of which can be approximated from the flow depth. Then, the total volume of the debris flow can be estimated by integrating the hydrograph. There are also simplified approaches to obtain the total volume of the debris flow (e.g., Hürlimann et al., 2014). The most accurate estimates of mean front velocity, peak discharge, and total volume are typically obtained using paired sensors installed within a short channel reach to reduce uncertainties resulting from abrupt changes in flow dynamics that can occur over long reaches. 


\subsubsection{Ground and infrasound vibrations}

Rapid mass movements such as debris flows generate seismic, sonic, and infrasound waves as they travel downslope along the channel (Arattano and Moia, 1999; Abancó et al., 2014; Schimmel et al., 2018). The vibrations induced by these waves (in the ground or in the air) are produced by solid particle impacts on the channel bed and by flow turbulence. Studies of debris-flow induced seismicity have received considerable attention, because they can be used to detect the occurrence of a flow, to characterise the flow type, and estimate debris-flow velocity and even sediment entrainment (LaHusen, 2005; Kean et al., 2015; Bel, 2017; Lai et al., 2018). The ground vibration can be recorded by different sensors including seismometers, geophones, or accelerometers (e.g., Itakura et al. 2000). Vertical geophones are the most frequently used devices for debris-flow detection, because they are inexpensive and easy to install compared to seismometers. Their output is a voltage proportional to the ground vibration velocity in a specific working frequency range.

Seismic techniques are attractive, as ground vibration detectors can provide continuous information in time about a broad spectrum of processes, ranging from bedload transport to debris flows. The seismic amplitude measured along an active channel is correlated to the energy of the debris flow and thus with the mass and the velocity of the different surges (Coviello et al., 2019a). This highlight the potential of indirect seismic methods for the characterization of debris flows. However, the analysis of ground vibrations induced by fluvial processes is a complex task as they depend on many factors related to both the source characteristics (debris-flow velocity, sediment concentration, grain size) and other conditions such as distance between sensor and the channel, the crossed geological materials or the assembly of the sensor (Galgaro et al., 2005; Huang et al., 2007; Cole et al., 2009; Chou et al., 2010; Abancó et al., 2014; Coviello et al., 2018; Lai et al., 2018).

The data acquisition requirements are another important consideration when recording high-frequency seismic and infrasound signals. Some sites record the raw data at a high sampling rate, while others apply a transformation and simplification of the signal to cope with functional constraints like limited power consumption, data storage, and telemetry. There are two main methods employed for the signal simplification: the transformation into amplitude and the transformation into impulses (Arattano et al., 2014). The amplitude is defined as the envelope of the raw signal, which is typically computed as the mean of the absolute value of the raw signal over a time window, for example, 1 second. The transformation into impulses is determined by setting an amplitude threshold and counting an impulse each time the amplitude threshold is exceeded.

Apart from geophones that are normally mounted along the channel bed, infrasound and seismometers have been installed at locations that are hundreds or even thousands of metres from the trajectories of debris flows. In these cases, the analysis focusses on frequencies of a few Hertz, rather than the much higher frequency used for near-torrent monitoring. In spite of signal attenuation that occurs at sensors installed at large distances, debris flows have been investigated under such conditions in many recent studies providing valuable information on the source characteristics (Burtin et al., 2016; Huang et al., 2017; Walter et al., 2017; Lai et al., 2018). The inversion of broadband seismic data can be also used to identify the sequence of events during the debris flow and to constrain the results of numerical modeling. Regarding the analysis of infrasound signals, this technique was initially used for the detection of snow avalanches, but various recording systems have successfully applied it to detect and study debris flows (Zhang et al., 2004; Schimmel et al., 2018).

\subsubsection{Flow stage}

Stage measurements, combined with cross-sectional geometry and velocity measurements, are generally used to estimate flow hydrographs. Like vibration sensors, flow-depth sensors can be used to determine the mean velocity of the flow 
front, when several sensors are distributed at different locations along the channel. Ultrasonic, radar or laser devices are the most common sensors used for stage measurements. They record the distance from a fixed point to the flow surface at a point (point laser), by a cone with variable opening angles (radar and ultrasonic device), or by a 2-dimensional profile (2D-profile laser). Two-dimensional laser profiles provide the best information about the geometry of the flow surface (Jacquemart et al., 2017; Hübl et al., 2018). Indeed, depending on the debris-flow behaviour, the transverse profile of the free surface may be highly convex, and the measurement of a single point may lead to significant uncertainties in the determination of the flow cross-sectional area. It is recommended that the stage measurement should be done at cross sections controlled by check dams or bedrock to avoid misestimating the flow depth, since debris flows may entrain sediment resulting in substantial bed scour. However, deposition of sediments at the measuring section may also occur. Comparing radar and laser devices, parallel operation investigations have shown that radar measurements record a smoothed hydrograph, whereas laser measurement more accurately resolves the irregularities of the flow surface. Laser data, however, can include measurements of splatter during a highly turbulent flow, which may not be representative of the actual flow surface. In contrast, smoothed radar measurements may miss the peak flow stage and therefore the peak discharge may be underestimated. Regarding the temporal cross correlation for velocity calculations, it is important to note that the radar measurement usually records the peak a few seconds later than the data recorded by a laser (Jacquemart et al., 2017).

\subsubsection{Pore fluid pressure and basal, lateral, and impact stress}

Sensors can be installed in the channel bed to measure normal or shear force and pore-fluid pressure at the base of a debris flow. Pore-fluid pressure sensors easily detect the passing debris flows, because excess pore pressures exceeding the equilibrium hydrostatic pressures, are recorded. Pressure transducers have long been used in debris-flow research (e.g., Berti et al., 1999) and play a role in the monitoring at many catchments. Pore-fluid pressure is sometimes related to the measurements of normal or shear forces using force plates and load cells (McArdell et al., 2007; McCoy et al., 2010; Nagl and Hübl, 2017). At a few monitoring sites, a sophisticated "sensor wall" or "sensor pillar" is installed, where velocity profiles, shear forces and impact forces are recorded at different depths inside a debris flow. At the Illgraben site in Switzerland, a vertical shear wall was constructed parallel to the flow direction at a lateral channel bank (Berger et al., 2011; Wendeler et al., 2018). This instrumented wall was designed to provide information on the flow properties as a function of the height above the channel bed and consists of an array of vertical force plates, temperature probes, geophones, a laser distance device, and a video camera. At Gadria in Italy, a concrete pillar was recently constructed in the middle of the debris-flow channel. The pillar includes load cells, strain gauges, and pressure sensors (Nagl and Hübl, 2017). In fact, the impact pressure of debris flows on obstacles provides important information for both the design of active protection elements and land-use planning. However, in situmeasurements that refer to the impact of debris flows are scarce, because sensor set-up is expensive and requires substantial maintenance. Typically, load cells or deformation sensors are installed at the protection structure, which can be rigid or flexible (Wendeler et al., 2007; Hübl et al., 2009; Hu et al., 2011; Nagl and Hübl, 2017).

\subsubsection{Surface velocity}

Doppler radar techniques can be employed to measure the surface velocity of rapid mass movements. They have been successfully applied for snow avalanches and were recently implemented in debris-flow monitoring systems in China and Austria (Cui et al., 2018; Hübl et al., 2018). Doppler radar can measure velocity even during difficult weather conditions 
and it can detect moving objects in a channel reach between 15 and $250 \mathrm{~m}$ long (Hübl et al., 2018). In addition, largescale particle image velocimetry (LSPIV) has been applied to determine the surface velocity of debris flows (Chang and Lin, 2007; Kean et al., 2015; Theule et al., 2018). LSPIV needs good illumination during the debris-flow event and a video camera with standard image resolution. Most monitoring sites include one or more video cameras, which normally work when daylight is available, but some of them also have infrared lenses or high-intensity LED flood lights for video capture during night. Apart from the application of LSPIV, visual information is normally used for general characterisation of the flow process.

\subsubsection{Other sensors}

Entrainment sensors have been installed at some sites to investigate entrainment rate and timing of basal erosion (Berger et al., 2010; McCoy et al., 2012). This information is crucial for modelling debris-flow propagation and predicting the total volume, since a large part of the final debris-flow volume can be supplied by channel scouring (Theule et al., 2012). Artificial boulders or devices that can be fixed in a block have been designed to register the internal dynamics of debris flows such as acceleration and pressure, while they were entrained and transported by the flow (Lee et al., 2010; Apostolov and Benoît, 2017). Passive integrated transponders have been used to measure travel distances of cobbles during debris flows (McCoy et al. 2011).

\subsection{Data acquisition, data transmission, and power supply}

In contrast to other landslides, debris flows are impulsive phenomena. Therefore, most monitoring systems differentiate between a "non-event mode" with a low frequency recording (one sample within several minutes) and an "event mode" with a high sampling rate (1 to 1000 samples per second). This differentiation between the two modes is especially important for accurate data recording of the flow dynamics during the "event mode". On the other hand, meteorological sensors generally have a constant sampling rate. Collection of high-frequency data during debris-flow events requires a robust switching system to shift from "non-event mode" to "event mode". Two main approaches exist to switch between modes. One approach requires the flow to interact with a physical switch such as a trip wire or pendulum located in the channel. The other approach uses a threshold related to rainfall or ground vibration to switch to "event mode".

The power supply and data transmission are two other important components of debris-flow monitoring systems. Debrisflow catchments are typically located in remote and harsh areas with limited duration of direct sunlight and limited coverage of mobile communications. Data transmission is normally performed by cellular modem or radio and less commonly with satellite telemetry or a wired connection. A network connection to the monitoring system is not only used for data transmission, but also for remote monitoring of system state-of-health data. Since modems are often characterised by large power consumption, data transmission is generally performed during a specific time interval, otherwise leaving the modem turned off or in quiescent mode. Regarding the power supply, some sites use low-power wireless sensors networks (e.g., Cho et al., 2008), which operate using small batteries and without large solar panels. Other sites, which include devices that need more power consumption, are supplied by alternative energy sources such as water or wind power, AC power line, or fuel cells (Chambers et al., 2013; Magno et al., 2014). 


\section{Examples}

\subsection{Overview}

We present nine monitoring sites in this section. Five are located in Europe (four in the Alps and one in the Pyrenees), one is in the USA, and three are in Asia. An overview image of each catchment is given in Figure 1, and the exact location of the nine sites can be found in the kmz file (see supplementary material). Except Kamikamihori (Japan), which was established in 1970, all the other sites started monitoring during the last two decades (Table 2). Debris-flow mitigation structures, such as check dams, are present in all of the catchments, except Chalk Cliffs (USA), Ergou (China) and Rebaixader (Spain).

The principal characteristics of the nine selected catchments, as well as the sensors installed at each site are listed in Tables 2 and 3Table 3. A detailed description of each monitoring site is given in the following sections using an alphabetic order of the primary drainage channel. Most catchments cover a drainage area of less than $\sim 10 \mathrm{~km}^{2}$ and the corresponding channel length is less than $\sim 5 \mathrm{~km}$. Only the Ergou (mainland China) and Shenmu (Taiwan) sites drain larger areas and have longer channels (see Table 2). Information on the most active sub basin of these two sites is also included in Table 2. Fan slope and Melton ratio are two morphometric parameters that are commonly used to describe catchments debrisflow activity (e.g., Bardou, 2002; Wilford et al., 2004; Bertrand et al., 2013). We analyse these two parameters in Section 4.

Table 3 summarises the sensors installed at each of the nine monitoring sites. To characterise initiation conditions, one or more rain gauges are installed at each site, and soil moisture or pore water pressure sensors are available at four sites. Different devices are used to measure flow dynamics at the sites - the most common of these record flow stage (included at all nine monitoring systems) and seismic or infrasonic devices (only Ergou does not have such sensors). Video (or photo) cameras are also used at all nine monitoring systems. The surface velocity of the debris flows is measured by Doppler radar at three sites. Force plates with connected load cells are installed at five sites and more specific devices like the erosion sensors have been installed temporally in two debris-flow torrents.

Table 2: General characteristics of the nine monitoring sites selected in this review. Values of most active sub-basin are added in brackets for Ergou and Shenmu.

\begin{tabular}{|l|l|l|l|l|l|l|l|l|l|l|}
\hline Catchment & code & $\begin{array}{l}\text { Country - } \\
\text { Region }\end{array}$ & $\begin{array}{l}\text { year } \\
\text { of } \\
\text { installation }\end{array}$ & $\begin{array}{l}\text { \# of } \\
\text { check } \\
\text { dams }\end{array}$ & $\begin{array}{l}\text { retention } \\
\text { basin }\end{array}$ & $\begin{array}{l}\text { maximum } \\
\text { altitude } \\
(\mathrm{m} \text { asl })\end{array}$ & $\begin{array}{l}\text { drainage } \\
\text { area } \\
\left(\mathrm{km}^{2}\right)\end{array}$ & $\begin{array}{l}\text { channel } \\
\text { length } \\
(\mathrm{km})\end{array}$ & $\begin{array}{l}\text { mean slope } \\
\text { of fan } \\
(\mathrm{degree})\end{array}$ & $\begin{array}{l}\text { Melton } \\
\text { index }\end{array}$ \\
\hline Chalk Cliffs & $\mathrm{CC}$ & USA & 2004 & 0 & no & 3140 & 0.3 & 1 & 9 & 1.07 \\
\hline $\begin{array}{l}\text { Ergou } \\
\text { (WII basin) }\end{array}$ & $\begin{array}{l}\text { Er } \\
\text { Er-WII }\end{array}$ & $\begin{array}{l}\text { mainland } \\
\text { China }\end{array}$ & 2013 & 0 & yes & $\begin{array}{l}4120 \\
(3090)\end{array}$ & $\begin{array}{l}39.4 \\
(2.4)\end{array}$ & $\begin{array}{l}11.5 \\
(1.6)\end{array}$ & $\begin{array}{l}4 \\
(9)\end{array}$ & $\begin{array}{l}0.49 \\
(1.26)\end{array}$ \\
\hline Gadria & Ga & Italy & 2011 & 20 & yes & 2945 & 6.3 & 3 & 7 & 0.62 \\
\hline Illgraben & Il & Switzerland & 2000 & 30 & no & 2716 & 11.7 & 5.5 & 10 & 0.62 \\
\hline Kamikamihori & Ka & Japan & 1970 & 8 & no & 2455 & 0.8 & 2.5 & 3.5 & 1.08 \\
\hline Lattenbach & La & Austria & 2002 & 33 & no & 2930 & 5.3 & 5.2 & 8 & 0.91 \\
\hline Réal & Réa & France & 2010 & 8 & no & 2090 & 2.3 & 2.6 & 9 & 0.57 \\
\hline Rebaixader & Reb & Spain & 2009 & 0 & no & 2475 & 0.53 & 1.4 & 18 & 1.55 \\
\hline $\begin{array}{l}\text { Shenmu } \\
\text { (Aiyuzi basin) }\end{array}$ & $\begin{array}{l}\text { Sh } \\
\text { (Sh-A) }\end{array}$ & Taiwan & 2002 & 3 & no & $\begin{array}{l}2850 \\
(2500)\end{array}$ & $\begin{array}{l}72.2 \\
(4.05)\end{array}$ & $\begin{array}{l}17.7 \\
(3.3)\end{array}$ & $\begin{array}{l}8.5^{2} \\
\left(8.5^{2}\right)\end{array}$ & $\begin{array}{l}0.20 \\
(0.61)\end{array}$ \\
\hline
\end{tabular}

${ }^{1}$ channel length of primary channel

2 downstream channel bed slope, because no fan is available 
Table 3: Sensors installed at the nine selected monitoring sites. Values in brackets refer to sensors incorporated in complementary warning/detection systems. PWP stands for pore water pressure and SM for soil moisture.

\begin{tabular}{|c|c|c|c|c|c|c|c|c|c|c|c|c|c|c|c|c|}
\hline \multirow[t]{2}{*}{ Catchment } & \multirow[t]{2}{*}{$\begin{array}{l}\text { rain } \\
\text { gauge }\end{array}$} & \multirow[t]{2}{*}{$\begin{array}{c}\text { video } \\
\text { camera }\end{array}$} & \multicolumn{4}{|c|}{ flow depth sensors } & \multicolumn{3}{|c|}{$\begin{array}{l}\text { seismic or infrasonic } \\
\text { sensors }\end{array}$} & \multirow{2}{*}{$\begin{array}{c}\text { surface } \\
\text { velocity } \\
\text { sensor }\end{array}$} & \begin{tabular}{|l|} 
erosion \\
sensor $^{1}$
\end{tabular} & $\begin{array}{l}\text { PWP } \\
\text { sensor }\end{array}$ & $\begin{array}{l}\text { force } \\
\text { plate }\end{array}$ & \multirow{2}{*}{$\begin{array}{l}\text { Sensor } \\
\text { pillar/ } \\
\text { wall }^{2}\end{array}$} & \multirow{2}{*}{$\begin{array}{c}\text { SM / } \\
\text { PWP } \\
\text { sensor } \\
\text { installed } \\
\text { in } \\
\text { source } \\
\text { area } \\
\end{array}$} & \multirow{2}{*}{\begin{tabular}{|c} 
trip \\
wire \\
sensor
\end{tabular}} \\
\hline & & & $\begin{array}{l}\text { ultra- } \\
\text { sonic }\end{array}$ & radar & $\begin{array}{l}\text { laser } \\
\text { (point) }\end{array}$ & $\begin{array}{c}\text { laser } \\
2 \mathrm{D} \\
\text { scanner }\end{array}$ & geophone & $\begin{array}{l}\text { seismo- } \\
\text { meter }\end{array}$ & $\begin{array}{l}\text { infra- } \\
\text { sound }\end{array}$ & & \multicolumn{3}{|c|}{ buried in channel bed } & & & \\
\hline Chalk Cliffs & 6 & 6 & & & 3 & & 2 & & & & 1 & & 1 & & $6^{1}$ & \\
\hline Ergou & 3 & 3 & 3 & & & & & & & 3 & & 2 & 1 & & $2 / 0$ & \\
\hline Gadria & 3 & 4 & & 3 & & 1 & $4(3+2)$ & & (2) & 1 & & & 2 & 1 & & \\
\hline Illgraben & 3 & 4 & 1 & $2(2)$ & 2 & & $5(3)$ & $8^{1}$ & $1^{1}$ & & 1 & 1 & 1 & 1 & $1 / 0$ & \\
\hline Kamikamihori & 1 & 3 & 2 & & & & & 1 & & 1 & & 2 & 1 & & $3^{1 / 0}$ & 30 \\
\hline Lattenbach & 1 & 1 & & 4 & & 1 & 2 & 1 & 3 & 1 & & & & & & 4 \\
\hline Réal & 2 & $2^{3}$ & 2 & 1 & & & 8 & & & & & & & & & \\
\hline Rebaixader & 1 & 1 & 1 & 1 & & & 5 & & & & & & & & $8 / 2$ & \\
\hline Shenmu & 2 & 4 & & 1 & & & 2 & 4 & & & & & & & $2 / 0$ & 6 \\
\hline
\end{tabular}

temporary installation

${ }^{2}$ sophisticated set up with multiple sensors: Gadria (14 load cells, 8 strain gauges, 9 earth pressure sensors, 1 3D-accelerometer 1 ultrasonic device and 2 displacement sensors ) and Illgraben (6 load cells, 18 geophones, 8 temperature probes, 1 laser device and 1 video camera)

${ }^{3}$ photo camera 

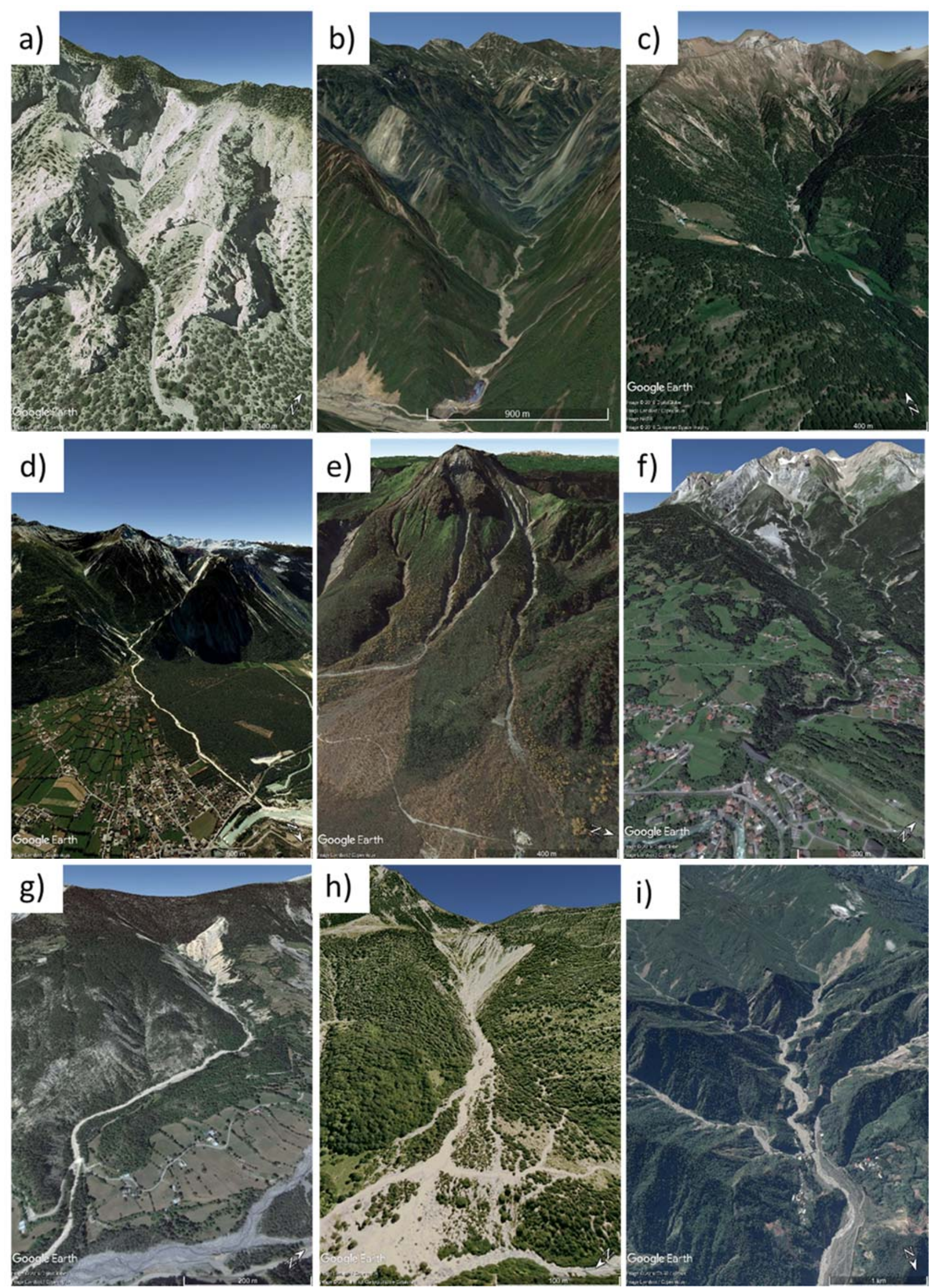

Figure 1: Debris-flow monitoring sites described herein. a) Chalk Cliffs (USA), b) Ergou (mainland China), c) Gadria (Italy), d) Illgraben (Switzerland), e) Kamikamihori (Japan), f) Lattenbach (Austria), g) Réal (France), h) Rebaixader (Spain), i) Shenmu (Taiwan). Source: Google Earth; a kmz-file with the locations of the monitoring sites is included as supplementary material. 


\subsection{Description of monitoring sites}

\subsubsection{Chalk Cliffs, USA}

The Chalk Cliffs are located at the base of Mt. Princeton in the Sawatch Range of the Rocky Mountains, in central Colorado. The U.S. Geological Survey established a monitoring network in the upper reach of the catchment $\left(0.06 \mathrm{~km}^{2}\right)$ in May 2004 (Coe et al., 2008). Since then, this network has undergone many changes as research goals and technology have evolved and equipment has been lost to debris flows. Currently, there are multiple stations in the watershed and on the fan for the study of varied mass-movement phenomena. Since its inception, the instrumentation has been used to study debris-flow initiation conditions and mechanisms, flow dynamics, sediment entrainment, bedrock erosion, and rockfall sedimentation..

The Chalk Cliffs are composed of highly fractured and hydrothermally altered quartz monzonite - a result of faulting and hydrothermal activity due to active fault breaching of the adjacent Sawatch Range normal fault (Miller, 1999). The name Chalk Cliffs is taken from the white colour of the laumontite and leonhardite alteration minerals that primarily compose the formation (Miller, 1999; Coe et al., 2008, 2010). The altered material is weak and weathers rapidly to fill the channels with sediment, both through dry ravel and rockfall processes. Weathering processes have created steep bedrock slopes $\left(40^{\circ}\right.$ to vertical) and colluvium-covered slopes (about $25^{\circ}$ to $40^{\circ}$ ), with the main channel having a slope between $5^{\circ}$ and $15^{\circ}$ (Coe et al., 2008; Staley et al., 2011; McCoy et al., 2013). The North American Monsoon annual precipitation pattern reaches maturity during July and August and typically brings relatively intense convective storms. These storms create runoff-generated debris flows that entrain accumulated sediment from the channel (Coe et al., 2008). No constructed protection measures exist except a channel incised in the bajada that is routinely excavated to create a predictable path for flows to cross County Road 162 and enter Chalk Creek (Figure 2).

The Chalk Cliffs monitoring network consists of a primary group of three channel-monitoring stations to record data on debris-flow dynamics and four auxiliary stations to record additional data on rainfall, rockfall, firehose processes, and river-fan interactions (Figure 2). The three primary stations are multi-sensor monitoring stations: the upper station (US), middle station (MS), and lower station (LS). The other stations measure rainfall and record high-definition video of various debris-flow processes. The video station (VS) records a reach-scale video of debris flows as they flow beneath the Upper Station, the firehose station (FH) records video of debris flows initiated by high-energy clear water flow, and the confluence stations (CS1, CS2) record video of the Chalk Creek - debris-flow interactions. Frequent rockfall and debris-flow activity necessitates on-going equipment repair and replacement of destroyed equipment.

The US has the most sensors and is located along an upper reach of the basin with an upstream watershed area of 0.06 $\mathrm{km}^{2}$. This station features a channel-spanning aluminium truss bridge to which enclosures, a 70-watt solar power system, and sensors are attached. At the same station, two dataloggers (Campbell Scientific CR1000 and RefTek RT130s) are dedicated to debris-flow monitoring by recording data on rainfall, flow stage, basal pore-fluid pressure, basal normal force, and ground vibrations. The US is typically equipped with two rain gauges (Hydrological Services TB4), a laser for stage measurements (Sick DT50Hi), a $232 \mathrm{~cm}^{2}$ force plate (with Tovey Engineering SWS10-10k), a DSLR based video camera, a wind sensor (MetOne 34b), an air temperature and humidity sensor (CS216), two rock temperature profiling sensors, and upstream and downstream triaxial geophones (SolGeo/Geospace 4.5 Hz). A Global System for Mobile communication (GSM) modem is used to transmit low frequency (1 minute) rainfall, flow depth, and system state-ofhealth information. Former temporary installations have included multiple bed-mounted pressure transducers for measuring pore-fluid pressure, erosional flow depth sensors, and multiple volumetric water content sensors (Decagon EC-5). The US is collocated with a temporary station to monitor rockfall, which is the main source of debris-flow material. The MS and LS are scaled-down versions of the US (primarily measuring rainfall and flow stage, and formerly basal 
pore-fluid pressure) and use a cantilevered rod to position the stage laser above the thalweg. The MS measures flow depth downstream of the confluence of the East and West channels, and the LS records flow depth near the outlet of the steepland watershed $\left(0.3 \mathrm{~km}^{2}\right)$ near the apex of the fan. Each station uses a rainfall threshold to trigger high frequency measurements of debris-flow stage at $10 \mathrm{~Hz}$, rainfall at $0.5 \mathrm{~Hz}$ and ground vibrations at $1000 \mathrm{~Hz}$ (only at US). Additionally, this rainfall threshold is used to trigger video cameras (primarily $1280 \times 720$, at 60 frames per second) located at US, VS, MS, FH, CS1 and CS2.

The monitored basin has generally produced one to five debris-flow events annually since 2004 (Coe et al., 2008, 2010; McCoy et al., 2012). Coe et al. $(2008,2010)$ identified an intensity-duration rainfall threshold of $I=6.61 D^{-0.77}$, where $I$ is mean intensity and $D$ is storm duration a storm is defined as an event with sustained 10 -minute intensity of $1.5 \mathrm{~mm} / \mathrm{h}$ or greater. Ten-minute rainfall intensities less than $1.5 \mathrm{~mm} / \mathrm{hr}$ generally produce negligible overland flow. Once overland flow in the channels reaches $0.15 \mathrm{~m}^{3} / \mathrm{s}$, sediment begins to be entrained into the flow (Coe et al., 2008). As entrained material coalesces into a debris flow, it is characterized by multiple surges (McCoy et al., 2010; Kean et al., 2013), with each surge generally having a coarse-grained snout transitioning into a more fluid-rich tail. Kean et al. (2013) suggested that the periodicity of the surges may be controlled by upstream variations in channel gradient, where transported sediment may temporarily accumulate in low-gradient sections of channel until downstream forces generated by gravity acting on the accumulated material remobilize the sediment into a moving surge. The characteristics of debris-flow surges also vary throughout the season and are dependent on rainfall intensity and sediment availability (Coe et al., 2008). McCoy et al. (2011) report surge front-velocities $(u)$, of flows measured at US, as a function of flow depth $(h)$ where $u=3.6 h^{1 / 2}$. Using this flow depth-velocity relationship, they integrated the stage time series to determine event volumes at the US watershed $\left(0.06 \mathrm{~km}^{2}\right)$ for four debris flows and found total debris-flow volumes ranging from 35 to $822 \mathrm{~m}^{3}$ per event. Debris flows at the lower end of this volume range are depositional in nature and do not have the necessary energy to transport material $0.6 \mathrm{~km}$ to the confluence with Chalk Creek, and typically stall within low gradient areas of the channel. In contrast, debris flows at the larger end of this volume range tend to incorporate material and gain velocity as they propagate downstream. McCoy et al. (2012) measured flow and erosion statistics for six erosional debris-flow events at the US and found that, regardless of water content, entrainment occurred progressively from the bedload surface to bedrock, and en masse bedload failure was not observed to contribute to entrainment. 


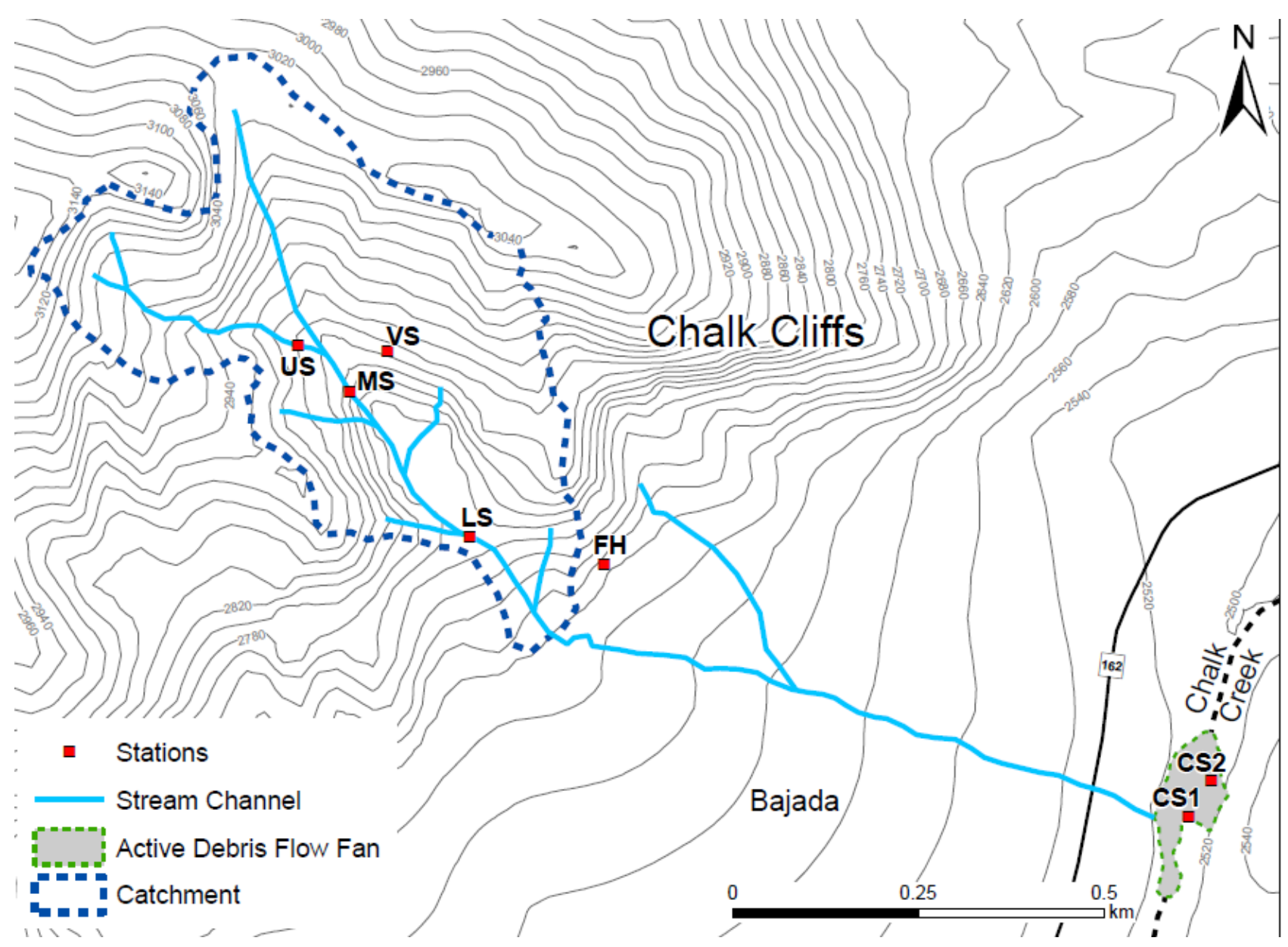

Figure 2: The Chalk Cliffs (USA) monitoring site. Topographic map and location of the three primary monitoring stations: Upper- (US), Middle- (MS) and Lower- (LS) Stations. Auxiliary video cameras are installed at station VS, the firehose station $(\mathrm{FH})$ and the confluence stations (CS1, CS2). 


\subsubsection{Ergou, mainland China}

In early 2013, the Institute of Mountain Hazards and Environment (IMHE, Chinese Academy of Sciences) selected the Ergou catchment as a monitoring site because of its frequent debris flows. The frequency was especially high (2 to 3 events per year) following the 2008 Wenchuan Earthquake, which occurred about $6 \mathrm{~km}$ SSW of the catchment (Guo et al., 2016a). The objectives of this monitoring project are: i) investigate the spatial variation of rainfall and identify the thresholds for debris flows, ii) record the hydrographs and flow properties of different basin scales, and iii) investigate the annual variation of debris-flow activity. These monitoring goals were defined according to specific conditions of this area - water runoff that transport the solid material in the channel is the main mechanism of debris-flows initiation, and debris-flow frequency and magnitude will likely change with time due to decreasing availability of loose solid materials. The catchment is a tributary of Minjiang River, covers an area of $39.4 \mathrm{~km}^{2}$ and has a channel length of $11.5 \mathrm{~km}$. The maximum elevation is $4120 \mathrm{~m}$ asl, decreasing to $990 \mathrm{~m}$ asl at the outlet. The average slope in the headwater region is $40^{\circ}$. In most of the channel sections, the gradient is between $6^{\circ}$ and $8^{\circ}$, with several localized drops along the channel. From a geological point of view, the watershed is located between the Back and Central Faults, two of the three main seismogenic faults of the Longmenshan Fault (Guo et al., 2016a; Cui et al., 2018). Bedrock in the debris-flow initiation area primarily consists of Archean metamorphic rocks, with some early Proterozoic gabbro and Permian sedimentary rocks. The topography is typical of landscapes formed by tectonic uplift and subsequent fluvial erosion. The Ergou area has a continental monsoon climate, and the rainfall season is between April and September. The annual average precipitation at the station near the outlet (R3) is $1200 \mathrm{~mm}$.

The monitoring system includes three stations (S1, S2 and S3; Figure 3) that principally focus on the measurements of flow dynamics (flow depth, flow velocity). In addition, three tipping-bucket rain gauges with a resolution of $0.5 \mathrm{~mm}$ record the precipitation at R1, R2 and R3 (Figure 3). The flow velocity and flow depth are measured with a scan rate of 1 minute at S1, S2 and S3 by both flow radar speed indicators (HR-20A, Shenzhen Huaru Technology Co. Ltd.) and ultrasonic stage meters (TSS908, Beijing Guda instrument Co. Ltd.). In addition, a 1 x $1 \mathrm{~m}^{2}$ force plate with four cornermounted vertical load cells (MD-MT, MEOKONG) was installed at S1. These devices provide information on the flow discharge (product of the cross-sectional flow area and the mean velocity), and the flow density (using normal stress and flow depth measurements). Finally, three video cameras were installed to validate the measured data at each monitoring station. The stations are powered by batteries $(100 \mathrm{Ah})$ and solar panels $(150 \mathrm{~W})$. All the data (except video) are transmitted automatically to the IMHE server in Chengdu every 10 minutes, via GPRS (General Packet Radio Service) and BDS (BeiDou Navigation Satellite System) approaches. The videos are stored in an on site hard disk, which is replaced in situ each month.

Eight debris-flow events were successfully recorded during the time period from 2006 to 2008, and this time period corresponded to year 6 to 8 after the Wenchuan earthquake. The observed debris flows were turbulent mixtures of water and sediment that also included large boulders. They differed from hyperconcentrated flows, as large boulders were observed in the flows. The densities of the debris flows are no more than $1.85 \mathrm{~g} / \mathrm{cm}^{3}$. The peak debris-flow discharge was $21 \mathrm{~m}^{3} / \mathrm{s}$ at the monitoring station S2 corresponding to the sub-basin WII with an area of $2.4 \mathrm{~km}^{2}$ and $187 \mathrm{~m}^{3} / \mathrm{s}$ at station S3 (draining the entire catchment). These peak discharges were 7 to 15 times larger than the normal basal runoff. The maximum recorded flow velocities were $7.1 \mathrm{~m} / \mathrm{s}$ in the tributary (S2) and $5.1 \mathrm{~m} / \mathrm{s}$ and the main channel (S3). The debrisflow volume, $V$, was integrated from the discharge hydrographs and an empirical relationship between peak discharge, $Q_{\max }$, and $V$ was determined based on 15 surges recorded at S2: $Q_{\max }=0.26 V^{0.39}$ (Cui et al., 2018).

The comparison of the rainfall data measured at the three gauges (R1, R2 and R3) showed that precipitation in the upper parts of the catchment (R1 and R2) is remarkably higher than the values measured at the outlet (R3). For example, the 
total rainfall measured during the rainy season (May to September) in the period of 2014 to $2016 \mathrm{was} 1083 \mathrm{~mm}$ at R3, but almost double $(2028 \mathrm{~mm})$ that at R1. Finally, a rainfall threshold was defined using the mean rainfall intensity, $I$, and total duration, $D$, measured at gauges R1 and R2. The threshold can be expressed by $I=65.78 D^{-0.83}$ and is much higher than the other thresholds proposed in the same region for the period between 2008 and 2013, shortly after the earthquake $\left(I=14.71 D^{-0.79}\right.$; Guo et al., 2016b).

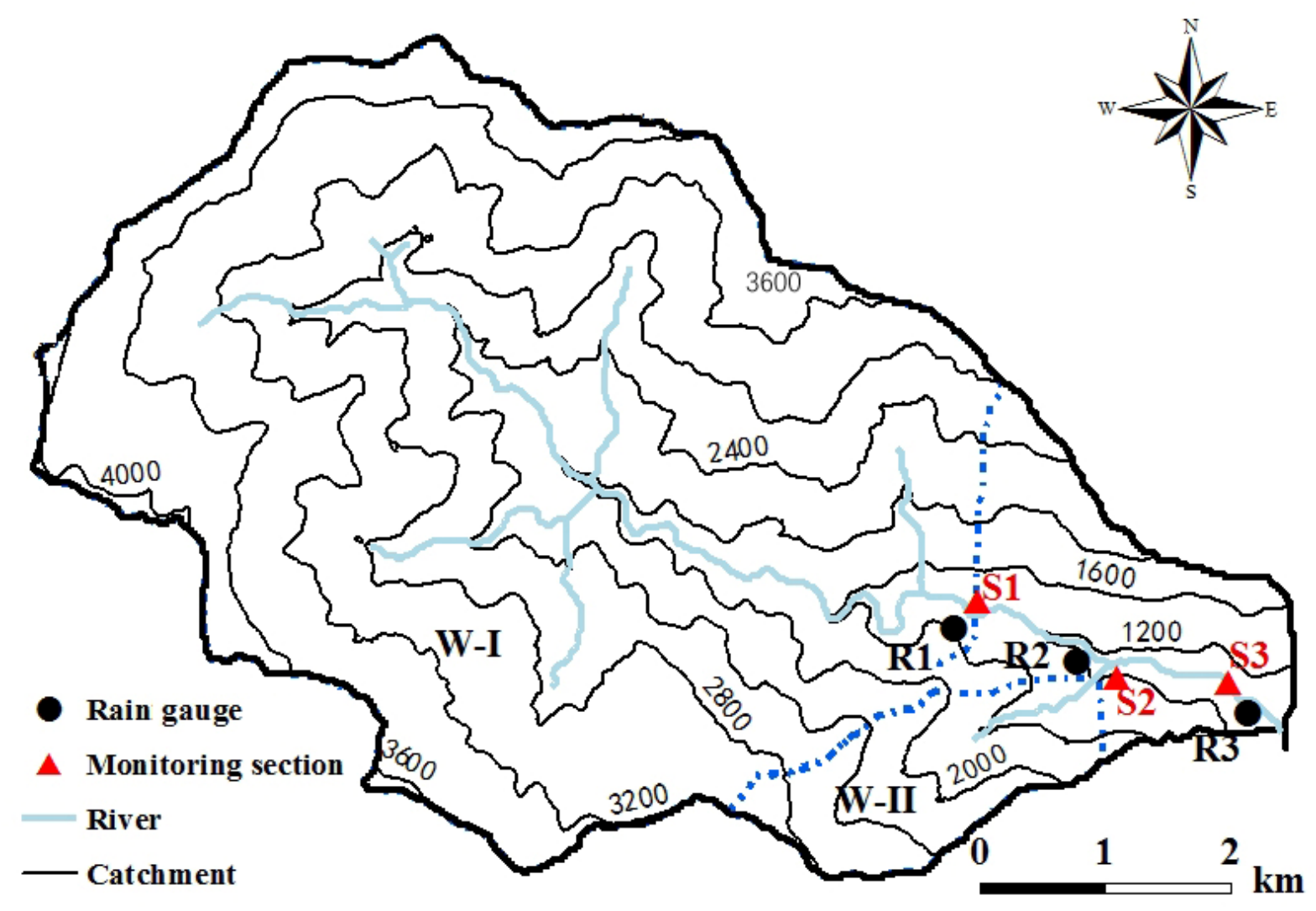

Figure 3: The Ergou (mainland China) monitoring site. Topographic map and location of the monitoring stations (S1, S2 and S3: monitoring stations; R1, R2 and R3: rain gauges). The limits of sub basin W-I and W-II are shown by dotted blue lines (adapted from Cui et al., 2018).

\subsubsection{Gadria, Italy}

The Gadria basin is located in the Venosta Valley, northeastern Italian Alps, and situated in the Adige River basin. The Autonomous Province of Bozen-Bolzano established the first, permanent monitoring network at Gadria in spring 2011 (Comiti et al., 2014). Since then, the network has undergone many changes as research goals have evolved and a number of temporary monitoring installations have taken place, especially in the upper basin. As of 2019, there are two main areas equipped for debris-flow monitoring at Gadria. The lower station is located at the fan apex of the alluvial fan at an elevation ranging from 1400 to $1450 \mathrm{~m}$ asl (Figure 4). The objectives of monitoring at this station are to characterise flow dynamics and erosion/deposition processes and to develop warning procedures. The upper station is located at an elevation of about $2200 \mathrm{~m}$ asl. and is designed to investigate initiation conditions and triggering processes. 
The Gadria basin has a drainage area of $6.3 \mathrm{~km}^{2}$ and ranges in elevation from 1394 to $2945 \mathrm{~m}$ asl (Figure 4). Most of the upper portion of Gadria is underlain by paragneiss of the Mazia unit. This lithology contains frequent pegmatitic intrusions with adjacent phyllonitic transitions, the result of Permian low-grade metamorphism (Habler et al., 2009). Colluvial processes dominate the intermediate section of the basin. The sediment produced from altered and weathered material fills the channel networks through a number of mechanisms including shallow debris slides, rockfalls, and dry ravelling on the steep slopes. The Gadria basin is characterized by a dry inner-Alpine climate, with mean annual precipitation of $480 \mathrm{~mm}$ in the valley floor. The presence of steep channels, highly fractured metamorphic rocks and thick glacio-fluvial deposits, promotes chronic debris-flow activity within the basin (Comiti et al., 2014). A retention basin was constructed in 1970 to protect human settlements located on the Gadria fan, which is larger than the basin itself. This basin is periodically emptied, but some residual risk still exists as extremely large debris-flow events could exceed its capacity (Coviello et al., 2019b).

The Gadria monitoring network is composed of rain gauges (Lambrecht 1518 and Campbell Arg100), flow stage sensors (Vegapulse 68), ground vibration detectors (PASI SIS-901-050 and Geospace GS-20DX), video cameras (Mobotix M12), and soil moisture probes (Spectrum SM100). The installation of most of this monitoring equipment was supported by the Autonomous Province of Bozen-Bolzano, but some instruments were acquired and maintained by the Free University of Bozen-Bolzano, the Research Institute for Geo-Hydrological Protection (CNR IRPI) and the Institute of Mountain Risk Engineering (BOKU, Austria). The lower monitoring station is located at an elevation ranging from 1400 and $1450 \mathrm{~m}$ asl, immediately upstream of the retention basin. This station is composed of three video cameras, four vertical geophones $(10 \mathrm{~Hz})$ placed along the left channel bank, two in the ground and two on the structure of check dams (Coviello et al., 2015), and two stage sensors (Figure 4). A stable power supply and internet connection are provided by the Autonomous Province of Bozen-Bolzano. One rain-gauge and an additional stage sensor are located about $500 \mathrm{~m}$ upstream, at an intermediate station located at an elevation of about $1500 \mathrm{~m}$ asl. In 2013, a stand-alone recording unit was installed at the lower station and is devoted to the systematic test of debris-flow warning systems and algorithms (Arattano et al., 2015). The system is composed of three $10 \mathrm{~Hz}$ vertical geophones installed along the left bank of the channel and a red flashing light is activated if debris flows are noted by the detection algorithm. To further develop the research on early warning systems, two infrasound sensors and two additional geophones are installed approximately at the same location (Schimmel et al., 2018). In 2017, an instrumented pillar was built inside the main channel just upstream of the retention basin to measure vertical velocity profiles, basal normal stress, impact forces and pore fluid pressure (Nagl et al., 2018). At the upper stations, a number of instruments have been installed including two rain gauges, rain-triggered video cameras, pressure transducers (Keller DCX-22 VG, OTR OG-200/R) and soil moisture probes (Spectrum SM100, Campbell TDR). The rain gauges are continuously operating throughout the year; the other sensors, which are located inside or very close to the steep channels of the source area, are installed only during the debris-flow season to minimise the potential of destruction. In 2018, a new geophone network (DATA-CUBE with PASI geophones, Raspberry Shake 4D) was installed on one ridge separating two active channels of the upper basin to detect incipient sediment motion.

Analysis of rainfall data measured at the upper stations revealed that a maximum 10-minute rainfall can be used to distinguish triggering from non-triggering rainfall (Comiti et al., 2014). In most cases, hourly rainfall totals exceeding about $10 \mathrm{~mm}$ are likely to initiate debris flows. However, in recent years, significantly lower values of rainfall have been observed to trigger debris flows. A rainfall intensity-duration threshold was defined using data from debris-flow events that occurred between 2011 and 2018, and the lower threshold is given by the expression $I=8 D^{-0.96}$ (Marchi et al., 2019). Large-scale particle image velocimetry, LSPIV, was applied to assess the surface velocity of debris-flow surges at the lower station (Theule et al., 2018). Results show that LSPIV velocities are consistent with surge velocities calculated 
from cross correlation of nearby hydrographs. Three major debris-flow events that occurred at Gadria between 2013 and 2015 have been analysed in detail using the hydrographs, geophone signals and video footage recorded at the inlet of the sediment trap. Volume estimates of these debris flows range between 8100 and $10400 \mathrm{~m}^{3}$ and a sediment yield of about $1900 \mathrm{~m}^{3} \mathrm{~km}^{-2} \mathrm{y}^{-1}$ was calculated based on the analysis of digital elevation models obtained in the time period between 2014 and 2015 (Coviello et al., 2019b).

The warning algorithm being tested at Gadria automatically processes the amplitude information gathered from a linear array of geophones installed along the main channel (Coviello et al., 2019a). Complementary data (rainfall, flow stage measurements, video recordings) assure event characterization and alarm validation.

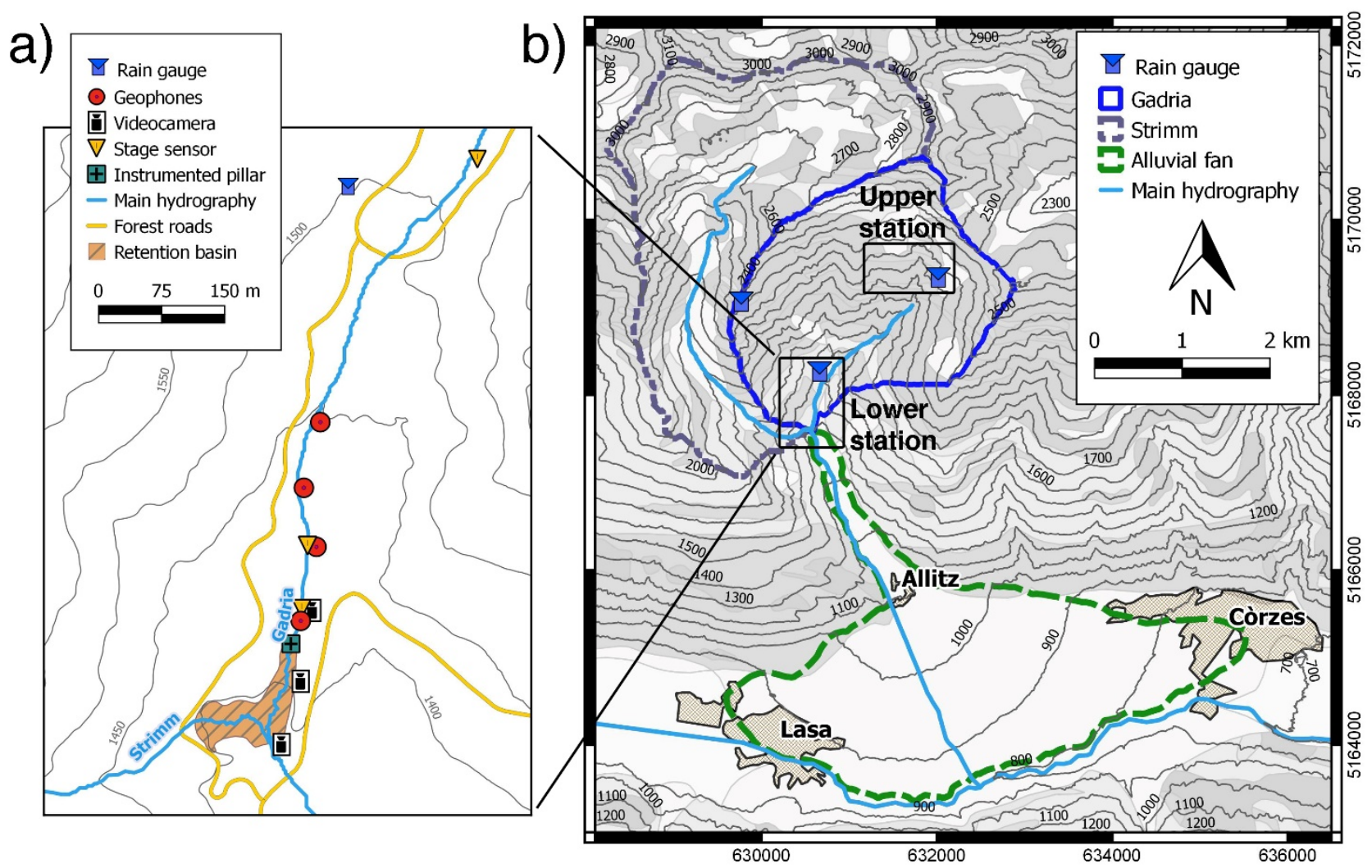

Figure 4: The Gadria (Italy) monitoring site. a) Topographic map and location of the two principal monitoring stations. b) Detailed map of the sensors installed at the lower station. UTM zone $32 \mathrm{~N}$ is used.

\subsubsection{Illgraben, Switzerland}

The Illgraben monitoring system is the main debris-flow research field site of the Swiss Federal Research Institute WSL. The monitoring system, which is located near the village of Susten, Canton Valais, was established in 2000. A multi-level warning system was installed in parallel to the research station in 2007 (Badoux et al., 2009). This system provides alarms to evacuate people from the active channel and to alert the local security commission. Sensors within the catchment automatically detect debris flows and issue alarms at three points along the channel, as well as send a text message to local hazard managers. Depending on the type of event (debris flow, debris flood, flood), the time between detection in the catchment and the arrival of debris flows at populated areas on the fan is only a few minutes (Badoux et al., 2009). The Illgraben catchment in the Swiss Alps ranges in elevation from $2716 \mathrm{~m}$ asl at the summit of the Illhorn peak to 605 $\mathrm{m}$ asl at its confluence with the Rhone River. The total drainage area covers $11.69 \mathrm{~km}^{2}$, but debris flows are initiated in 
the $4.83 \mathrm{~km}^{2}$ large western sub basin (called "active catchment" in Figure 5). The fan apex is located at $860 \mathrm{~m}$ asl and the debris fan covers an area of $7.75 \mathrm{~km}^{2}$ with a mean slope angle of $10.2^{\circ}$. The bedrock is part of the northern limb of the Penninnic nappe stack that consists of a Paleozoic crystalline core and a metasedimentary cover of Triassic quartzites, schists and limestones (Schlunegger et al., 2009). The slopes in the active catchment area (see Figure 5) are characterised by landslides and rockfalls as well as accumulation of sediment deposits in the steep gullies. The annual precipitation in the area ranges from $600 \mathrm{~mm}$ in the main valley to $900-1200 \mathrm{~mm}$ on the highest peaks of the catchment (Spreafico and Weingartner, 2005).

Debris-flow initiation is either by direct entrainment of sediment deposits due to runoff or by small landslides. Debris flows generally grow in volume by entraining sediment from the bed of the torrent channels. Debris flows occur typically following heavy rainfall produced by thunderstorms or weather fronts coming from the southwest. On average three to five debris flows, and additional debris floods, are observed every year from May to October (Badoux et al., 2009).

The monitoring system consists of four operational monitoring stations on the lower part of the fan. In addition, two detection stations and three rainfall stations are installed in the active catchment for the municipal warning system (Figure 5). The instrumentation of the four fan stations includes an overall sensor number of five geophones (Geospace $20 \mathrm{DX}$ ), each of them mounted on a concrete check dam, one ultrasonic stage sensor (Vegason 72-I/73-I), two radar stage sensors (VEGAPULS 54, VEGAPLUS SR 68), two laser stage sensors (ABB / K-Tek Solids Level LM80 Laser level transmitter and K-Tek ShureShot XP), and four video cameras (Mobotix M25M, Mobotix MX-M24M, Panasonic Colour CCTV Cameras WV-CP410 stored on Panasonic WJ-HD200 digital recorder). The additional detection stations for the municipal warning system includes another three geophones (Geospace 20 DX) and two radar stage sensors (VEGAPLUS SR 68). Data from the monitoring system are stored locally on dataloggers (Campbell Scientific, Inc. CR1000, CR800, CR200, CR10X) and are regularly transferred by GSM to a server at WSL. The entire system switches from the "non-event mode" (low frequency recording, typically 10 minutes intervals) to the "event mode" (high frequency recording, typically $1 \mathrm{~Hz}$ ) by a ground-vibration threshold reached at any individual station (Abancó et al., 2012).

The most sophisticated instrumentation is located at the monitoring station at the cantonal road bridge (see location in Figure 5). There, a $2 \times 4 \mathrm{~m}^{2}$ steel plate measures vertical and horizontal forces in the channel bed at $2 \mathrm{kHz}$ (McArdell et al., 2007; McArdell, 2016). In combination with flow depth information at this location, the density of the debris-flow mixture can be determined over time. In addition, the pore-water pressure at the base of the passing debris flows is measured by a pressure sensor. Data are stored on a PXI System (National Instruments) and reduced data are transferred by GSM Modem to a FTP directory. Just upstream of this force plate, a vertical shear wall is located on the lateral channel bank (Berger et al., 2011; Wendeler et al., 2018). This shear wall of steel reinforced concrete has a length of $14 \mathrm{~m}$ and is $2.5 \mathrm{~m}$ high. An array of six $0.3 \times 0.3 \mathrm{~m}^{2}$ force plates is mounted on the wall measuring pressure fluctuations at different flow depths with a frequency of $2 \mathrm{kHz}$. In addition, 18 geophones record the ground vibrations and 8 temperature sensors provide information on the temperatures of the flow mixture at different heights. The flow depth is measured by a laser device and a video camera takes images of the surface of the passing flow (Graf et al., 2018).

Special measurement campaigns have been performed to better understand certain aspects of the debris-flow process, such as channel-bed erosion and deposition (Berger et al., 2011), the use of infrasound to detect debris flows (Kogelnig et al., 2014; Schimmel et al., 2018), and advanced seismic methods to explore the formation of debris flows and their propagation along the channel (Walter et al., 2017). Several flexible ring-net barrier types were installed and tested in the channel bed at the Illgraben. The results have been used to improve the design of flexible debris-flow barriers (Wendeler et al., 2007). 
The flows detected by the monitoring system include both debris flows and debris floods. While the smallest debris flood mobilised several hundred cubic meters, the largest debris flow involved a volume of up to $150000 \mathrm{~m}^{3}$. A similar very high variability was observed for front velocity $(0.3-10 \mathrm{~m} / \mathrm{s})$, flow depth $(0.25-4.7 \mathrm{~m})$, discharge $\left(1.5-170 \mathrm{~m}^{3} / \mathrm{s}\right)$, composition (fines, solids, wood), water content (25-80\%) and density of the debris flows and floods (1300 - 2200 $\mathrm{kg} / \mathrm{m}^{3}$ ). The larger value of these parameters typically occurs in debris flows, whereas the lower limit is typically related to debris floods.

Hourly rainfall totals exceeding $8 \mathrm{~mm}$ or rainfall intensities larger than $2 \mathrm{~mm}$ in 10 minutes can trigger debris flows. The rainfall threshold was defined as $I_{t r}=5.4 D_{t r}{ }^{-0.79}$ (McArdell and Badoux, 2007; Badoux et al., 2009), where $I_{t r}$ and $D_{t r}$ were defined as the mean rainfall intensity and the rainfall duration until a debris flow is triggered (not the total rainfall duration, $D$, as used in the previously described sites). 


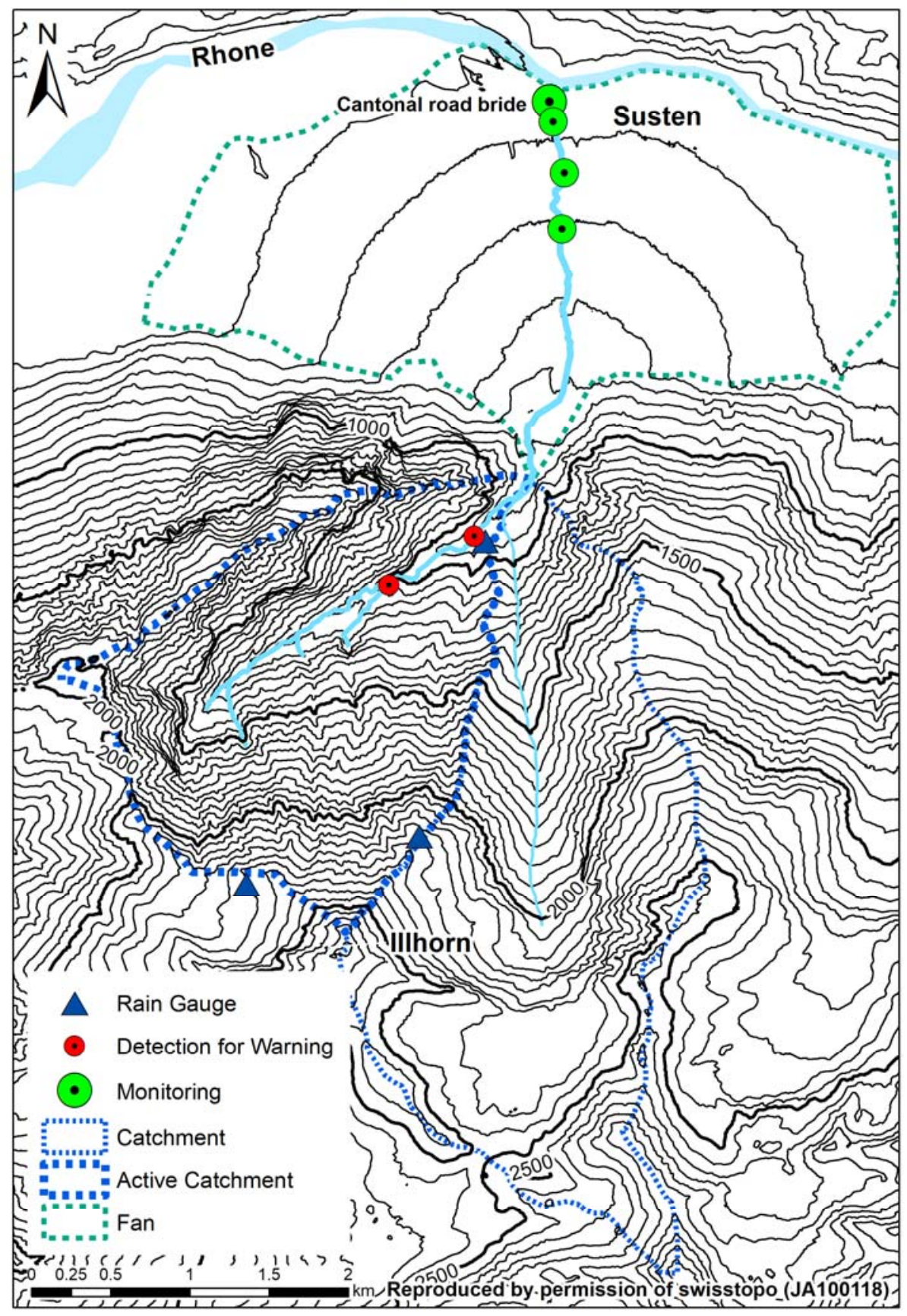

Figure 5: The Illgraben (Switzerland) monitoring site including four stations for monitoring on the fan, two detection stations for the warning in the active catchment and three rain gauges.

\subsubsection{Kamikamihori, Japan}

The Kamikamihori catchment is located on the east slope of Mt. Yakedake in central Japan. Field monitoring at Kamikamihori started in 1970 by a research partnership that was established between the Disaster Prevention Research Institute from Kyoto University and the Matsumoto Sabo Construction Office of the Ministry of Construction (Suwa et al., 2011). 
The catchment was selected as a debris-flow monitoring site because Mt. Yakedake had recently erupted in 1962. Since 1585, 27 eruptions have been recorded at this volcano (Global Volcanism Program, 2013) and lava domes still exist around the summit and deposits of pyroclastic flows cover the underlying andesite. The Kamikamihori torrent is the northernmost of four gullies on the east slope of Mt. Yakedake (Figure 6). The catchment ranges in elevation from 1490 to about $2300 \mathrm{~m}$ asl. The debris fan is situated adjacent to Azusa River. The catchment area and the channel length are $0.8 \mathrm{~km}^{2}$ and about $2.5 \mathrm{~km}$, respectively (Okano et al., 2012). The average gradient of the fan is $3.5^{\circ}$. The climate of the region is humid and temperate. The annual precipitation is approximately $2500 \mathrm{~mm}$ and a third of it falls as snow (Okano et al., 2012; Suwa et al., 2009). The catchment is generally covered with snow from November to April. Eight check dams were installed in the middle reach of the torrent from 1950s to 1970s, in order to prevent channel incision and reduce sediment transport into the Azusa River. Several kinds of new debris-flow protection measures have been tested in the Kamikamihori channel. For example, a flat-board debris-flow breaker was installed at the middle reach of the observation site (Gonda, 2009).

The monitoring system includes the "middle station" and the "source area station" (Figure 6). The main observation station (the "middle station") is located at $1580 \mathrm{~m}$ asl, where the channel bed slope is $8^{\circ}$. Electricity is supplied to this station by a power cable. The middle monitoring station utilises three video cameras, an ultrasonic stage gauge (Yokogawa Denshikiki Co. Ltd.), an electromagnetic velocity meter (Yokogawa Denshikiki Co. Ltd.), a seismometer (MS-335, Tokyo Sokushin Co. Ltd.), and a rain gauge (Suwa et al., 2009). A first seismometer was installed at the right bank of the channel and in 2010, it was replaced with a new one (LC4-3D, Sercel Inc.; Ohmi, 2016). The distance from the channel centre to the seismometer is $15 \mathrm{~m}$ (Suwa et al., 2000). Trip wire sensors are located at 30 points along the torrent at elevations ranging from 1500 to $1950 \mathrm{~m}$ asl. When a debris flow cuts multiple trip wire sensors, the monitoring system enters “eventmode" and begins recording at $1 \mathrm{~Hz}$. The trip wire sensors also record the time the debris flow passed each location. Thus, the mean flow velocity between the sensor locations can be estimated. These data are collected every second and stored at the middle station. Recently, new equipment consisting of a $2 \mathrm{~m} \mathrm{x} 4 \mathrm{~m}$ steel plate, four load cells, two pore-water pressure sensors, an ultrasonic surface velocity sensor, and an ultrasonic flow stage sensor (JFE Advantech Co. Ltd.) were installed at the middle station to obtain detailed information on the flow density and flow dynamics. This equipment is identical to that installed at a volcanic creek in southern Japan (Osaka et al., 2014) and similar to the system installed at the Illgraben (McArdell et al., 2007). Data from the load cells are continuously collected at $100 \mathrm{~Hz}$. To date, no data from the force plate sensors have been collected, because there have not been any significant debris flows since 2010 . The sensors of the source area monitoring station were operational until about 1999. At this station, rainfall, discharge at a small tributary, and the position of the groundwater table at three points in the channel bed were measured to investigate initiation processes of the debris flows (Suwa, 1989). The discharge was measured every minute using a V-notch weir with a float-type water level sensor. The three groundwater table sensors were installed at a depths of $1.2 \mathrm{~m}$ (Okuda et al., 1976).

The results of the hydrological investigations in the headwater indicate that debris flows were triggered by surface runoff eroding and incorporating channel sediment. This hypothesis was supported by monitoring data showing the rising water table and runoff in the tributary torrent - corresponding to debris-flows initiation (Suwa, 1989). Also, Okano et al. (2012) analysed rainfall conditions, discharge and video footage at the middle station for 14 debris-flow events and distinguished two types of debris flows. One type included large water-rich debris flows with high velocities that were triggered by rainfall of high intensities and large total precipitation. The other type included small debris flows with low to intermediate velocities that were triggered by rainfall with high intensities and smaller total precipitation. The debris flows typically had coarse-grained surge fronts (Suwa, 1992). Debris-flow velocities estimated by the wire sensors ranged from 6 to 16 
$\mathrm{m} / \mathrm{s}$ in the upper reaches with gradients of $14^{\circ}$ to $26^{\circ}$ and decreased to less than $4.5 \mathrm{~m} / \mathrm{s}$ at the monitoring station with bed slopes of about $8^{\circ}$ or less (Suwa et al., 2009). Debris flows occurred very frequently after the volcanic eruption in 1962. In 1969, before the beginning of monitoring, 13 debris flows were observed (Yamakoshi et al., 2001). The frequency of debris flows has declined since the 1980s. The decline in debris-flow frequency may be associated with vegetation recovery, which has increased the infiltration capacity of the soil and reduced runoff in the channels. As a result, the rainfall threshold for debris-flow triggering tended to increase in the 1980s (Suwa et al., 2009). The lowest 10-min rainfall intensity triggering debris flows was about $4 \mathrm{~mm} / 10$-min in 1970s, whereas the threshold was more than $7 \mathrm{~mm} / 10$-min in the 2000s (Suwa et al., 2009).

Comparison between hydrographs and the vertical components of seismic acceleration amplitudes for 34 debris flow surges revealed a positive linear correlation between peak discharge and peak amplitude of ground acceleration (Suwa et al., 2000). Total volume of debris flows and time-integrated acceleration amplitude also showed a linear positive correlation.

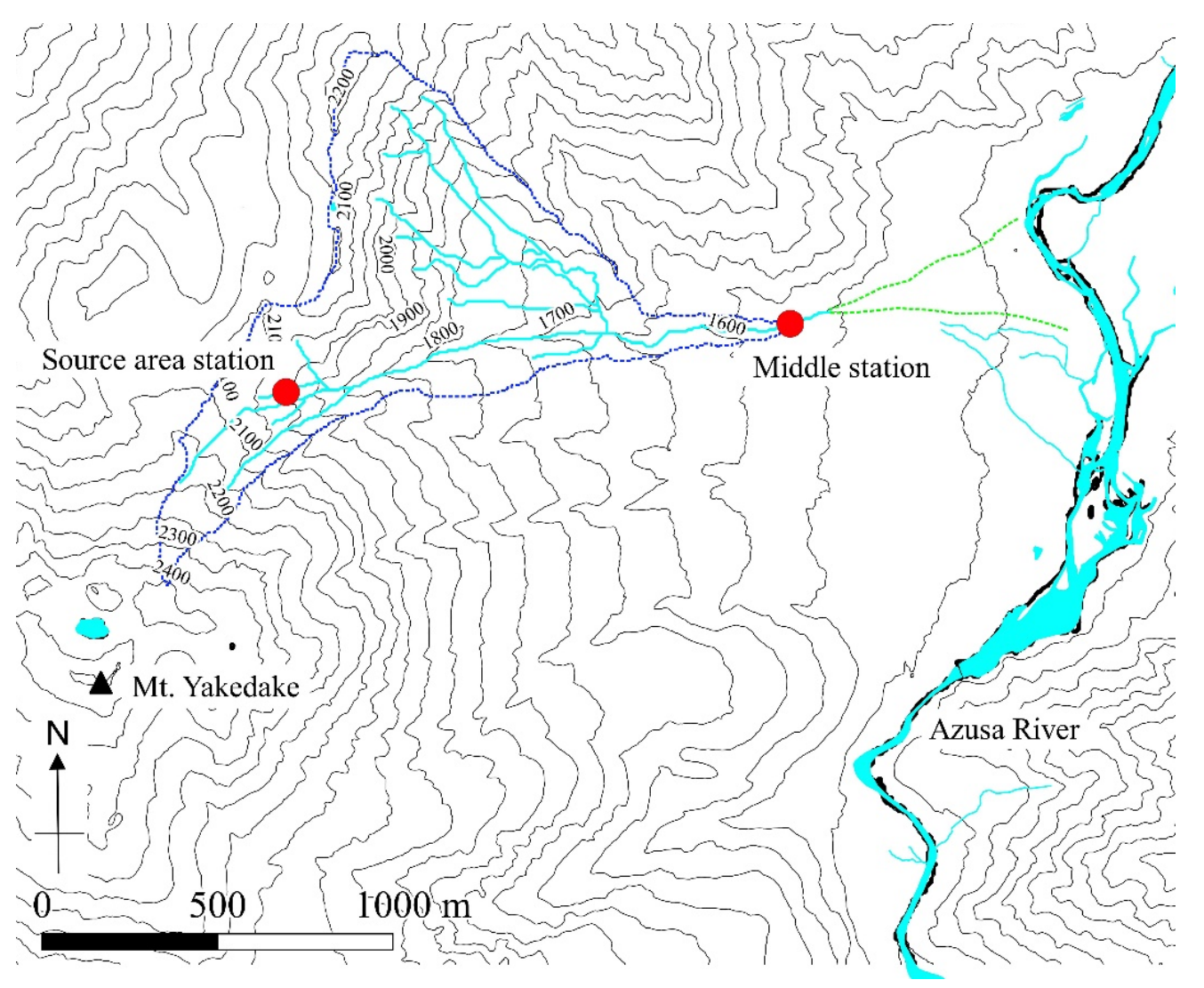

Figure 6: The Kamikamihori (Japan) monitoring site. Topographic map and location of the two monitoring stations.

\subsubsection{Lattenbach, Austria}

The Lattenbach creek (District of Landeck, Tyrol, Austria) is a very active torrent located in a geologic fault zone in the western part of Austria. The Lattenbach watershed has a catchment area of $5.3 \mathrm{~km}^{2}$ and is located west of the city of Landeck. The Lattenbach feeds the Sanna river, which is a tributary to the Inn River.

The highest elevation of the watershed is $2930 \mathrm{~m}$ asl, and the elevation of the outlet is $830 \mathrm{~m}$ asl. Geologically, the catchment is divided into a northern part, where materials of the Northern Limestone Alps crop out, and a southern part 
with materials of the Crystalline Alps (Geologische Bundesanstalt, 2010). The tectonic transition between these geologic units is marked by the incised channel of the Lattenbach (Wieser, 2004). Due to the tectonically strongly stressed rocks and often unfavourable bedding of the strata parallel to the hillslope, numerous mass movements have led to continuous mass-wasting processes. Hence, sediment transport processes in the Lattenbach are believed to be transport limited rather than supply limited.

Severe debris flows and debris-flood events at this site have been reported in 1911, 1912, 1925, 1944, 1949, 1965, 1966, 1973, 1998, 2005, 2007, 2010, 2015, 2016, 2017, and 2018 (Hübl et al., 2018). An analysis of available records from these events suggests that most were probably triggered by short-duration thunderstorms. Structural mitigation measures were constructed along the channel during the $20^{\text {th }}$ century. Since 1908 , approximately 33 check dams were built to stabilize the channel bed and to consolidate the slopes. However, a considerable number of them have been destroyed, in particular those situated in the middle reach of the catchment (Hübl et al., 2014).

The Lattenbach creek has been monitored by the Institute of Mountain Risk Engineering since 2002 because of frequent debris-flow and debris-flood events. The monitoring system consists of four stations (Figure 7): a meteorological station situated in the headwater (Dawinalpe), a monitoring station at the fan apex near the Pians village (at $1.5 \mathrm{~km}$ upstream from the outlet of the Lattenbach into the main river) and two other stations near the Grins village in the middle reach of the torrent (Grins I at $1.325 \mathrm{~km}$ and Grins II at $1.278 \mathrm{~km}$ ). The meteorological data (precipitation, temperature, humidity) at station Dawinalpe are measured every 10 minutes. At the two Grins stations, the flow stage is recorded continuously by radar sensors (VEGAPULS WL61) at three positions (2 Hz), while a 2D-laser scanner (LMS 511-20100, SICK) registers the flow surface topography at one cross section with a sampling rate of $5 \mathrm{~Hz}$. All the radar sensors monitor continuously (during "non-event" and "event mode") at the mentioned scan rates, while the 2D-laser scanner and the video camera turns on in the "event mode". When the system switches into event mode, alert messages are sent by SMS. This switch to event mode is performed, if one of the following conditions is met: i) one of the four trip wire switches that are installed upstream of the monitoring stations at Grins is broken, or ii) the recorded flow depth at the Grins II station is above $1 \mathrm{~m}$ for at least 5 seconds and/or there is an increase in the flow depth of $0.3 \mathrm{~m}$ between two recording intervals. In addition, the "MAss MOvement Detection and Identification System" (MAMODIS, Schimmel and Hübl, 2016) that consists of seismic and infrasound devices, can also trigger the $2 \mathrm{D}$-laser scanner. The surface velocities are continuously measured by a Doppler Pulse Compression Radar (SR1000-10-P, IPTB) within seven channel reaches of a length of $15 \mathrm{~m}$ each (Hübl et al., 2018). The seismic and infrasound emissions of the passing debris flows are recorded by one seismometer (LE-1D, LENNARTZ electronic GmbH), two geophones (SERCEL SG-5), and three infrasound sensors (WME 960H, MICROTECH GEFELL GmbH and electret KECG2742WBL-25-L, KINGSTATE) at 100 Hz. The discharge in the middle reach (Grins stations) is calculated from the product of measured flow cross-sectional area and flow velocities (mode of the surface velocity distribution) with averaged data for a time step of one second. The flow depth is also recorded at the Pians monitoring station. The Grins and Pians stations are equipped with a power supply of $220 \mathrm{~V}$ and data transmission occur by a GSM modem.

The results of the monitoring data reveal different aspects on the debris-flow initiation and flow behaviour. The triggering rainfall varies between 5 to $40 \mathrm{~mm}$ during 30 and 120 minutes, respectively. It appears that if a debris flow occurs within 24 hours after a previous one, the triggering rainfall threshold for the second debris flow is lower. A preliminary threshold is described by the formula $I_{t r}=14.23 D_{t r}{ }^{-0.63}$.

The rheological behaviour of the observed debris flows can be classified as muddy, although big boulders up to a diameter of $4 \mathrm{~m}$ can be transported downstream. Usually the debris flows are composed of an unsteady series of surges, lasting just several seconds to minutes and flowing at a velocity of up to $10 \mathrm{~m} / \mathrm{s}$ (Arai et al., 2013). Only the smaller debris flows 
consist of a single surge. Infrasonic signal analysis shows that the peak frequencies are in a range of 5 to $15 \mathrm{~Hz}$, whereas the seismic signals are in the range of 10 to $30 \mathrm{~Hz}$. Seismic and infrasound signals are correlated and provide a rough estimation of the flow type (debris flow, debris flood, flood) and magnitude (Schimmel et al., 2018).

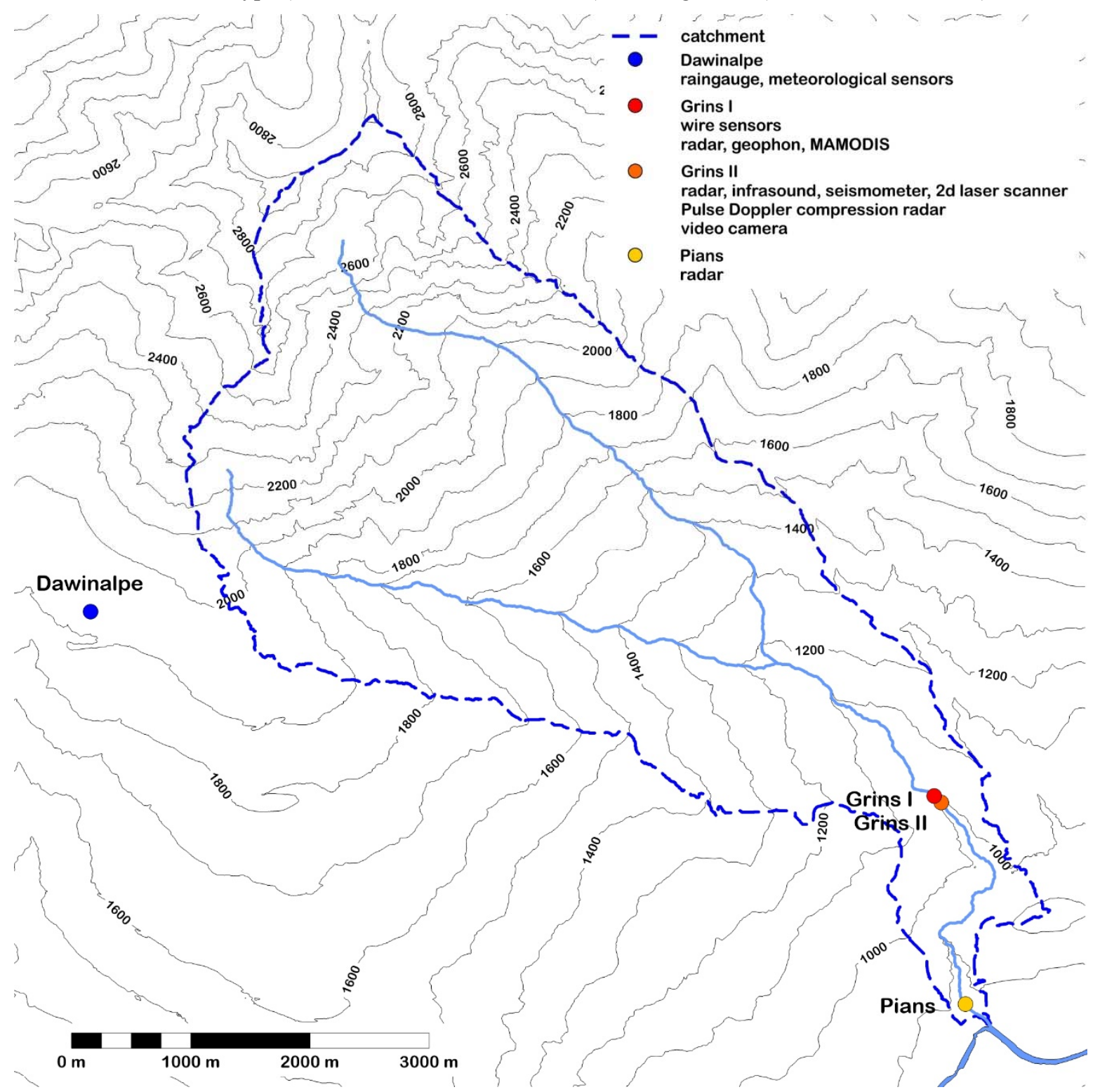

Figure 7: The Lattenbach (Austria) monitoring site. Topographic map and location of four monitoring stations

\subsubsection{Réal, France}

The Réal is an active torrent in the Southern French Prealps, which forms part of the Var River catchment. Debris-flow monitoring stations were installed in late 2010 by the French Research Institute Irstea (Navratil et al., 2013). Initially, three stations (S1, S2 and S3) were deployed along the channel (Figure 8) to investigate the initiation and the propagation of debris flows from hillslopes to the catchment outlet (Theule et al., 2015). Since June 2017, the middle reach station (S2) was removed to ease site maintenance. Each station detects the timing of flow and characterises the flow type. Station data have been used to complete an event database, including flow depth, surge velocity, peak discharge, volume and information on the triggering rainfall conditions (Bel, 2017). 
The drainage basin of the Réal Torrent has steep slopes (average value of $30^{\circ}$ ) and high sediment supply, which is delivered by severe erosion of the non-vegetated upper catchment. The non-vegetated area represents about $30 \%$ of the total basin and the denudation rate in the main scarp "Big Ravine" is about $14 \mathrm{~cm} / \mathrm{yr}$ (Liébault et al., 2015). The sediment source results from intense gullying in $100 \mathrm{~m}$ thick paraglacial deposits. Thus, the catchment has an almost unlimited sediment supply. The climate is mountainous and dominated by i) intense rainfall from convective storms from May to September, ii) long-lasting showers from September to December, and iii) snowfall from January to April. The mean annual precipitation is $1055 \mathrm{~mm}$, mostly concentrated in the spring and summer. Rainfalls are relatively heavy because of the Mediterranean influence with $112 \mathrm{~mm} / \mathrm{d}$ of annual daily-rainfall (10-yr return period) and 102 rainy days per year on average. The torrent contains eight check dams, built between 1933 and 1983. Exposed assets are limited and the main involving damages concern the grasslands and the obstruction of a ford across the Aliège road about once a year. The check dams span the entire channel width, and were regularly heightened, considering channel aggradation during the $20^{\text {th }}$ century. Currently, the check dams are totally or partially buried.

Each monitoring station is equipped with i) a tipping bucket rain gauge of 0.20-mm resolution (AGR100 Campbell), ii) an ultrasonic or radar flow stage sensor (US6 Paratronic or VEGAPULS WL S 61), iii) a set of vertical geophones (GS20DX Geospace) with custom-designed signal-conditioning boards, and iv) a photo-camera (CC640 Campbell or PC900 Reconyx). The data are recorded using an environmental datalogger (CR1000 Campbell) and stored in a compact flash module (CFM100 Campbell). Each monitoring station is powered by a 110 Ah battery attached to a $55 \mathrm{~W}$ solar panel. The geophones are fixed on boulders embedded in the banks outside of the active channel. Initially, at each station, three geophones were distributed along the channel at a distance of about $100 \mathrm{~m}$ from each other and were used to estimate the surge propagation velocity. Since June 2017, the arrangement of the geophone has evolved, as well as the homemade signal conditioning boards, in an attempt to better characterize flow type. Five geophones were placed at the upstream station (S1) and three at the downstream station (S3). Two of the geophones at each station were positioned on both sides of the cross section (one at the right and another at the left bank). Rainfall is totalized over a 5 min time step. A camera records an image once a day and every 4 to 10 seconds during rainfall events. Until June 2017, the flow stage and geophone data were recorded continuously with a $5 \mathrm{~Hz}$ sampling frequency. Since then, the system differentiates between "event mode" and "non-event mode" to optimise the storage capacity (allowing up to 10 months of autonomy). The switch to the "event mode" is done by the rainfall measurements and data are recorded during rainfall events at a $10 \mathrm{~Hz}$ sampling frequency. In addition to the high-frequency recording, rainfall, flow stage, battery state, and maximum geophone signals are recorded in the "non-event mode" every 5 minutes. A GSM communication system makes it possible to access the 5min data via a web interface, which is updated every night. The high-frequency data collected in "event mode", as well as the photos are stored in memory cards and downloaded during site maintenance operations.

The Réal Torrent is prone to bedload transports, debris floods and debris flows. The flow stage and the geophone signals can detect and distinguish the three types of flow (Bel, 2017). Although the debris-flow deposits have a granular appearance, they are muddy debris flows with a viscoplastic fluid, as highlighted by the grain-size analysis of the fine fraction of samples taken in non-leached deposits (Bonnet-Staub, 1998). Not all debris flows triggered in the source area propagate to the confluence with the Tuébi River. Comparison of observations at the three monitoring stations shows a decrease in debris-flow frequency with the drainage area. On average, about four debris flows per year are observed at the upper monitoring station (S1) near the sediment source areas, whereas about one debris flow per year is observed at the downstream monitoring station (S3) close to the basin outlet. The peak discharge estimates range from less than 1 $\mathrm{m}^{3} / \mathrm{s}$ to almost $100 \mathrm{~m}^{3} / \mathrm{s}$. The mobilized volume estimates range from $100 \mathrm{~m}^{3}$ to more than $10000 \mathrm{~m}^{3}$, which would correspond to relatively low magnitude events (Jakob, 2005). In the Réal Torrent, the intensity-duration threshold was 
estimated to be $I=10.29 \mathrm{D}^{-0.62}$ based on the debris flows detected at the downstream station close to the torrent outlet (Bel, 2017). Debris flows occur mainly in spring and summer during intense convective storms, but some events occur during snow melting periods. The 5 min maximum rainfall intensity, the cumulative rainfall, the $48 \mathrm{~h}$ antecedent rainfall, and the number of days elapsed since the end of winter (used as a proxy of sediment supply) were found to be statistically good predictors for debris-flow triggering in the vicinity of the sediment sources (Bel et al., 2017). However, the complexity of the flow response to rainfall was shown to increase with the catchment size.

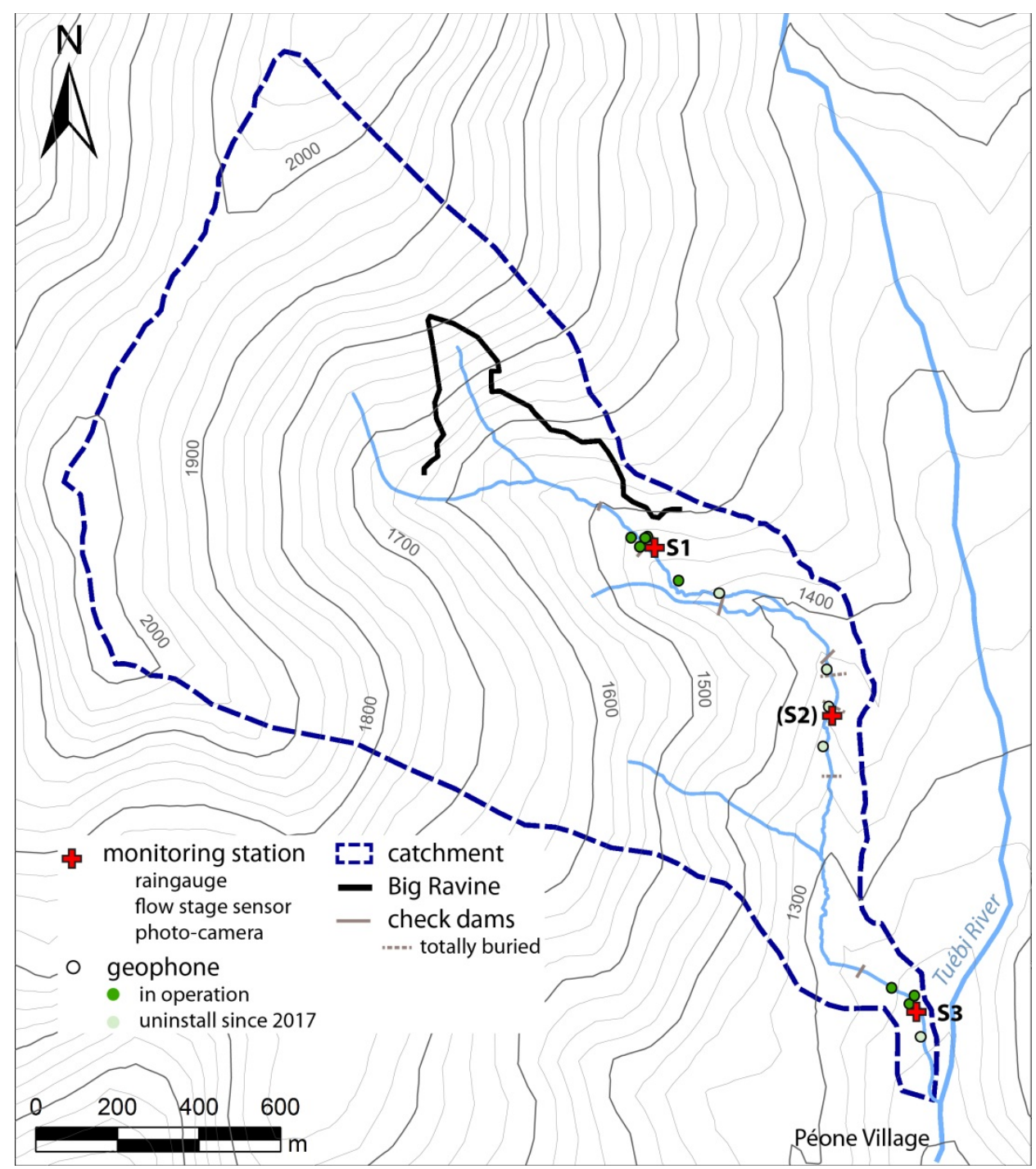

Figure 8: The Réal (France) monitoring site. Topographic map and location of monitoring stations (S1, S2 and S3) and near-channel geophones.

\subsubsection{Rebaixader, Spain}

The Rebaixader monitoring system is the most comprehensive site of three systems located in the Pyrenees. Monitoring in the basin focusses on debris-flow initiation and flow dynamics (Hürlimann et al., 2014), whereas the accumulation processes on the fan and the erosion in the source area are studied using geomatic techniques (Nuñez-Andrés et al., 2019). The major advantages of the Rebaixader catchment for monitoring are its high activity, its limited size, and the lack of 
protection measures. Thus, within a short distance of about $1 \mathrm{~km}$, debris-flow initiation, flow behaviour, and deposition processes can be observed under natural conditions.

The Rebaixader catchment covers a total area of $0.53 \mathrm{~km}^{2}$ and is located in the Axial Pyrenees. The bedrock consists of Paleozoic metamorphic rocks including Devonian slates and phyllites formed during the Hercynian orogeny (Muñoz, 1992). The initiation zone of the debris flows is situated in a large and steep open scarp, which is formed in a lateral moraine. The granular material of the large moraine provides abundant sediment availability. Downslope of the scarp, there is a sharply incised channel with a length of about $150 \mathrm{~m}$ and an average slope of $21^{\circ}$. The fan apex has an elevation of $\sim 1350 \mathrm{~m}$ asl and the debris fan covers an area of $0.09 \mathrm{~km}^{2}$. The fan is mostly vegetated by dense pine forest and the flows travel generally along the main active channel. The meteorological conditions of the Rebaixader catchment are influenced by three main factors: i) the vicinity of the Mediterranean Sea, ii) the west winds from the North Atlantic, and iii) the orographic effects of the mountains. The annual precipitation in the area ranges from 800 to $1200 \mathrm{~mm}$.

Monitoring began in the summer of 2009 with a simple set up by UPC BarcelonaTECH. Since that time, various sensors have been added to improve the system. Some of these sensors (e.g., seismic recording unit) were only installed temporally. Currently, the monitoring system includes five operational stations (Figure 9). The most important station focuses on the detection and analysis of flow dynamics and is called FLOW-WR. This station is located in the channel reach and includes five geophones (Geospace 20 DX), one ultrasonic stage device (Pepperl+Fuchs UC6000-30GMIUR2-V15), one radar stage device (VEGAPULS SR68), and a video camera (Mobotix MX-M12D-Sec-DNightD43N43). The system switches from the "non-event mode" (low frequency recording) to the "event mode" (high frequency recording) by a ground-vibration threshold (Abancó et al., 2012; Hürlimann et al., 2014). When the threshold is exceeded, the FLOW-WR station goes into "event mode" and samples sensors at $1 \mathrm{~Hz}$. In contrast, the other four stations, which monitor with the initiation processes (principally rainfall measurement and water infiltration into the soil), have a constant, 5-minute scan rate. The meteorological station METEO-CHA consists of a rain gauge (DECAGON ECRN-100) and an air temperature / relative air humidity sensor (Campbell Scientific CS215). In addition, a snow height sensor (Vegaplus WL61) is installed at the station METEO-TOP. Infiltration is measured at stations INF-SCARP1 and INF-SCARP2, which are situated in the highest part of the scarp (Figure 9). A total of 8 soil moisture sensors (Decagon 10HS), 2 water potential sensors (Decagon MPS-2) and 2 piezometers (Geosense VWP 3200) are installed at different depths at the two stations to measure the infiltration properties. The FLOW-WR and METEO-CHA stations are connected by cables to two Campbell Scientific dataloggers, whereas the two infiltration stations and METEO-TOP use a long-range wireless technique to telemeter data (Loadsensing LS-G6). All the data are delivered by GSM transmission to the university server. The power supply of the entire system is provided by multiple solar panels and batteries (Hürlimann et al., 2014).

The flows detected by the monitoring system are classified into debris flows and debris floods (hyperconcentrated flows) according to the characteristics defined in Hürlimann et al. (2014). They have a granular behaviour and the fine fraction (clay and silt) is less than 5-10\%. In addition, some rockfalls have also been detected (Hürlimann et al., 2012). On average, one debris flow and two debris floods per year have been observed at the Rebaixader site. Flow volumes range from about $100 \mathrm{~m}^{3}$ (smallest debris flood) up to about $16000 \mathrm{~m}^{3}$ (largest debris flow). The debris flows and debris floods are mostly triggered by convective rainstorms during summer (June to September), but some events have also occurred in spring (due to a combination of snowmelt and rainfall) and in autumn. The analysis of rainfall data reveals that both maximum hourly and 5-minute rainfall accumulations can be used to distinguish triggering from non-triggering rainfalls (Abancó et al., 2016). Hourly rainfall totals larger than about $10 \mathrm{~mm}$ can trigger debris flows. Recently, a new updated rainfall threshold comparing mean intensity and total duration was defined as $I=11 D^{-0.74}$ (Hürlimann et al., 2019). The 
flow behaviour of the observed debris flows is characterised by large peaks at the front, which are visible by the sharp increase of both the ground vibration and the flow depth. Video images show that large blocks of the glacial deposits (more than $2-3 \mathrm{~m}$ in diameter) are present in the debris-flow front.

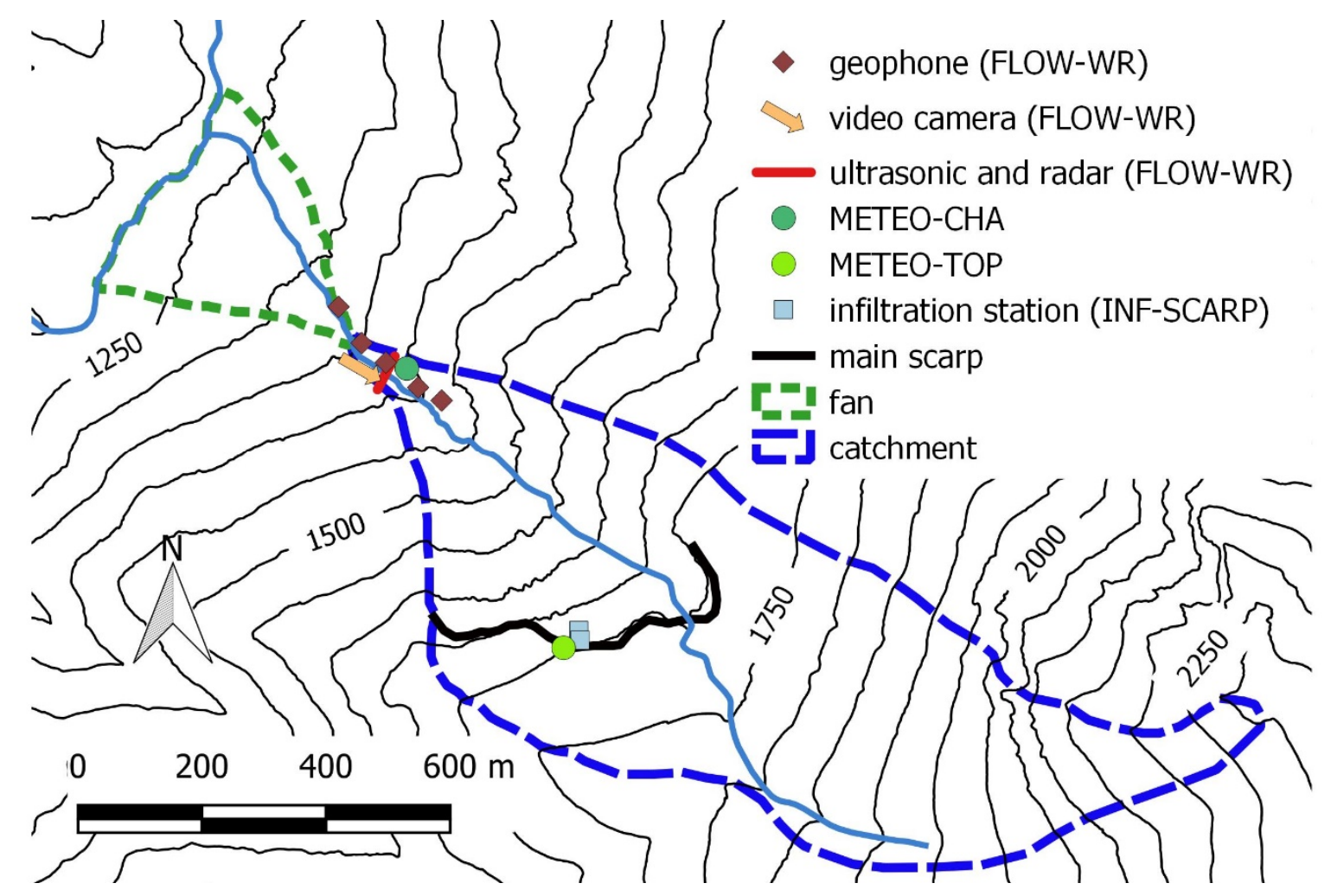

Figure 9: The Rebaixader (Spain) monitoring site. Topographic map and location of monitoring stations and the specific sensors of FLOW-WR station.

\subsubsection{Shenmu, Taiwan}

The Shenmu monitoring station is located in the Shenmu village, Nantou County in the central part of Taiwan, which is part of the Chen-Yu-Lan River watershed, the largest river system in Taiwan. This area was strongly affected by the 1999 Chi-Chi earthquake (Lin et al., 2006). Three potential debris-flow torrents merge together at Shenmu (the Aiyuzi, Huosa and Chushuei) and the entire drainage area encompasses $72.2 \mathrm{~km}^{2}$. Debris flows typically occur in the Aiyuzi torrent due to its steeper morphology (average bed slope of about $39^{\circ}$, Wei et al. 2018) and the large landslide areas in its catchment (almost $25 \%$ are affected by slope instabilities, Huang et al., 2013). The monitoring was established in 2002 by the Soil and Water Conservation Bureau of Taiwan, and since then 16 debris-flow events have occurred. The analysis of the recorded data principally focuses on issues regarding the warning of debris flows.

The geology of the Shenmu area mostly consists of Neogene sedimentary rocks (Lei et al., 2014). Landslides are the main initiation mechanism for the debris flows. Slope angles in the source areas of the debris flows are between 30 and $50^{\circ}$ and large parts of the watershed are affected by slope failures (Figure 10a). Due to the geologic conditions and the grain size distribution, the debris flows are classified as granular flows. In Nantou County, the annual average temperature is $20^{\circ} \mathrm{C}$ and the annual average rainfall is $2800 \mathrm{~mm}$. There were originally a few check dams and bank revetments at the site; however, these structures have since been destroyed by debris flows. Local government have tried to relocate the residents 
severely affected by the debris flows in recent years. Most of the residents have moved to a safe community, but some are still living in Shenmu.

The monitoring station is installed at $1187 \mathrm{~m}$ asl and includes different sensors to collect data principally focussing on debris-flow warning. The sensors can be classified into different types. One type, including trip wire sensors and geophones, detects the debris flows when they move down the channel. Another type, including rain gauges, sends alarms when the rainfall reaches a warning threshold. In addition, video cameras are installed to visualize and record, in realtime, the flow activity in the channel. The cameras are also used to determine if debris-flow warnings are correct or false alarms. Finally, soil moisture sensors provide information about the water content of the channel banks. The detailed layout of the monitoring system at Shenmu (Figure 10) includes two rain gauges (TK-1, Takeda Keiki Co.), two soil moisture sensors (AQUA-TEL-TDR, AUTOMATA), two geophones (GS-20 DX, Geospace), six trip wire sensors and four video cameras (PTZ Camera, AXIS; Huang et al., 2013). In addition, two broadband seismic sensors (Yardbird DF2, Academia Sinica Taiwan) are installed at Shenmu village (Huang et al., 2017).

The monitoring data are continuously recorded and transmitted to the Emergency Operation Center, EOC, in real-time for assistance in issuing debris-flow warning. The system measures continuously (during "event mode" and "non-event mode") the rainfall every minute, the soil moisture at $1 \mathrm{~Hz}$, the ground vibration from geophones at $500 \mathrm{~Hz}$ and the signals from broadband seismic sensors at $240 \mathrm{~Hz}$. Due to the large amount of seismic data, they are recorded in a local hard disc and kept for one month before overwriting. The data are processed on-site and energy of the seismic signals is calculated every minute. This value is transmitted to the EOC in real-time. The system switches to the event mode when the rainfall exceeds $10 \mathrm{~mm} / \mathrm{hr}$ or $100 \mathrm{~mm} / 24 \mathrm{hr}$. When event mode is triggered, the system turns on the video cameras, while all the other sensors continue measuring at the same sampling rate. An internet connection, Asymmetric Digital Subscriber Line $(A D S L)$, is the primary communication method, and satellite telemetry is used when ADSL is not working. If the main power supply is interrupted during a typhoon or heavy rainfall event, the power generator will start automatically and provide emergency power lasting for at least 5 days.

The analysis of the 16 debris flows recorded at Shenmu showed promising results on the triggering conditions and the flow behaviour (Huang et al., 2013, 2017). The rainfall is the basis of the debris-flow warning in Taiwan and thus of great importance. The Rainfall Triggering Index, RTI, is the product of the intensity, $I$, and the effective accumulated rainfall, $R_{t}$ (Jan et al., 2003). Based on RTI data of all the events collected in Taiwan, the rainfall threshold is defined by $R_{t}$, which is divided into nine levels from $200 \mathrm{~mm}$ to $600 \mathrm{~mm}$ with constant intervals of $50 \mathrm{~mm}$. In Shenmu, the warning threshold of effective accumulated rainfall is $250 \mathrm{~mm}$. In order to improve the accuracy of debris-flow warning in the future, the soil moisture data have been investigated. Time series obtained at the Shenmu and other monitoring stations show a clear relation between effective rainfall and soil moisture (Tsai et al., 2014). The seismic signals are not used for official warnings but provide additional information for the EOC officers. The analysis of past events shows that the geophones detected debris flows a few minutes before their arrival at the monitoring station (Huang et al., 2016; Huang et al., 2017). In addition and for research purpose, the ground vibration data from the geophones were processed using Fast Fourier and Harr wavelet transform. The results revealed that the main signal was between 0 and $31.25 \mathrm{~Hz}$. The low frequency range (between 10 and $40 \mathrm{~Hz}$ ) is used as debris-flow characteristic frequency (Huang et al., 2017). The broadband signals showed that the frequency of debris-flow fronts was usually even lower (between 0 and $10 \mathrm{~Hz}$ ). The lower frequency portion of the broadband signals were recorded earlier than the ones registered at the geophones. All these results indicate that geophones and broadband seismographs are useful for debris-flow warning. According to the case histories and based on the video recordings, the velocity of debris flows is estimated between 4.0 to $5.0 \mathrm{~m} / \mathrm{sec}$ in Shenmu (Huang et al., 2013). 
a)

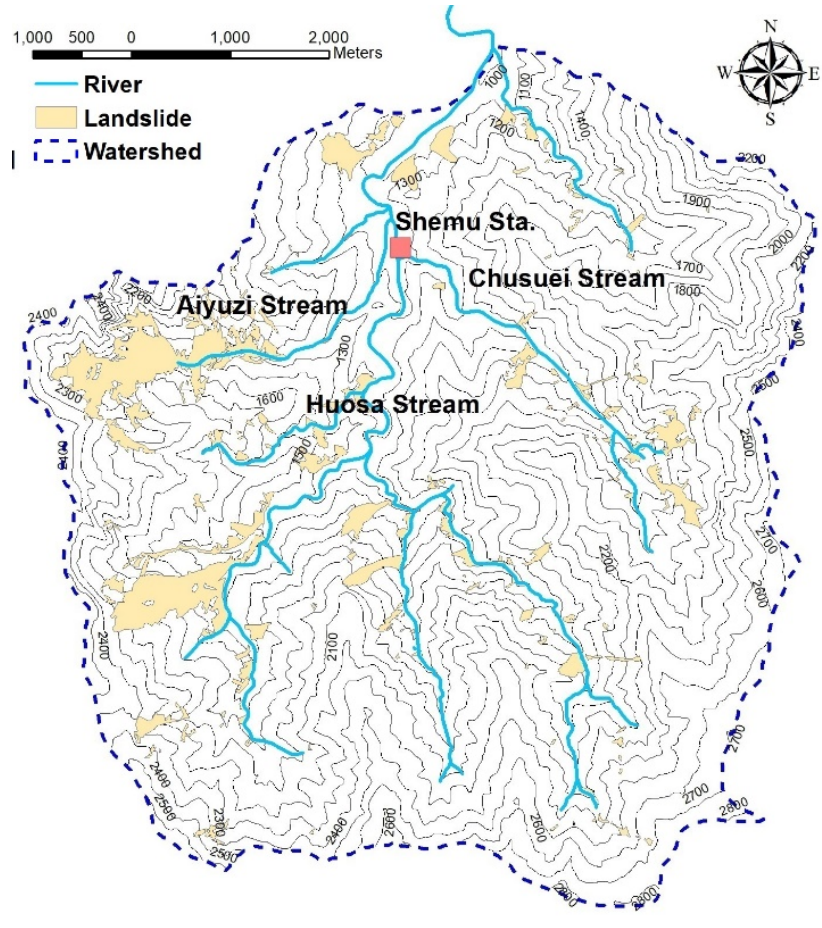

b)

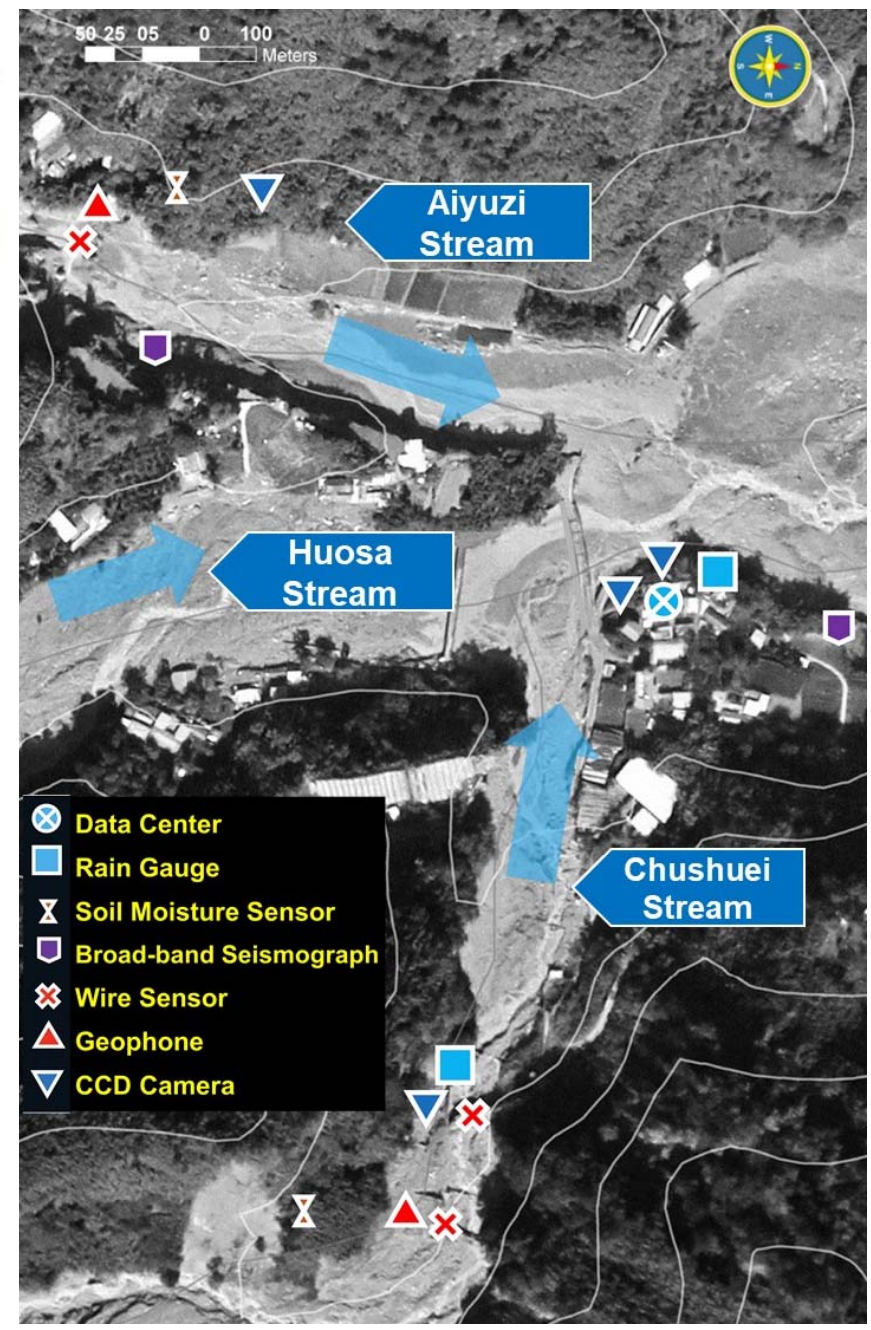

Figure 10: The Shenmu (Taiwan) monitoring site. a) Topographic map and location of the monitoring station at the confluence of the three debris-flow streams (after Lei et al., 2014). b) The layout of sensors installed at the Shenmu monitoring station. 


\section{Comparison of general features}

In this section, we compare and discuss some general characteristics of the nine monitoring sites. First, morphometric parameters as well as the different grain-size distribution curves of debris-flows deposits are evaluated. Then, some monitoring results are assessed including the debris-flow volumes and the rainfall thresholds. All these data provide useful information about the characteristics of the nine different sites that can aid in the design of new monitoring systems and help in the selection of suitable catchments.

\subsection{Morphometric parameters}

Morphometric parameters, such as basin area and fan slope, can provide important information regarding debris-flow susceptibility (Bardou, 2002; Wilford et al., 2004; Bertrand et al., 2013). These parameters can be easily derived from topographic information and are widely used for hazard susceptibility mapping (i.e., identifying debris-flow prone catchments). By using indicators of basin and fan morphologies, there are several classifications differentiating drainage basins according to their dominant flow type. Recognition of the principal hydro-geomorphic process of a particular basin is of paramount importance in the early stages of land use planning, in order to develop appropriate management strategies and to design protection works. Indeed, each process has different characteristics (e.g., peak discharge) that correspond with different damage potential.

Here, we compare the Melton index with the fan slope of the nine monitoring sites (Figure 11). Melton index is the ratio of the basin relief (difference between the maximum elevation of the basin and the elevation of the fan apex) by the square root of basin area. It provides an index of the available gravitational energy of the catchment. Fan slope is representative of the dominant transport process occurring from past flows. For the two largest basins, Shenmu (Sh) and Ergou (Er), the data of the most active sub-basins are also plotted, since results of these sub-basins are more representative and better correspond to actual site conditions. In addition, three existing classifications are included in the plot (Bardou, 2002; Wilford et al., 2004; Bertrand et al., 2013). Bardou (2002) divides the catchments into three different classes regarding the dominant process (fluvial, mixed and debris flow), while the other two studies distinguish only between fluvial processes and debris flows. In contrast to Wilford et al. (2004), Bertrand et al. (2013) include debris floods with fluvial processes. The classifications of Bardou (2002) and Wilford et al. (2004) rely on regional databases with dozens of basins, while Bertrand et al. (2013) is based on a global database of 620 basins.

Our results suggest that most of the nine monitoring sites are, unsurprisingly, characterised by a mixed and/or debris-flow regime using the three classifications. The Shenmu site (regarding the entire catchment with abbreviation Sh) is defined as a fluvial catchment by the method of Wilford et al. (2004). However, it should be noted that Shenmu is a special case because it is the largest basin and also lacks a fan (thus, the downstream channel slope was used as an estimation). The Shenmu sub-basin, Aiyuzi (Sh-A), is correctly classified by the three classifications, which argues for a size effect (Melton index is strongly influenced by the drainage area: the larger the basin, the smaller the Melton index). The Rebaixader catchment (Reb) is the only site with a clear debris-flow morphology in Figure 11, as both values (Melton index and fan slope) are very high. However, field monitoring shows that it is also prone to debris floods. In conclusion, these results highlight the good predictive capability of such classifications, whether global or regional, and their relevance regarding hazard assessment. The unique threshold for the Melton index designed by Wilford et al. (2004) reaches a limit for large basins, although the largest basins considered here are in the range of their database used for establishing the classification. The fluvial boundaries of the two other classifications, which depend on both the Melton index and the slope, appear appropriate here. The boundary proposed for distinguishing clear debris-flow morphology by Bardou (2002) is more uncertain. Indeed, as Bardou (2002) states, the establishment of such a boundary is challenging and observations of fluvial 
events in debris-flow prone catchments are difficult to gather, because they do not cause significant damages. Field monitoring, in particular, the combined use of video cameras and ground vibration sensors, may bring new elements to differentiate between fluvial, debris-flood and debris-flow processes, thus overcoming the uncertainties that exist in current classification systems.

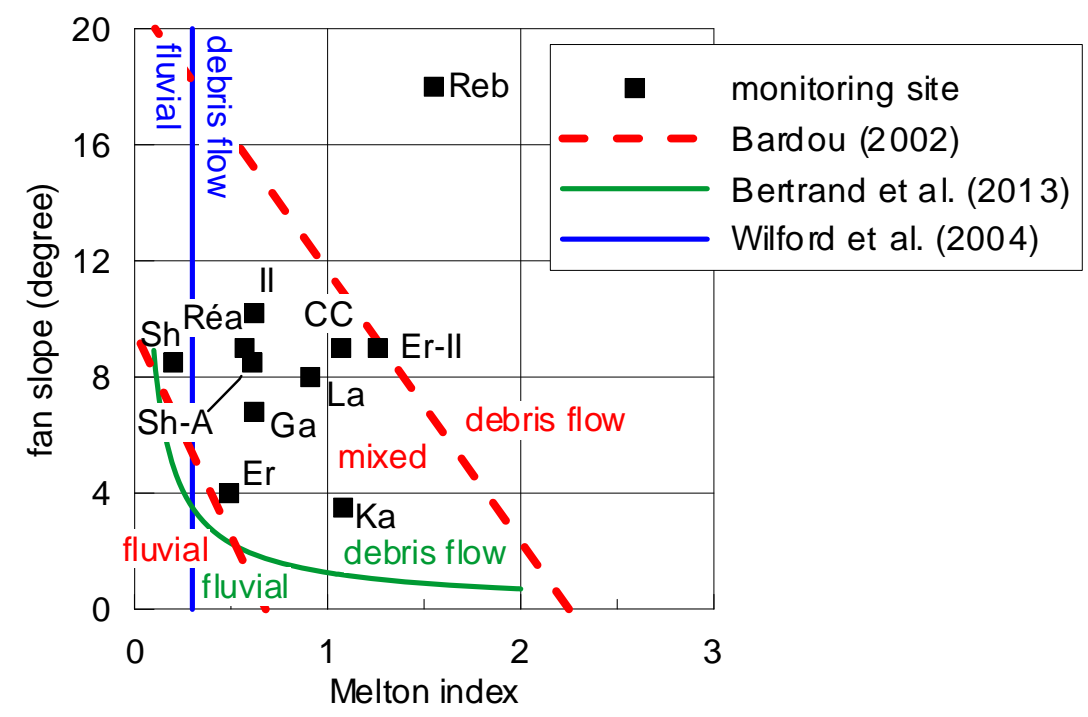

Figure 11: Comparison of the nine monitoring sites with existing classifications that differentiate the drainage basins according to the dominant flow type using Melton index and fan slope. The red dashed line indicates the classification proposed for the Canton Wallis, Switzerland (Bardou, 2002); the blue line indicates the one proposed for west central British Columbia, Canada (Wilford et al., 2004); and the green line shows the classification established from a large database compilation of the literature worldwide (Bertrand et al., 2013). See text for detailed explanation and Table 2 for abbreviated labels of the sites.

\subsection{Grain-size distributions}

The grain-size distribution, GSD, of the fine fraction $(0.002-20 \mathrm{~mm})$ is known to be characteristic of the mechanical properties of debris flows (Bardou et al. 2003). The discrimination between different rheological behaviour is an important issue in hazard assessment, because it helps practitioners choose an appropriate rheological law when conducting sitespecific hazard zoning.

We compare here the GSD of the nine sites. The GSD-curves were obtained from samples of the matrix of debris-flow accumulations in each catchment and the initial data included particle diameters between $0.002 \mathrm{~mm}$ and $96 \mathrm{~mm}$. Figure 12 shows the GSD-curves with a maximum grain size of $20 \mathrm{~mm}$. This normalization facilitates the evaluation of the different curves and also enables a comparison with the classification proposed by Bardou et al. (2003) that divides debrisflow samples into main rheo-physical classes. They propose that on one side there is the viscoplastic class, which generates debris flows with a Herschel-Bulkley or Bingham flow behaviour. Such events can also be called muddy debris flows. On the other side there is the collisional-frictional class, which has a Coulomb-like flow behaviour. Many times, these debris flows are called granular or stony debris flows.

The comparison of the nine GSD-curves shows that a clear distinction between classes can be difficult. According to the criteria of Bardou et al. (2003), the Illgraben (Il), Réal (Réa), Kamikamihori (Ka), and Lattenbach (La) may be classified by a viscoplastic flow regime based on the GSD, while Ergou (Er), Shenmu (Sh), Rebaixader (Reb), and Chalk Cliffs (CC) fit better within the collisional-frictional regime. At Gadria (Ga), no clear classification is possible, which is supported by the two non-aligned GSD-curves plotted for this site (Ga1 and Ga2, both related to a 2013 debris flow). The 
difficulty of a clear classification at Gadria has also been noticed in the video footage, since different flow regimes were observed ranging from very collisional (main front) to very viscoplastic (subsequent surges) during the same debris-flow event (Theule et al., 2018). Similar observations have been made at other sites (e.g., Illgraben or Réal) and show that the GSD of a debris-flow deposit is only a factor in determining flow behaviour. Additional information is necessary to definitively determine the dominant flow regime. Also, different debris-flow types may not only occur in the same catchment, but also during a single event; for example, the flow-regime change may arise both over time and/or in space during the flow propagation. The example from Gadria shows that monitoring data (video and seismic signals in particular) may help to characterise the flow regime at given locations during an event (Coviello et al., 2019a).

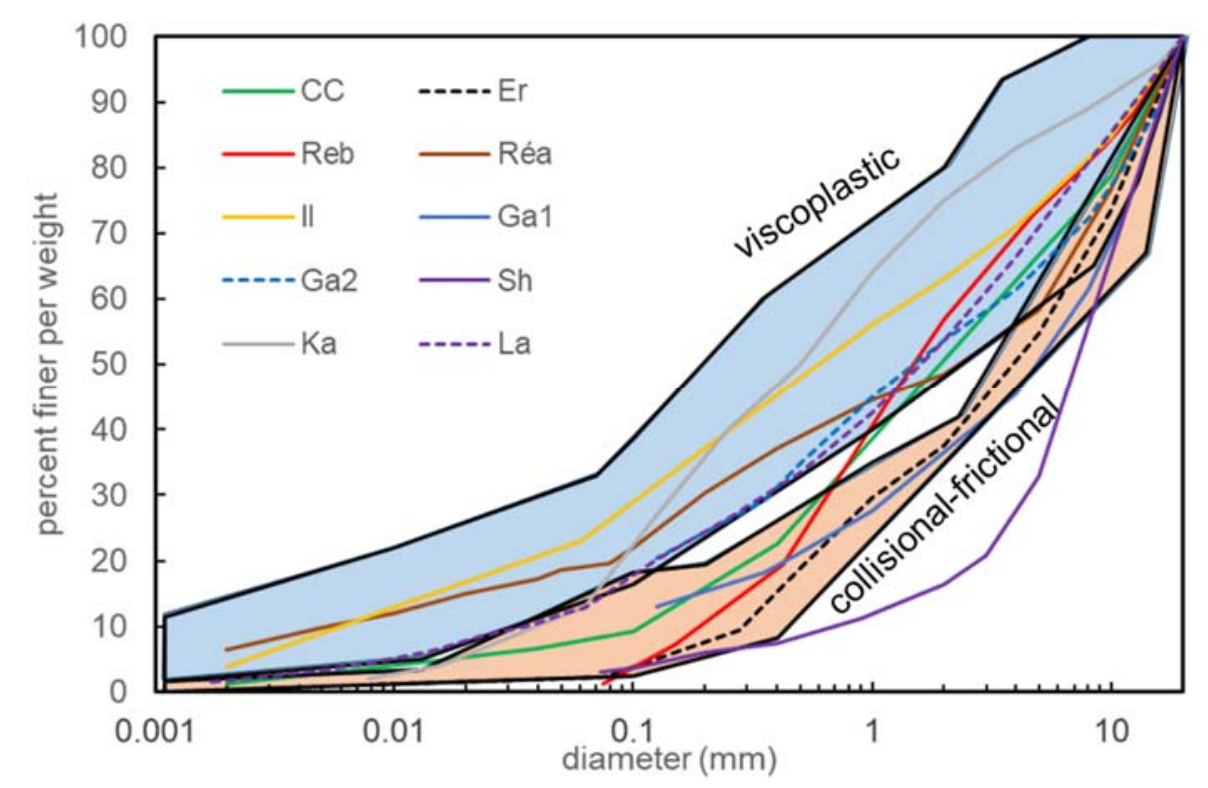

Figure 12: Grain-size distributions of debris-flow deposits sampled at the nine monitoring sites. The two main rheological classes proposed by Bardou et al. (2003) are added for comparison (blue coloured area indicates the viscoplastic regime and light-brown area the collisional-frictional regime). See text and Table 2 for abbreviations of sites.

\subsection{Drainage basin - debris-flow magnitude relationship}

Another useful relationship, especially for preliminary hazard assessments, compares the area of the drainage basin with the debris-flow volume. Indeed, the estimation of debris-flow volume, which is inherently linked with peak discharge and runout distance, is a fundamental element needed for the design of mitigation structures and hazard assessment (Rickenmann, 1999).

Here, we plotted the drainage areas and the volume estimates calculated from the monitoring station recordings for the nine sites worldwide (Figure 13), and compared them with the relationships proposed by D'Agostino and Marchi (2001) and Marchi et al. (2018). Although the debris-flow volumes can be accurately determined at the monitoring sites, there are still some uncertainties. Debris flows may have deposited upstream of the monitoring station (as observed at Kamikamihori, Ka) or they may have increased volume after passing the measuring point (Chalk Cliffs, CC; Réal, Réa, and Rebaixader, Reb) and therefore the final volumes might be underestimated. Nevertheless, the data from the nine monitoring sites support the hypothesis of the positive correlation between basin area and the magnitude of debris flows. One can notice that for a given catchment, the range of volume estimates may span several orders of magnitude. The maximum and the average volumes of the nine sites, as well the minimum volumes of the largest basins are in between 
the limits of D'Agostino and Marchi (2001). The volume ranges are encompassed by the 2nd and 98th percentiles proposed by Marchi et al. (2018) and the best-fit trend line calculated by the average volume matches rather well the 50th percentile line. Only the Ergou basin (Er) and its sub-basin Er-WII have considerably higher debris-flow volumes. This circumstance might be explained by the fact that only large events reach this station or by the short monitoring period (2014-2016).

Finally, the comparison of the nine basins with the cited relationships, established in eastern Italian Alps, highlights their relevance for worldwide applications. The datasets on debris-flow volume used by D'Agostino and Marchi (2001) were based on historical data and post-event surveys, which often only report the largest events (i.e., those responsible for damages). Marchi et al. (2018) included additional events from instrumented catchments, which allow the recording of large and small events. This likely explains why the smallest events observed at our monitoring sites are better represented by their 2 nd percentile line.

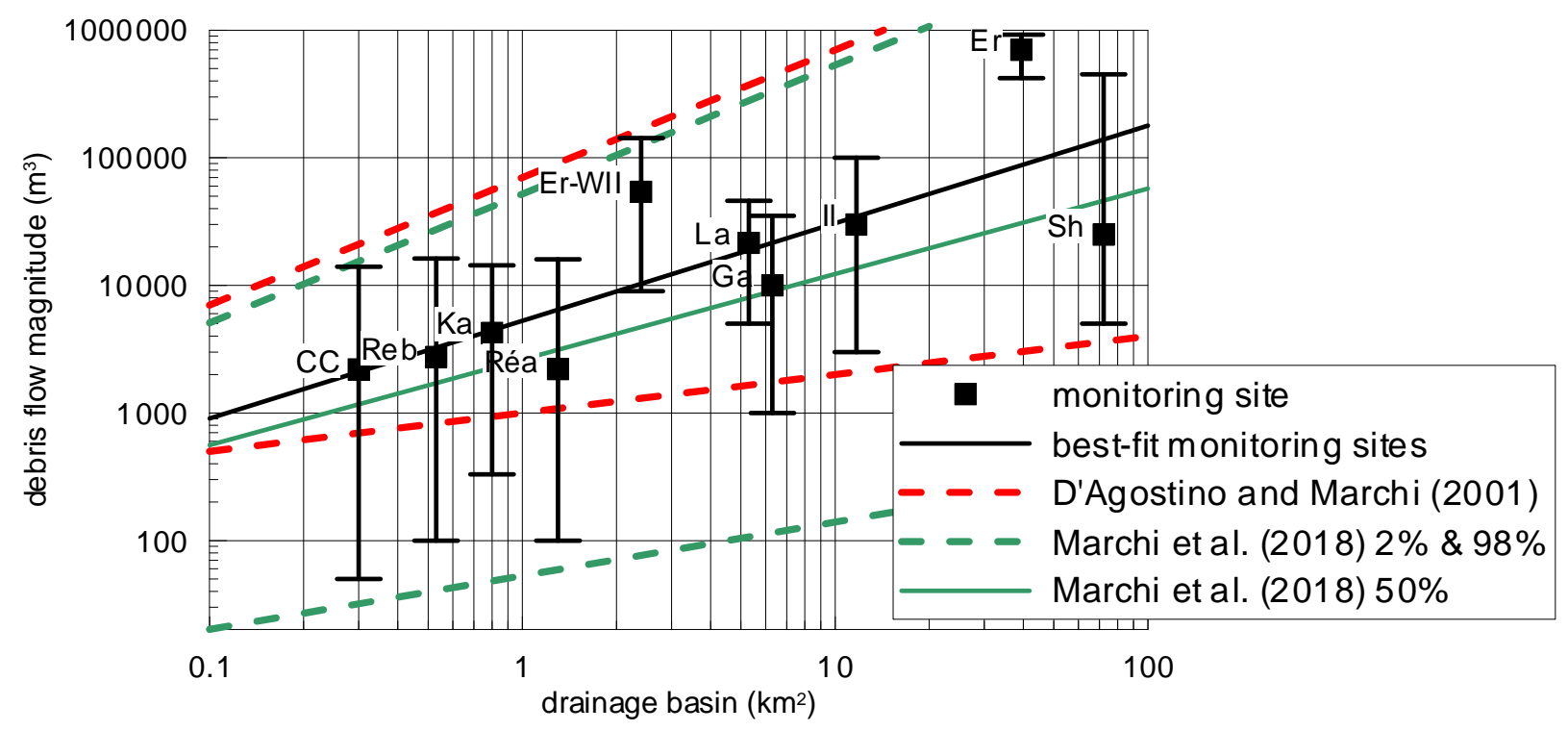

Figure 13: Relation between the drainage basin area and the debris-flow magnitude (volume) observed at the monitoring sites. Average volumes are plotted and error bars show the minimum and maximum values The red dashed lines indicate the limits proposed for the Eastern Italian Alps (D'Agostino and Marchi, 2001) and green lines show the relations (2nd, 50th and 98th percentile) from an updated database (Marchi et al. 2018). Abbreviation of the monitoring sites are listed in Table 2.

\subsection{Rainfall thresholds}

Characterising minimum conditions for debris-flow triggering through the definition of rainfall thresholds is a widely accepted methodology. Rainfall thresholds can improve the current knowledge about debris-flow initiation and may have practical applications in the predetermination of risk levels and in event forecasting. However, they suffer from high variability, in particular due to regional differences (climatic conditions, morphometric parameters, vegetation cover, geology, torrent control) and predisposing factors related to the recent history of the catchment (antecedent rainfalls, sediment availability, etc.). As a consequence, rainfall thresholds are typically site-specific and may evolve over time following events such as fire, earthquake or volcanic eruption. Comparing rainfall thresholds across monitoring sites might help to better understand controlling factors.

In seven of the nine monitoring sites, a threshold was determined using the relationship between the duration of rainfall, $D$, and the mean intensity, $I$. The thresholds at Illgraben (Il) and Lattenbach (La) were defined using the duration and 
corresponding rainfall until the debris-flow triggering, whereas the other sites use the total rainfall duration. In Kamikamihori (Ka) and Shenmu (Sh), the $I-D$ relationship was not defined, but the critical rainfall amounts for a duration of 10 minutes and 1 hour were identified. The comparison of both threshold curves and the critical rainfall points shows that the resultant triggering values are rather similar, except for Ergou (Er) where considerably higher rainfall is necessary to trigger debris flows (Figure 14). Debris flows are normally triggered by short duration and high-intensity rainstorms (Wieczorek and Glade, 2005) and the results from the monitoring sites show that the critical rainfall amount for a duration of one hour is between $5.4 \mathrm{~mm}$ (Illgraben) and $14 \mathrm{~mm}$ (Lattenbach) for the European sites, $7 \mathrm{~mm}$ for Chalk Cliffs, $15 \mathrm{~mm}$ for Kamikamihori, $22 \mathrm{~mm}$ for Shenmu, and finally $66 \mathrm{~mm}$ for Ergou. A positive relation between the hourly rainfall amount and the area of the drainage basin is observed, and therefore shows a possible scale effect, which should be considered in future investigations.

One should note that the $I-D$ threshold of Ergou shortly after 2008 Wenchuan earthquake was very similar to those of the other monitoring sites (see curve called "Er*" in Figure 14). The higher current threshold at Ergou (Er) may have multiple explanations. First, the drainage basin of Ergou is very large, and some smaller debris flows may have deposited upstream of the monitoring station. Consequently, only the largest events, which are likely triggered by the most intense rainfall, were detected. Second, a large earthquake such as the 2008 Wenchuan earthquake is known to provide new material sources and increase slope instability. So, one may suppose that following the earthquake, Ergou sediment availability was much higher, and for a time was supply unlimited, like the other monitoring sites. Furthermore, the susceptible sediment may have been stabilized with the recovered vegetation, explaining the higher threshold. Lastly, the time series available for Ergou is short (2014-2016) and perhaps insufficient for characterising the range of debris-flow initiating rainfall possibilities. As in a post-earthquake period, a similar disturbance of the sediment availability also occurs after a volcanic eruption (Major et al., 2016; Vázquez et al., 2016). However, no detailed data are available at Kamikamihori site to examine this hypothesis.

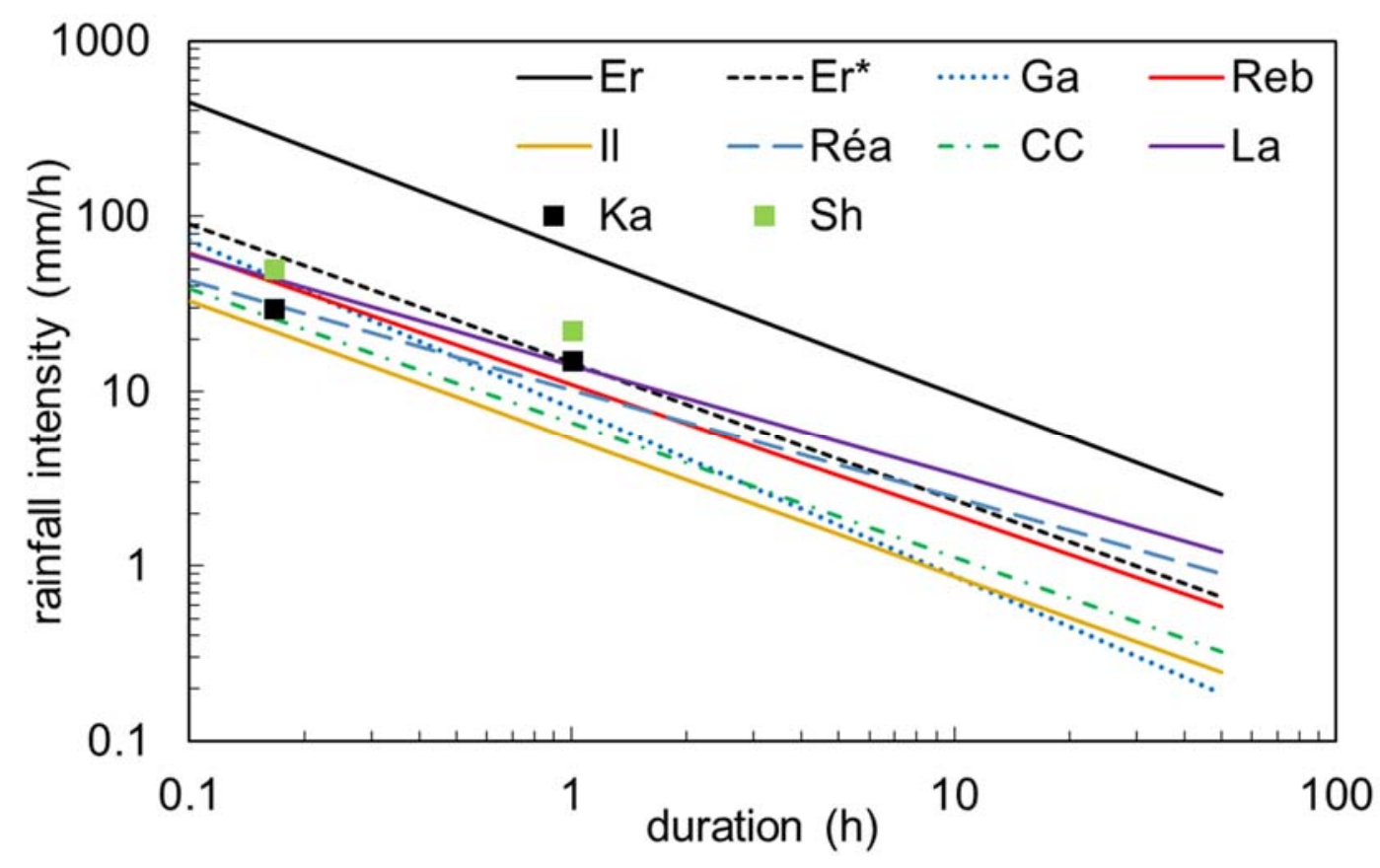

Figure 14: Comparison between mean rainfall intensity and total duration threshold curves of the monitoring sites. See Table 2 for abbreviations of sites. The Er* stands for threshold defined under post-earthquake condition at Ergou (Guo et al. 2016b). 
Monitoring stations, by detecting debris-flow events and recording rainfall information in close proximity to the triggering zone, make it possible to establish relevant local $I-D$ thresholds. Although the I-D thresholds of the nine monitoring sites are similar, they present some variability. Some of this variability is likely attributed to the methodology used to define the threshold (total rainfall or rainfall until the debris-flow triggering, time-series length, number of debris flows considered, criterion used to define the rainfall duration, etc.). This aside, the variability highlights that it is not possible to define a unique threshold even for supply-unlimited systems, which are typical of the monitoring sites. Since the relationship between rainfall and debris flow triggering is highly complex and nonlinear, other factors must be considered, in particular local hydrological conditions (e.g., soil moisture), slope morphology, and vegetation cover. Moreover, rainfall thresholds strongly depend on the initiation process; for instance, antecedent precipitation is important for landslide-triggered debris flows, but less for debris flows initiated by surface runoff (see Section 2.3). In our nine sites, debris flows are mostly triggered by surface runoff. In addition, the thresholds may be subject to temporal changes because of the variability of environmental factors such as vegetation or soil use. In this respect, the temporal variation of rainfall thresholds can bring new insight into catchment evolution. For instance, if we are able to characterise what changed in the catchment leading to debris flow, e.g., the vegetation cover, one can measure its effect on the threshold, by changing only one factor at a time (i.e., same climate, same morphometric parameters, same number of check dams, etc.).

Local rainfall thresholds may be used for warning and alarm systems such as the one in Illgraben (Badoux et al. 2009). However, it is not possible to instrument all the exposed catchments with sensor systems. Thus, early warning systems (EWSs) operating at national or regional scale have become better developed (e.g., Baum and Godt 2010, Segoni et al. 2015, Berenguer et al. 2015). EWSs may combine susceptibility maps and rainfall measurements or forecasts, and the definition of the warning level depends on the exceedance of rainfall thresholds. As a consequence, the characterisation of debris-flow triggering conditions at regional scale (i.e., explaining the regional variability of the thresholds) still remains an important issue.

\section{Final remarks}

Monitoring is an important task and improves our understanding of complex debris-flow related phenomena. The recorded data can be used for multiples purposes: i) to improve the knowledge of initiation mechanisms and flow dynamics, ii) to develop, calibrate and validate numerical models and their parameters, iii) to design both structural and non-structural mitigation measures, iv) to assemble early warning and alarm systems, and v) to evaluate hazard-related parameters like flow magnitude, discharge, velocity or frequency. The following points emerge as key concerns from our literature review and from the analysis of nine instrumented sites.

1. In many areas, debris-flow monitoring for research purposes is intrinsically linked to operational implications, since the approaches and outcomes are similar for each. Alarm systems are already operational in four of the presented sites (Gadria, Illgraben, Lattenbach, and Shenmu). Switzerland has installed more than a dozen debris-flow alarm systems, but there are also many others installed in Italy, Japan, Taiwan, and Austria (Hikida et al., 2007; Badoux et al., 2009; Tobler et al., 2014; Arattano et al., 2015; Schimmel et al., 2018; Wei et al., 2018). These systems are devoted to the automatic detection of debris flows based on a linear array of sensors, typically flow stage sensors, geophones or trip wires, installed along a channel reach located upstream of the infrastructure at risk. One of the key challenges for operational debris-flow alarm systems is that the lead-time is very short: for example, some tens of seconds for closing a transportation route or tens of minutes for evacuating settlements. Therefore, the rapid recognition and the 
identification of the correct process (flood, hypercontentrated flow or debris flow) by means of an automatic evaluation is crucial, as the damage potential of each process is different.

2. Monitoring systems can provide valuable information on critical rainfall conditions, which are commonly used in early warning systems. However, warning systems based on rainfall thresholds are affected by large uncertainties due to the high spatio-temporal variability of storm cells and because of the effects of secondary controls (i.e., snowmelt, antecedent soil moisture, sediment availability) on debris-flow initiation. The combination of a high rain gauge density with complementary monitoring data enables the reduction of the uncertainties related to the spatial representativeness of rainfall measurements. Moreover, precise knowledge of the time of occurrence may enable recognition of progressively finer details, such as which part or phase of a rainstorm actually triggered the debris flow. The combination of rainfall measurements in the upper part of the catchment for early warning and instrumental detection of channelized flows in the lower part for alarm notification may be the most reliable approach for an integrated warning-alarm system.

3. Depending on the purpose of monitoring (research, early-warning, both) and site characteristics (in particular accessibility and safety issues) different monitoring strategies should be designed. No single solution can be applied to all monitoring situations, and there are no standards or guidelines regarding the optimal set of sensors to install in a given basin. As a general rule, passive sensors (e.g., trip wires, geophones) or piezoelectric devices (e.g., load cells, pressure sensors) should be preferred for early-warning systems because they have very low power consumption, and power consumption is always an issue in long-term monitoring. Active sensors such as laser scanners or Doppler radar, on the other hand, may provide crucial data for understanding the dynamics of the flow although they require high computing power and large storage capacity on-site. In all cases, the "simpler is better" design philosophy has proven to work better in the harsh environmental conditions where debris-flow monitoring sites typically operate.

4. Eight of the nine systems include a differentiation between a "non-event mode" with a low sampling rate and the "event mode" characterised by high frequency sampling. The switch into "event mode" is determined by trip wires at one site, by a critical ground vibration at three sites, by a rainfall threshold at three sites and by a combination of these criteria at one site. Such a switch, and the correct definition of the thresholds, are essential points for an effective warning and alarm system, as well as for suitable characterizations of debris flow events. In addition, the differentiation also simplifies post-processing of the data and reduces storage memory requirements.

5. A fundamental point in every system is the adequate selection of sensors that should be installed. Regarding this issue, a distinction must be made between i) the assessment of debris-flow initiation conditions and ii) the detection and the characterisation of the moving flow. When dealing with initiation mechanisms, this review revealed that rain gauges are installed in each of the nine systems, while soil moisture or pore water pressure values are only deployed at four sites. Focussing on the detection and the characterisation of the debris flows, all nine systems use sensors to measure the flow stage and video/photo cameras to record flow characteristics. Ground vibration is recorded at eight sites. Other, more specific sensors that monitor shear stress, normal stress, surface velocity, or erosion are only utilised by some monitoring systems, but strongly aid in the understanding of the dynamic behaviour of debris flows. Infrasound and seismic sensors, which are installed hundreds of meters from the affected channel, have been shown to be useful for detecting and characterizing debris flows from a distance. Indeed, geophones and infrasound microphones are compact and low-cost sensors that allow the identification of different torrential processes and the main features of the debris flows such as the arrival-time of the main front, the presence of eventual subsequent surges, and the duration and the magnitude of the process. 
6. An important aspect of debris-flow monitoring is maintenance of the monitoring system, especially if monitoring is performed for warning purposes upstream of a specific vulnerable site. This task is generally very resource intensive and time consuming, as technical problems can occur due to multiple reasons from both natural and technical origins. Therefore, continuous control in the field of both the system and connected sensors is recommended. A remote-control system that can check the current status of the different sensors, the data acquisition and the power supply is very useful for identifying needed maintenance and is strongly encouraged. A status control of the monitoring system (e.g., every hour) via telemetry is mandatory for a successful performance of a warning and alarm system.

7. Redundancy in the measurements must be considered during the development of warning or alarm systems to anticipate a possible malfunctions and improve results. There are two types of redundancy: i) installing at least one more sensor than the minimum number of sensors needed for a specific goal (e.g., two geophones installed along the channel are enough for estimating the flow velocity, but more than two provide better results), ii) installing another type of sensor that can replace the one that is used for a specific goal (e.g., radar, laser or ultrasound devices for stage measurements; or warning based on a seismic algorithm can be progressively improved by comparisons with video footage).

8. An integrated risk mitigation strategy may also include structural countermeasures like retention basins or flow deflectors, apart from a warning and alarm system. This is of special importance when human settlements or essential infrastructures (e.g., highways or energy generation) are affected.

\section{Author contributions}

MH initiated and organized this review, elaborated the comparison plots and wrote most of the paper. MB strongly contributed to section 2 and corrected the other parts. $\mathrm{MH}, \mathrm{VC}, \mathrm{CB}$, and $\mathrm{MB}$ revised and discussed thoroughly the manuscript before the submission. All other authors delivered the description and data of their monitoring site and checked the final version of the paper.

\section{Acknowledgements}

The idea of this review started during EGU 2018 and since then many colleagues have contributed information. The authors want to thank to all the persons that helped in the design, installation and maintenance of the monitoring sites; in particular Jeffrey Coe, Jason Kean, and Scott McCoy (Chalk Cliffs), Peng Cui (Ergou), Pierpaolo Macconi, Marco Cavalli, Francesco Comiti, Massimo Arattano and Lorenzo Marchi (Gadria), Bruno Fritschi, Stefan Boss, Alexandre Badoux, Brian McArdell and Dieter Rickenmann (Illgraben), Hiroshi Suwa and Setsuo Okuda (Kamikamihori), Friedrich Zott (Lattenbach), Frédéric Liébault, Oldrich Navratil, Firmin Fontaine and Hervé Bellot (Réal), José Moya and Clàudia Abancó (Rebaixader) and Yi-Min Huang (Shenmu). Comments of Jason Kean (U.S. Geological Survey) on a previous version of the paper are greatly appreciated. SM acknowledges a grant of JSPS program for fostering globally talented researchers (G2901). The monitoring at Réal was supported by the SedAlp Project (reference number 1-4-3-AT, INTERREG Alpine Space Program). The monitoring at Gadria is supported by the Civil Protection Agency of the Autonomous Province of Bozen-Bolzano and by the EFRE-FESR project SEDIPLAN-r. The monitoring at Rebaixader was supported by the SMuCPhy project of the Spain Government (BIA 2015-67500-R) and by AEI/FEDER. Any use of trade, firm, or product names is for descriptive purposes only and does not imply endorsement by the U.S. Government. 


\section{References}

Abancó, C., Hürlimann, M., Fritschi, B., Graf, C., Moya, J., 2012. Transformation of Ground Vibration Signal for DebrisFlow Monitoring and Detection in Alarm Systems. Sensors 12, 4870-4891.

Abancó, C., Hürlimann, M., Moya, J., 2014. Analysis of the ground vibration generated by debris flows and other torrential processes at the Rebaixader monitoring site (Central Pyrenees, Spain). Nat. Hazards Earth Syst. Sci. 14, 929-943.

Abancó, C., Hürlimann, M., Moya, J., Berenguer, M., 2016. Critical rainfall conditions for the initiation of torrential flows. Results from the Rebaixader catchment (Central Pyrenees). J. Hydrol. 541, 218-229.

Allstadt, K.E., Matoza, R.S., Lockhart, A.B., Moran, S.C., Caplan-Auerbach, J., Haney, M.M., Thelen, W.A., Malone, S.D., 2018. Seismic and acoustic signatures of surficial mass movements at volcanoes. J. Volcanol. Geotherm. Res. 364, 76-106.

Antonello, G., Casagli, N., Farina, P., Leva, D., Nico, G., Sieber, A.J., Tarchi, D., 2004. Ground-based SAR interferometry for monitoring mass movements. Landslides. 1(1), 21-8.

Apostolov, A., Benoît, J., 2017. Motion Tracking “ Smart Rock” Device for the Study of Landslide and Debris Flow Mechanisms, in: 3rd North American Symposium on Landslides. Roanoke (USA), pp. 889-900.

Arai, M., Hübl, J., Kaitna, R., 2013. Occurrence conditions of roll waves for three grain-fluid models and comparison with results from experiments and field observation. Geophys. J. Int. 195, 1464-1480.

Arattano, M., Moia, F., 1999. Monitoring the propagation of a debris flow along a torrent. Hydrol. Sci. J. 44, 811-823.

Arattano, M., Marchi, L., 2005. Measurements of debris flow velocity through cross-correlation of instrumentation data. Nat. Hazards Earth Syst. Sci. 5, 137-142.

Arattano, M., Marchi, L., 2008. Systems and Sensors for Debris-flow Monitoring and Warning. Sensors 8, $2436-2452$.

Arattano, M., Abancó, C., Coviello, V., Hürlimann, M., 2014. Processing the ground vibration signal produced by debris flows: the methods of amplitude and impulses compared. Comput. Geosci. 73, 17-27.

Arattano, M., Coviello, V., Cavalli, M., Comiti, F., Macconi, P., Theule, J., Crema, S., 2015. Brief Communication: A new testing field for debris flow warning systems. Nat. Hazards Earth Syst. Sci. 15, 1545-1549.

Badoux, A., Graf, C., Rhyner, J., Kuntner, R., McArdell, B., 2009. A debris-flow alarm system for the Alpine Illgraben catchment: design and performance. Nat. Hazards 517-539.

Bardou, E., 2002. Methodologie de Diagnostic des laves torrentielles sur un bassin versant alpin. Lausanne, EPFL. doi:10.5075/epfl-thesis-2479

Bardou, E., Ancey, C., Bonnard, C., Vulliet, L., 2003. Classification of debris-flow deposits for hazard assessment in alpine areas, in: Rickenmann, D., Chen, C.-L. (Eds.), Debris-Flow Hazards Mitigation: Mechanics Prediction and Assessment. Millpress, Rotterdam, Davos (Switzerland), pp. 799-808.

Baum, R.L. and Godt, J.W., 2010. Early warning of rainfall-induced shallow landslides and debris flows in the USA. Landslides, 7(3):259-272.

Bautista, B.C., Bautista, M.L.P., Garcia, D.C., 1986. Seismic monitoring: A useful tool for mudflow detection at Mayon volcano, Albay, Philippines. Philippine Journal of Volcanology 3(2), 90-108.

Bel, C., 2017. Analysis of debris-flow occurrence in active catchments (French Alps) from field monitoring data, PhDthesis. Université Grenoble Alpes.

Bel, C., Liébault, F., Navratil, O., Eckert, N., Bellot, H., Fontaine, F., Laigle, D., 2017. Rainfall control of debris-flow triggering in the Réal Torrent, Southern French Prealps. Geomorphology 291, 17-32. 
Berenguer, M., Sempere-Torres, D., Hürlimann, M., 2015. Debris-flow forecasting at regional scale by combining susceptibility mapping and radar rainfall. Nat. Hazards Earth Syst. Sci. 15, 587-602

Berger, C., McArdell, B., Fritschi, B., Schlunegger, F., 2010. A novel method for measuring the timing of bed erosion during debris flows and floods. Water Resour. Res. 46, doi:10.1029/2009WR007993.

Berger, C., McArdell, B.W., Schlunegger, F., 2011. Direct measurement of channel erosion by debris flows, Illgraben, Switzerland. J. Geophys. Res. 116, F01002, doi:10.1029/2010JF001722.

Berti, M., Genevois, R., Simoni, A., Tecca, P.R., 1999. Field observations of a debris flow event in the Dolomites. Geomorphology 29, 265-274.

Berti, M., Genevois, R., La Husen, R., Simoni, A., Tecca, P.R., 2000. Debris flow monitoring in the Acquabona watershed on the Dolomites (Italian Alps). Phys. Chem. Earth 25, 707-715.

Berti, M., Simoni, A., 2005. Experimental evidences and numerical modelling of debris flow initiated by channel runoff. Landslides 2, 171-182.

Berti, M., Simoni, A., 2010. Field evidence of pore pressure diffusion in clayey soils prone to landsliding. J. Geophys. Res. 115, F03031. https://doi.org/10.1029/2009JF001463

Bertrand, M., Liébault, F., Piégay, H., 2013. Debris-flow susceptibility of upland catchments. Nat. Hazards 67, 497-511.

Bogaard, T.A., Greco, R., 2016. Landslide hydrology: from hydrology to pore pressure. Wiley Interdiscip. Rev. Water 3, $439-459$.

Bonnet-Staub I., 1998. Mécanismes d'initiation des laves torrentielles dans les Alpes françaises - Contribution à la maitrise du risque. PhD Thesis, Ecole des Mines de Paris. pp.237.

Bremer, M., Sass, O., 2012. Combining airborne and terrestrial laser scanning for quantifying erosion and deposition by a debris flow event. Geomorphology 138, 49-60.

Burtin, A., Hovius, N., Turowski, J.M., 2016. Seismic monitoring of torrential and fluvial processes. Earth Surf. Dyn. 4 , 285-307.

Capra, L., Coviello, V., Borselli, L., Márquez-Ramírez, V.-H., Arámbula-Mendoza, R., 2018. Hydrological control of large hurricane-induced lahars: evidence from rainfall-runoff modeling, seismic and video monitoring. Nat. Hazards Earth Syst. Sci. 18, 781-794.

Catani, F., Canuti, P., Casagli, N., 2014. The Use of Radar Interferometry in Landslide Monitoring, in: Shan, W., Guo, Y., Wang, F., Marui, H., Strom, A. (Eds.), Landslides in Cold Regions in the Context of Climate Change. Springer, pp. 177-190.

Chambers J., Meldrum P., Gunn D., Wilkinson P., Merritt A., Murphy W., West J., Kuras O., Haslam E., Hobbs P., Pennington C., Munro C., 2013. Geophysical-geotechnical sensor networks for landslide monitoring. Proceedings of the Second World Landslide Forum. Rome. 1-6.

Chang, S.Y., Lin, C.P., 2007. Debris flow detection using image processing techniques, in: Major, J.J., Chen, C. (Eds.), 4th Int. Conf. on Debris-Flow Hazards Mitigation. Millpress, Chengdu, China, pp. 549-560.

Cho, C.Y., Chou, P.H., Chung, Y.C., King, C.T., Tsai, M.J., Lee, B.J., Chou, T.Y., 2008. Wireless sensor networks for debris flow observation, in: 2008 5th Annual IEEE Communications Society Conference on Sensor, Mesh and Ad Hoc Communications and Networks, SECON. pp. 615-617.

Chou, H.T., Chang, Y.L., Zhang, S.C., 2010. Acoustic signals and geophone response induced by stony-type debris flows, in: Interpraevent. Taipei (Taiwan), pp. 712-720. 
Coe, J.A., Ellis, W.L., Godt, J.W., Savage, W.Z., Savage, J.E., Michael, J.A., Kibler, J.D., Powers, P.S., Lidke, D.J., Debray, S., 2003. Seasonal movement of the Slumgullion landslide determined from global positioning system surveys and field instrumentation, July 1998-March 2002. Eng. Geol. 68, 67-101.

Coe, J.A., Kinner, D.A., Godt, J.W., 2008. Initiation conditions for debris flows generated by runoff at Chalk Cliffs, central Colorado. Geomorphology 96, 270-297.

Coe, J.A., Kean, J.W., McCoy, S.W., Staley, D.M., Wasklewicz, T.A., 2010. Chalk Creek Valley: Colorado’s natural debris-flow laboratory, in: Morgan, L.., Quane, S. (Eds.), Through the Generations: Geologic and Anthropogenic Field Excursions in the Rocky Mountains from Modern to Ancient. Geological Society of America Field Guide 18, pp. 95117.

Cole, S.E., Cronin, S.J., Sherburn, S., Manville, V., 2009. Seismic signals of snow-slurry lahars in motion: 25 September 2007, Mt Ruapehu, New Zealand. Geophys. Res. Lett. 36, doi:10.1029/2009GL038030.

Comiti, F., Marchi, L., Macconi, P., Arattano, M., Bertoldi, G., Borga, M., Brardinoni, F., Cavalli, M., D’Agostino, V., Penna, D., Theule, J., 2014. A new monitoring station for debris flows in the European Alps: first observations in the Gadria basin. Nat. Hazards 73, 1175-1198.

Cook, K.L., 2017. An evaluation of the effectiveness of low-cost UAVs and structure from motion for geomorphic change detection. Geomorphology 278, 195-208.

Corominas, J., Moya, J., Ledesma, A., Lloret, A., Gili, J., 2005. Prediction of ground displacements and velocities from groundwater level changes at the Vallcebre landslide (Eastern Pyrenees, Spain). Landslides 2, 83-96.

Coviello, V., Arattano, M., Turconi, L., 2015. Detecting torrential processes from a distance with a seismic monitoring network. Nat. Hazards 78, 2055-2080.

Coviello, V., Capra, L., Vázquez, R., Márquez-Ramírez, V.H., 2018. Seismic characterization of hyperconcentrated flows in a volcanic environment. Earth Surf. Process. Landforms 43, 2219-2231.

Coviello V., Arattano M., Marchi L., Comiti F., Macconi P., 2019a. Seismic characterization of debris flows: insights into energy radiation and implications for warning. Journal of Geophysical Research - Earth Surface, doi:10.1029/2018JF004683.

Coviello, V., Theule, J.I., Marchi, L., Comiti, F., Crema, S., Cavalli, M., Arattano, M., Lucía, A., Macconi, P., $2019 b$. Deciphering sediment dynamics in a debris-flow catchment: insights from instrumental monitoring and highresolution topography, in: 7th International Conference on Debris-Flow Hazards Mitigation. Boulder, CO.

Crosta, G.B., Dal Negro, P., 2003. Observations and modelling of soil slip-debris flow initiation processes in pyroclastic deposits: the Sarno 1998 event. Nat. Hazards Earth Syst. Sci. 3, 53-69.

Cucchiaro, S., Cavalli, M., Vericat, D., Crema, S., Llena, M., Beinat, A., Marchi, L., Cazorzi, F., 2018. Monitoring topographic changes through 4D-structure-from-motion photogrammetry: application to a debris-flow channel. Environ. Earth Sci. 77, 632.

Cui, P., Chen, X., Waqng, Y., Hu, K., Li, Y., 2005. Jiangjia Ravine debris flows in south-western China, in: Jakob, M., Hungr, O. (Eds.), Debris-Flow Hazards and Related Phenomena. Springer, Berlin, pp. 565-594.

Cui, P., Guo, X., Yan, Y., Li, Y., Ge, Y., 2018. Real-time observation of an active debris flow watershed in the Wenchuan Earthquake area. Geomorphology 321, 153-166.

D’Agostino, V., Marchi, L., 2001. Debris flow magnitude in the Eastern Italian Alps: data collection and analysis. Phys. Chem. Earth, Part C Solar, Terr. Planet. Sci. 26, 657-663.

de Haas, T., Ventra, D., Carbonneau, P.E., Kleinhans, M.G., 2014. Debris-flow dominance of alluvial fans masked by runoff reworking and weathering. Geomorphology 217, 165-181. 
Frank, F., McArdell, B.W., Oggier, N., Baer, P., Christen, M., Vieli, A., 2017. Debris-flow modeling at Meretschibach and Bondasca catchments, Switzerland: sensitivity testing of field-data-based entrainment model. Nat. Hazards Earth Syst. Sci. 17, 801-815.

Galgaro, A., Tecca, P.R., Genevois, R., Deganutti, A.M., 2005. Acoustic module of the Acquabona (Italy) debris flow monitoring system. Nat. Hazards Earth Syst. Sci. 5, 211-215.

Geologische Bundesanstalt, 2010. Geological map 1:50.000, Blatt 144 Landeck. Wien, Austria.

Global Volcanism Program, 2013. Volcanoes of the World, v. 4.8.1. Venzke, E (ed.). Smithsonian Institution. Downloaded 05 Aug 2019. https://doi.org/10.5479/si.GVP.VOTW4-2013

Godt, J.W., Baum, R.L., Lu, N., 2009. Landsliding in partially saturated materials. Geophys. Res. Lett. 36, L02403, doi:10.1029/2008GL035996.

Gonda, Y., 2009. Function of a debris flow breaker. Int. J. Eros. Control Eng. 2(1), 15-21.

Graf, C., Badoux, A., McArdell, B., Collet, M., Boss, S., Huguenin, P., 2018. Erneuerung Murgangwaage im Illgraben. FAN Agenda, 2, 5-9.

Gregoretti, C., Degetto, M., Bernard, M., Crucil, G., Pimazzoni, A., De Vido, G., Berti, M., Simoni, A., Lanzoni, S., 2016. Runoff of small rocky headwater catchments: Field observations and hydrological modeling. Water Resour. Res. 52, 8138-8158.

Guo, X., Cui, P., Li, Y., Zou, Q., Kong, Y., 2016a. The formation and development of debris flows in large watersheds after the 2008 Wenchuan Earthquake. Landslides 13, 25-37.

Guo, X.J., Cui, P., Li, Y.,Ma, L., Ge, Y.G.,William, B.M., 2016b. Intensity-duration threshold of rainfall triggering debris flows inWenchuan earthquake area, China. Geomorphology 263, 208-216.

Habib, E., Krajewski, W.., Kruger, A., 2001. Sampling errors of tipping-bucket rain gauge measurements. J. Hydrol. Eng. 6, 159-166.

Habler, G., Thöni, M., Grasemann, B., 2009. Cretaceous metamorphism in the Austroalpine Matsch Unit (Eastern Alps): The interrelation between deformation and chemical equilibration processes. Mineral. Petrol. 97, 149-171.

Hikida, M., Moriyama, M., Nagai, Y., 2007. Warning system for debris flow hazards at Sakurajima Volcano, Japan, in: International Conference on Debris-Flow Hazards Mitigation: Mechanics, Prediction, and Assessment, Proceedings. Chengdu, pp. 593-602.

Hu, K., Wei, F., Li, Y., 2011. Real-time measurement and preliminary analysis of debris-flow impact force at Jiangjia Ravine, China. Earth Surf. Process. Landforms 36, 1268-1278. https://doi.org/10.1002/esp.2155

Huang, C.J., Yin, H.Y., Chen, C.Y., Yeh, C.H., Wang, C.L., 2007. Ground vibrations pdoduced by rock motions and debris flows. J. Geophys. Res. 112, F02014.

Huang, Y.M., Chen, W.C., Fang, Y.M., Lee, B.J., Chou, T.Y., Yin, H.., 2013. Debris Flow Monitoring - A Case Study of Shenmu Area in Taiwan. Disasters Adv. 6, 1-9.

Huang, Y.M., Chu, C.R., Fang, Y.M., Tsai, M.C., Lee, B.J., Chou, T.Y., Lee, C.Y., Chen, C.Y., Yin, H.Y., 2016. Characteristics of debris flow vibration signals in Shenmu, Taiwan, in: Interpraevent International Symposium 2016, Lucerne, Switzerland, pp. 306-318.

Huang, Y.M., Fang, Y.., Chou, T.,, Lee, C.., Yin, H.., 2017. The Vibration Signal Analysis of Debris Flow in Taiwan, in: 5th International Conference on Geotechnical Engineering for Disaster Mitigation and Rehabilitation. Taipei, Taiwan, pp. 13-14.

Hübl, J., Ganahl, E., Gruber, H., Holub, M., Holzinger, G., Moser, M., Pichler, A., 2004. Risikomanagement Lattenbach: Risikoanalyse, IAN Report 95, Institute of Mountain Risk engineering, BOKU, Vienna (unpublished report in 
German).

https://boku.ac.at/fileadmin/data/H03000/H87000/H87100/DAN_IAN_Reports/Rep095_-

1Risikoanalyse.pdf

Hübl, J., Suda, J., Proske, D., Kaitna, R., Scheidl, C., 2009. Debris flow impact estimation, in: Popovska, C., Jovanovski,

M. (Eds.), 11th Symposium on Water Management and Hydraulic Engineering. Ohrid, Macedonia, pp. 137-148.

Hübl, J., Kaitna, R., 2010. Sediment delivery from the Lattenbach catchment by debris floods and debris flows, in: EGU General Assembly. p. 10585.

Hübl J., Beck M., Zöchling, M., Moser M., Kienberger, C., Jenner, A., Forstlechner, D., 2016. Ereignisdokumentation 2015. IAN Report 175. Institute of Mountain Risk engineering, BOKU, Vienna (unpublished report in German). https://boku.ac.at/fileadmin/data/H03000/H87000/H87100/DAN_IAN_Reports/Rep175_1Band Ereignisdoku2015.pdf

Hübl, J., Mikoš, M., 2018. Practice Guidelines on Monitoring and Warning Technology for Debris Flows, in: Sassa, K., Guzzetti, F., Yamagishi, H., Arbanas, Ž., Casagli, N., McSaveney, M., Dang, K. (Eds.), Landslide Dynamics: ISDRICL Landslide Interactive Teaching Tools. Springer Nature, pp. 567-585.

Hübl, J., Schimmel, A., Koschuch, R., 2018. Evaluation of Different Methods for Debris Flow Velocity Measurements at the Lattenbach Creek, in: INTERPRAEVENT 2018. Toyama, Japan, Japan, pp. 2-8.

Hungr, O., Evans, S.G., Bovis, M.J., Hutchinson, J.N., 2001. A review of the classification of landslides of the flow type. Environ. Eng. Geosci. 7, 221-238.

Hungr, O., Leroueil, S., Picarelli, L., 2014. The Varnes classification of landslide types, an update. Landslides 11, 167194.

Hürlimann, M., Rickenmann, D., Graf, C., 2003. Field and monitoring data of debris-flow events in the Swiss Alps. Can. Geotech. J. 40, 161-175.

Hürlimann, M., Abancó, C., Moya, J., 2010. Debris-flow initiation affected by snowmelt. Case study of the Senet monitoring site, Eastern Pyrenees, in: Mountain Risks: Bringing Science to Society. Florence, Italy, pp. 81-86.

Hürlimann, M., Abancó, C., Moya, J., 2012. Rockfalls detached from a lateral moraine during spring season. 2010 and 2011 events observed at the Rebaixader debris-flow monitoring site (Central Pyrenees, Spain). Landslides 385-393.

Hürlimann, M., Abancó, C., Moya, J., Vilajosana, I., 2014. Results and experiences gathered at the Rebaixader debrisflow monitoring site, Central Pyrenees, Spain. Landslides 11, 939-953. https://doi.org/10.1007/s10346-013-0452-y

Hürlimann, M., Oorthuis, R., Abancó, C., Carleo, L., Moya, J., 2019. Monitoring of rainfall and infiltration at the Rebaixader catchment (Central Pyrenees), in: 7th International Conference on Debris-Flow Hazards Mitigation. Boulder, CO.

Ikeda, A., Hara Y, 2003. Flow properties of debris flows on the Kitamata Valley of the Name River, Japan, in: DebrisFlow Hazards Mitigation: Mechanics Prediction and Assessment. Millpress, pp. 851-862.

Imaizumi, F., Tsuchiya, S., Ohsaka, O., 2005. Behaviour of debris flows located in a mountainous torrent on the Ohya landslide, Japan. Can. Geotech. J. 42, 919-931.

Itakura, Y., Fujii, N., Sawada, T., 2000. Basic characteristics of ground vibration sensors for the detection of debris flow. Phys. Chem. Earth, Part B 25, 717-720.

Itakura, Y., Inaba, H., Sawada, T., 2005. A debris-flow monitoring devices and methods bibliography. Nat. Hazards Earth Syst. Sci. 5, 971-977.

Iverson, R.M., 1997. The physics of debris flows. Rev. Geophys. 35, 245-296.

Iverson, R.M., Reid, M.E., LaHusen, R.G., 1997. Debris-flow mobilization from landslides. Annu. Rev. Earth Planet. Sci. $25,85-138$. 
Iverson, R.M., Logan, M., LaHusen, R.G., Berti, M., 2010. The perfect debris flow? Aggregated results from 28 largescale experiments. J. Geophys. Res. 115. doi.org/doi:10.1029/2009JF001514

Iverson, R.M., Reid, M.E., Logan, M., LaHusen, R.G., Godt, J.W., Griswold, J.P., 2011. Positive feedback and momentum growth during debris-flow entrainment of wet bed sediment. Nat. Geosci. 4, 116-121.

Jacquemart, M., Meier, L., Graf, C., Morsdorf, F., 2017. 3D dynamics of debris flows quantified at sub-second intervals from laser profiles. Nat. Hazards 89, 785-800.

Jakob, M., 2005. A size classification for debris flows. Eng. Geol. 79, 151-161.

Jakob, M., Hungr, O., 2005. Debris-flow Hazards and Related Phenomena. Springer, Berlin. pp.739.

Jan, C.D., Lee, M.H., Huang, T.H., 2003. Effect of Rainfall on Debris Flows in Taiwan, in: Proceedings of the International Conference on Slope Engineering. Hong Kong, pp. 741-751.

Kean, J.W., Staley, D.M. and Cannon, S.H.. 2011. In situ measurements of post-fire debris flows in southern California: Comparisons of the timing and magnitude of 24 debris-flow events with rainfall and soil moisture conditions, J. Geophys. Res., 116(F4), F04019, doi:10.1029/2011jf002005.

Kean, J.W., McCoy, S.W., Tucker, G.E., Staley, D.M., Coe, J.A., 2013. Runoff-generated debris flows: Observations and modeling of surge initiation, magnitude, and frequency. J. Geophys. Res. Earth Surf. 118. doi:10.1002/jgrf.20148

Kean, J.W., Coe, J.A., Coviello, V., Smith, J.B., McCoy, S.W., Arattano, M., 2015. Estimating rates of debris flow entrainment from ground vibrations. Geophys. Res. Lett. 42, 6365-6372.

Kogelnig, A., Hübl, J., Suriñach, E., Vilajosana, I., McArdell, B., 2014. Infrasound produced by debris flow: propagation and frequency content evolution. Nat. Hazards 70, 1713-1733.

Kumagai, H., Palacios, P., Maeda, T., Castillo, D.B., Nakano, M., 2009. Seismic tracking of lahars using tremor signals. J. Volcanol. Geotherm. Res. 183, 112-121.

LaHusen, R., 2005. Debris-flow instrumentation, in: Jakob, M., Hungr, O. (Eds.), Debris-Flow Hazards and Related Phenomena. Springer, Berlin, pp. 291-304.

Lai, V.H., Tsai, V.C., Lamb, M.P., Ulizio, T.P., Beer, A.R., 2018. The Seismic Signature of Debris Flows: Flow Mechanics and Early Warning at Montecito, California. Geophys. Res. Lett. 45, 5528-5535.

Lavigne, F., Thouret, J.C., Voight, B., Young, K., LaHusen, R., Marso, J., Suwa, H., Sumaryono, A., Sayudi, D.S., Dejean, M., 2000. Instrumental lahar monitoring at Merapi Volcano, Central Java, Indonesia. J. Volcanol. Geotherm. Res. Jul 100, 457-478.

Lee, H.C., Banerjee, A., Fang, Y.M., Lee, B.J., King, C.T., 2010. Design of a multifunctional wireless sensor for in-situ monitoring of debris flows. IEEE Trans. Instrum. Meas. 59, 2958-2967.

Lei, T.., Huang, Y.M., Lee, B.J., Hsieh, M.., Lin, K.., 2014. Development of an Empirical Model for Rainfall-induced Hillside Vulnerability Assessment- A Case Study on Chen-Yu-Lan Watershed, Nantou, Taiwan. Nat. Hazards 74, $341-373$.

Liébault, F., Passalacqua, O., Bel, C., 2015. Sediment yield assessment of a debris-flow torrent from sequential highresolution DEMs, in: SedAlp Project Report: Guidelines for Assessing Sediment Dynamics in Alpine Basins and Channel Reaches - WP4 Basin-Scale Sediment Dynamics, Annex. pp. 55-63.

Lin, C.-W., Liu, S.-H., Lee, S.-Y., Liu, C.-C., 2006. Impacts of the Chi-Chi earthquake on subsequent rainfall-induced landslides in central Taiwan. Eng. Geol. 86, 87-101.

Magno M., Brunelli D., Giuffrida R., Leonardi S., Benini L., 2014. A portable hybrid hydrogen fuel cell-battery power unit for wireless sensor network. International Symposium on Power Electronics, Electrical Drives, Automation and Motion (SPEEDAM 2014): 1-6. 
Major, J.J., Bertin, D., Pierson, T.C., Amigo, Á., Iroumé, A., Ulloa, H., Castro, J., 2016. Extraordinary sediment delivery and rapid geomorphic response following the 2008-2009 eruption of Chaitén Volcano, Chile, Water Resour. Res., 52, doi:10.1002/2015WR018250.

Marchi, L., Arattano, M., Deganutti, A.M., 2002. Ten years of debris-flow monitoring in the Moscardo Torrent (Italian Alps). Geomorphology 46, 1-17.

Marchi, L., Brunetti, M.T., Cavalli, M., Crema, S., 2018. Debris-flow volumes in northeastern Italy: Relationship with drainage area and size probability. Earth Surf. Process. Landforms. https://doi.org/10.1002/esp.4546.

Marchi, L., Coviello, V., Comiti, F., Crema, S., Cavalli, M., Macconi, P., 2019. Rainfall threshold for debris flow occurrence in the Gadria catchment, eastern Italian Alps. Geophys. Res. Abstr. EGU2019-7188.

Marcial, S., Melosantos, A.A., Hadley, K.C., LaHusen, R.G., Marso, J.N., 1996. Instrumental lahar monitoring at Mount Pinatubo. in: Newhall, C.G., Punongbayan, R.S. (Eds) Fire and mud: eruptions and lahars of Mount Pinatubo, Philippines. Washington Press, Seattle, pp. 1015-1022.

Marra, F., Nikolopoulos, E.I., Creutin, J.D., Borga, M., 2014. Radar rainfall estimation for the identification of debrisflow occurrence thresholds. J. Hydrol. 519, Part, 1607-1619.

Marra, F., Nikolopoulos, E.I., Creutin, J.D., Borga, M., 2016. Space-time organization of debris flows-triggering rainfall and its effect on the identification of the rainfall threshold relationship. J. Hydrol. 541, 246-255.

McArdell, B., Badoux, A., 2007. Influence of rainfall on the initiation of debris flows at the Illgraben catchment, canton of Valais, Switzerland. Geophys. Res. Abstr. 9, 8804.

McArdell, B., Bartelt, P., Kowalski, J., 2007. Field observations of basal forces and fluid pore pressure in a debris flow. Geophys. Res. Lett. 34, doi:10.1029/2006GL029183.

McArdell, B.W., 2016. Field Measurements of Forces in Debris Flows at the Illgraben : Implications for Channel-Bed Erosion. Int. J. Eros. Control Eng. 9, 194-198.

McCoy, S.W., Kean, J.W., Coe, J.A., Staley, D.M., Wasklewicz, T.A., Tucker, G.E., 2010. Evolution of a natural debris flow: In situ measurements of flow dynamics, video imagery, and terrestrial laser scanning. Geology 38, $735-738$.

McCoy, S.W., Coe, J.A., Kean, J.W., Tucker, G.E., Staley, D.M., Wasklewicz, T.A., 2011. Observations of debris flows at Chalk Cliffs, Colorado, USA: Part 1, in situ measurements of flow dynamics, tracer particle movement and video imagery from the summer of 2009. Ital. J. Eng. Geol. Environ. 65-75. doi:10.4408/IJEGE.2011-03.B-078.

McCoy, S.W., Kean, J.W., Coe, J.A., Tucker, G.E., Staley, D.M., Wasklewicz, T.A., 2012. Sediment entrainment by debris flows: In situ measurements from the headwaters of a steep catchment. J. Geophys. Res. 117, F03016.

McCoy, S.W., Tucker, G.E., Kean, J.W., Coe, J.A., 2013. Field measurement of basal forces generated by erosive debris flows. J. Geophys. Res. Earth Surf. 118, 589-602.

Michelson, D.B., 2004. Systematic correction of precipitation gauge observations using analyzed meteorological variables. J. Hydrol. 290, 161-177.

Miller, M.., 1999. Active breaching of a geometric segment boundary in the Sawatch Range normal fault, Colorado, USA. J. Struct. Geol. 21, 769-776.

Mostbauer, K., Kaitna, R., Prenner, D., Hrachowitz, M., 2018. The temporally varying roles of rainfall, snowmelt and soil moisture for debris flow initiation in a snow-dominated system. Hydrol. Earth Syst. Sci. 22, 3493-3513.

Muñoz, A., 1992. Evolution of a continental collision belt: ECORS-Pyrenees crustal balanced cross-section, in: McClay, K.R. (Ed.), Thrust Tectonics. Chapman \& Hall, pp. 235-246. 
Nagl, G., Hübl, J., 2017. A Check-Dam to Measure Debris Flow-Structure Interactions in the Gadria Torrent, in: Mikoš, M., Vilímek, V., Yin, Y., Sassa, K. (Eds.), Advancing Culture of Living with Landslides. Springer International Publishing, Cham, pp. 465-471.

Nagl, G., Kaitna, R., Hübl, J., 2018. A monitoring barrier for investigating debris flow/structure/ground interactions. 5th Int. Conf. Debris Flows Disasters, Risk, Forecast. Prot. 152-157.

Navratil, O., Liébault, F., Bellot, H., Theule, J., Travaglini, E., Ravanat, X., Ousset, F., Laigle, D., Segel, V., Fiquet, M. High-Frequency Monitoring of Debris-Flows in the French Alps. 2012. In: Proc. 12th Congress INTERPRAEVENT; Grenoble, France.

Navratil, O., Liébault, F., Bellot, H., Travaglini, E., Theule, J., Chambon, G., Laigle, D., 2013. High-frequency monitoring of debris-flow propagation along the Réal Torrent, Southern French Prealps. Geomorphology 201, 157-171.

Nikolopoulos, E.I., Crema, S., Marchi, L., Marra, F., Guzzetti, F., Borga, M., 2014. Impact of uncertainty in rainfall estimation on the identification of rainfall thresholds for debris flow occurrence. Geomorphology 221, $286-297$.

Nuñez-Andrés, M.A., Buill, F., Hürlimann, M., Abancó, C., 2019. Multi-temporal analysis of morphologic changes applying geomatic techniques. 70 years of torrential activity in the Rebaixader catchment (Central Pyrenees). Geomatics, Nat. hazards risk 10, 314-335.

Ohmi, S., 2016. Relation of debris flow around the Yake-dake volcano and Kamikamihori area, central Japan, using ground motion data recorded by seismometers. Annuals of Disaster Prevention Research Institute, Kyoto University. 59B, 48-56. (in Japanese with English abstract)

Okano, K., Suwa, H., Kannno, T., 2012. Characterization of debris flows by rainstorm condition at a torrent on the Mount Yakedake volcano, Japan. Geomorphology. 136, 88-94.

Okuda, S., Suwa, H., Nakano, M., Yokoyama, K., 1976. Synthetic observation on debris flow - Part 2. Observation at the eastern slope of Mt. Yakedake in 1975. Disaster Prevention Research Institute Annuals.19B, 385-402. (in Japanese with English abstract).

Osaka, T., Utsunomiya, R., Tagata, S., Ito, T., Mizuyama, T., 2014. Debris flow monitoring using load cells in Sakurajima Island, in: Interpraevent. pp. 107-116.

Palau, R.M., Hürlimann, M., Pinyol, J., Moya, J., Victoriano, A., Génova, M., Puig, C., 2017. Recent debris-flows in the Portainé catchment (Eastern Pyrenees, Spain). Analysis of monitoring and field data focussing on the 2015 event. Landslides 14, 1161-1170.

Pierson, T.C., 1986. Flow behavior of channelized debris flows, Mount St. Helens, Washington, in: Abraham, A.D. (Ed.), Hillslope Processes, The Binghamton Symp. in Geomorphology. Allen \& Unwin, Boston, pp. 269-296.

Reid, M.E., LaHusen, R.G., Iverson, R.M., 1997. Debris-flow initiation experiments using diverse hydrologic triggers, in Chen, C. (Ed.), $1^{\text {st }}$ Int. Conf. on Debris-Flow Hazards Mitigation, San Francisco (USA), pp.1-11.

Rickenmann, D., 1999. Empirical relationships for debris flows. Natural hazards, 19(1), 47-77.

Rickenmann, D., Laigle, D., McArdell, B., Hübl, J., 2006. Comparison of 2D debris-flow simulation models with field events. Comput. Geosci. 10, 241-264.

Rulli, M.C., Meneguzzo, F., Rosso, R., 2007. Wind control of storm-triggered shallow landslides. Geophys. Res. Lett. 34. doi:10.1029/2006GL028613

Savage, W.Z., Baum, R.L., 2005. Instability of steep slopes, in: Jakob, M., Hungr, O. (Eds.), Debris-Flow Hazards and Related Phenomena. Springer, pp. 53-79.

Schimmel, A., Hübl, J., 2016. Automatic detection of debris flows and debris floods based on a combination of infrasound and seismic signals. Landslides 13, 1181-1196. 
Schimmel, A., Hübl, J., McArdell, B.W., Walter, F., 2018. Automatic Identification of Alpine Mass Movements by a Combination of Seismic and Infrasound Sensors. Sensors 18(5). doi:10.3390/s18051658.

Schlunegger, F., Badoux, A., McArdell, B.W., Gwerder, C., Schnydrig, D., Rieke-Zapp, D., Molnar, P., 2009. Limits of sediment transfer in an alpine debris-flow catchment, Illgraben, Switzerland. Quat. Sci. Rev. 28, 1097-1105.

Scotton, P., Genevois, R., Moro, F., Zorzi, L., Girardi, G., Praticelli, N., 2011. The debris-flows monitoring system of acquabona torrent (Cortina d'Ampezzo, Belluno, Italy), in: Genevois, R., Hamilton, D., Prestininzi, A. (Eds.), 5 th Int. Conf. on Debris-Flow Hazards Mitigation. Padua, pp. 595-603.

Segoni, S., Lagomarsino, D., Fanti, R., Moretti, S., Casagli, N. 2015. Integration of rainfall thresholds and susceptibility maps in the Emilia Romagna (Italy) regional-scale landslide warning system. Landslides, 12(4):773-785.

Sherburn, S., Bryan, C.J. 1999. The Eruption Detection System: Mt. Ruapehu, New Zealand. Seismological Research Letters. 70(5), 505-511.

Smith, J.B., Kean, J.W., 2018. Long-Term Soil-Water Tension Measurements in Semiarid Environments: A Method for Automated Tensiometer Refilling. Vadose Zo. J. 17, 180070. Doi:10.2136/vzj2018.04.0070.

Spreafico, M., Weingartner, R., 2005. The Hydrology of Switzerland - Selected aspects and results. FOWG Reports. Water Series no. 7. Berne.

Staley, D.M., Wasklewicz, T.A., Coe, J.A., Kean, J.W., McCoy, S.W., Tucker, G.E., 2011. Observations of debris flows at Chalk Cliffs, Colorado, USA: Part 2, Changes in surface morphometery from terrestrial laser scanning in the summer of 2009, in: Debris-Flow Hazards Mitigation: Mechanics Prediction and Assessment. pp. 65-75.

Suwa, H., 1989. Field observation of debris flow, in: Proceedings of the Japan-China (Taipei) Joint Seminar on Natural Hazard Mitigation. Kyoto, Japan, pp. 343-352.

Suwa, H., 1992. Observation of debris flow. Int. J. Eros. Control Eng. 45, 43-51.

Suwa, H., Yamakoshi, T., Sato, K., 2000. Relationship between debris-flow discharge and ground vibration, in: Wieczorek, G.F., Naeser, N.D. (Eds.), 2nd International Conference on Debris-Flow Hazards Mitigation. Balkema, Taipei, pp. 311-318.

Suwa, H., Okano, K., Kanno, T., 2009. Behavior of debris flows monitored on test slopes of Kamikamihorizawa Creek, Mount Yakedake, Japan. Int. J. Eros. Control Eng. 2, 33-45.

Suwa, H., Okano, K., Kanno, T., 2011. Forty years of debris-flow monitoring at Kamikamihorizawa Creek, Mount Yakedake, in: Genevois, R., Hamilton, D.L., Prestininzi, A. (Eds.), 5th International Conference on Debris-Flow Hazards Mitigation. Padua, pp. 605-613.

Syarifuddin, M., Oishi, S., Legono, D., Hapsari, R.I., Iguchi, M., 2017. Integrating X-MP radar data to estimate rainfall induced debris flow in the Merapi volcanic area. Adv. Water Resour. 110, 249-262.

Takahashi, T., 2019. Debris Flow: Mechanics, Prediction and Countermeasures, 2nd edition. CRC Press/Balkema.

Takeshi, T., 2011. Evolution of Debris-flow Monitoring Methods on Sakurajima. Int. J. Eros. Control Eng. 4, $21-31$.

Theule, J.I., Liébault, F., Loye, A., Laigle, D., Jaboyedoff, M., 2012. Sediment budget monitoring of debris-flow and bedload transport in the Manival Torrent, SE France. Nat. Hazards Earth Syst. Sci. 12, 731-749.

Theule, J.I., Liébault, F., Laigle, D., Loye, A., Jaboyedoff, M., 2015. Channel scour and fill by debris flows and bedload transport. Geomorphology 243, 92-105.

Theule, J.I., Crema, S., Marchi, L., Cavalli, M., Comiti, F., 2018. Exploiting LSPIV to assess debris-flow velocities in the field. Nat. Hazards Earth Syst. Sci. 18, 1-13.

Tobler, D., Kull, I., Jacquemart, M., Haehlen, N., 2014. Hazard Management in a Debris Flow Affected Area: Case Study from Spreitgraben, Switzerland, in: World Landslide Forum 3. pp. 25-30. 
Tsai, M.., Huang, Y.M., Fang, Y.., Lee, B.J., Chou, T.Y., Yin, H.., 2014. Characteristics of Debris Flow in Taiwan - A Case Study in Shenmu Area, in: Interpraevent International Symposium. Nara, Japan, pp. 117-125.

Underwood, S.J., Schultz, M.D., Berti, M., Gregoretti, C., Simoni, A., Mote, T.L., Saylor, A.M., 2016. Atmospheric circulation patterns, cloud-to-ground lightning, and locally intense convective rainfall associated with debris flow initiation in the Dolomite Alps of northeastern Italy. Nat. Hazards Earth Syst. Sci. 16, 509-528.

Vagnon, F., Pirulli, M., Yague, A., Pastor, M., 2018. Comparison of two depth averaged numerical models for debris flow runout estimation. Can. Geotech. J. doi:10.1139/cgj-2017-0455

Vázquez, R., Capra, L., Coviello, V., 2016. Factors controlling erosion/deposition phenomena related to lahars at Volcán de Colima, Mexico, Nat. Hazards Earth Syst. Sci., 16, 1881-1895.

Walter, F., Burtin, A., McArdell, B.W., Hovius, N., Weder, B., Turowski, J.M., 2017. Testing seismic amplitude source location for fast debris-flow detection at Illgraben, Switzerland. Nat. Hazards Earth Syst. Sci. 17, 939-955.

Wei, S.C., Liu, K.F., Huang, Y.M., Fang, Y.M., Yin, H.Y., Huang, H.Y., Lin, C.L., 2018. Characteristics and Warning Methods of Ground Vibrations Generated by Debris Flows at Ai-Yu-Zi Creek. J. Chinese Soil Water Conserv. 49, 77-88.

Wendeler, C., Volkwein, A., Roth, A., Denk, M., Wartmann, S., 2007. Field measurements and numerical modelling of flexible debris flow barriers., in: Debris-Flow Hazards Mitigation: Mechanics Prediction and Assessment. pp. 681687.

Wendeler, C., Volkwein, A., McArdell, B.W., Bartelt, P., 2018. Load model for designing flexible steel barriers for debris flow mitigation. Can. Geotech. J. 39. Doi:10.1139/cgj-2016-0157.

Wieczorek, G.F., Glade, T., 2005. Climatic factors influencing occurrence of debris flow, in: Jakob, M., Hungr, O. (Eds.), Debris-Flow Hazards and Related Phenomena. Springer, Berlin, pp. 325-362.

Wieser, R., 2004. Die geologischen Verhältnisse am Südrand der Lechtaler Alpenzwischen Stanz und der Dawinalm: (Stanzertal, Nordtirol); unter besonderer Berücksichtigung der Massenbewegungen, Diploma thesis. Universität Innsbruck.

Wilford, D.J., Sakals, M.E., Innes, J.L., Sidle, R.C., Bergerud, W.A., 2004. Recognition of debris flow, debris flood and flood hazard through watershed morphometrics. Landslides 1, 61-66.

Worni, R., Huggel, C., Stoffel, M., and Pulgarín, B., 2012. Challenges of modeling current very large lahars at Nevado del Huila Volcano, Colombia, Bull. Volcanol., 74, 309-324.

Yamakoshi, T., Mizuyama, T., Suwa, H., Okunishi, K., Nakano, M., 2001. A two-decade hydrologic change at the source area of Kamikamihori Gully, Mount Yakedake. Int. J. Eros. Control Eng. 54, 22-32.

Yin, H.Y., Huang, C.J., Chen, C.Y., Fang, Y.M., Lee, B.J., Chou, T.Y., 2011. The present development of debris flow monitoring technology in Taiwan - A case study presentation, in: Genevois, R., Hamilton, D., Prestininzi, A. (Eds.), 5th Int. Conf. on Debris-Flow Hazards Mitigation. Padua, pp. 623-631.

Zhang, S., 1993. A comprehensive approach to the observation and prevention of debris flows in China. Nat. Hazards 7 , $1-23$.

Zhang, S., Hong, Y., Yu, B., 2004. Detecting infrasound emission of debris flow for warning purposes, in: Interpraevent. Riva/Trient, Italy, pp. 359-364. 